||||||||||||||||||||

(1)

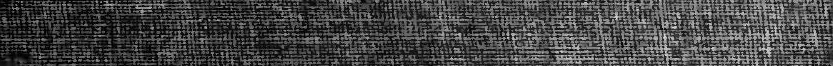
1) 6.

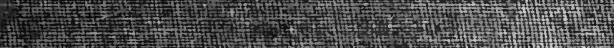
(1) (2) 18

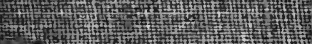

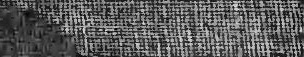
19. 47 (1) 3.12)

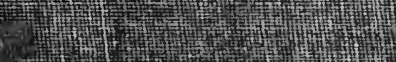
(5) (17) Xit

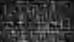

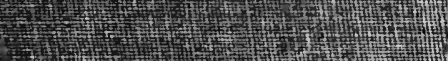

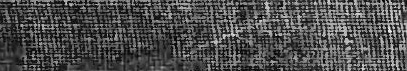
30

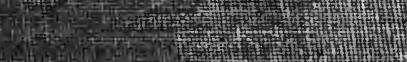
2. (1) Hin C) Whit 3 10. Fing Fing

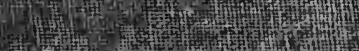
Than 6. (1) (4) A

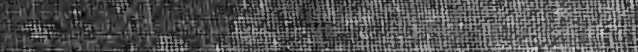
1947) + Pand Th 19.

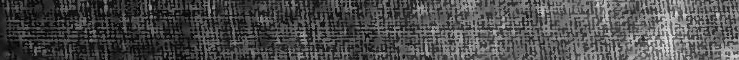
If 


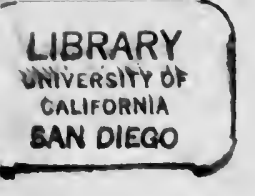

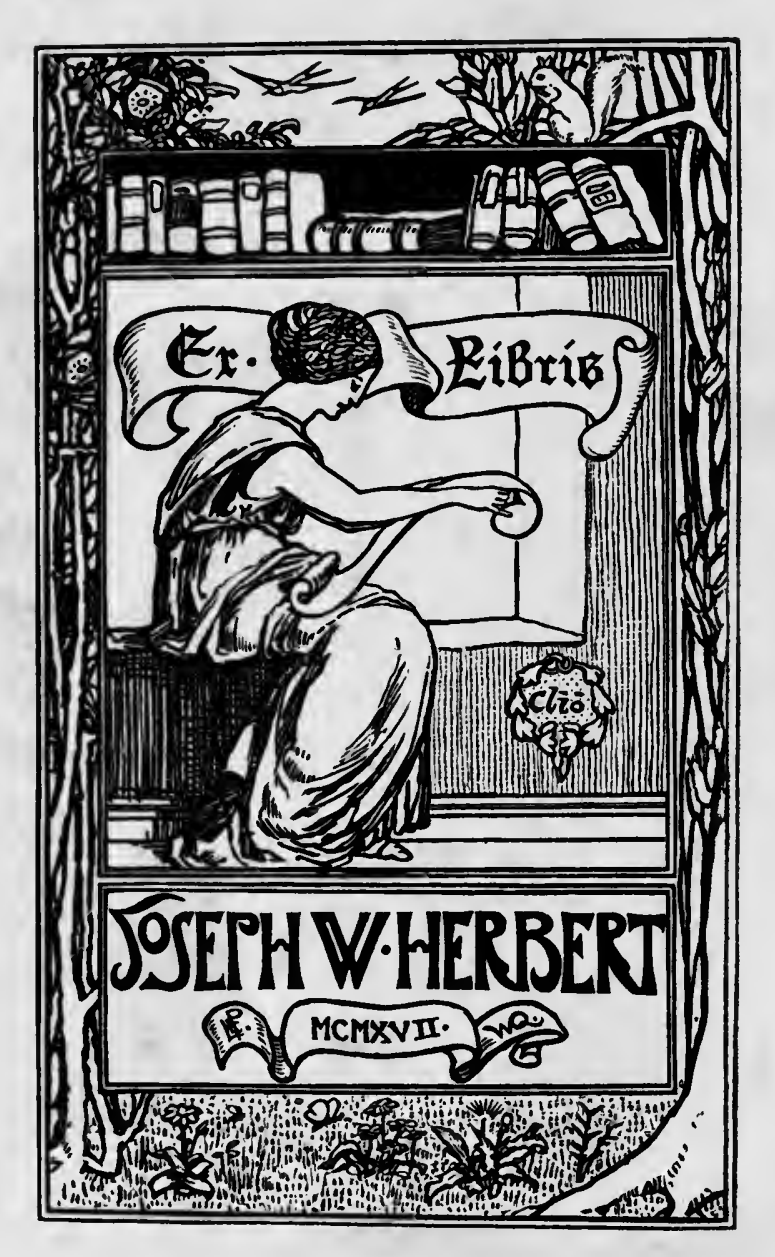




\section{Social Sciences \& Humanities Library}

University of California, San Diego

Please Note: This item is subject to recall.

\section{Date Due}

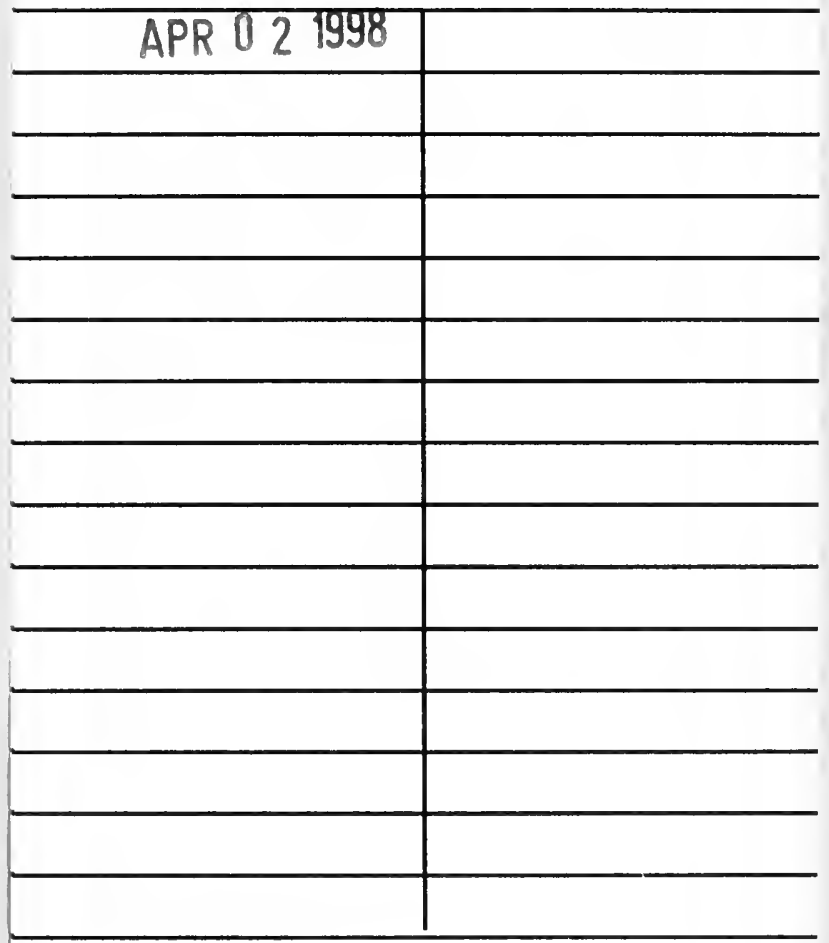




\section{Digitized by the Internet Archive in 2007 with funding from Microsoft Corporation}


STUDIES IN

THE TEACHING OF HISTORY 
BY THE SAME AUTHOR.

THE GREAT DIDACTIC OF JOHN AMOS COMENIUS

Translated into English and edited with biographical, historical, and crirical Introductions. 2ndEaition. Large Cr. 8vo. Cloth. 7s. 6d.net. Or in two Parts.

PART 1. Introductions. 38. 6d. net. PART II. Text. \$8, 6d. net.

Times.-" Mr. Keatinge's Translation of the 'Great Didactic' is vigorously executed; his biography of its author is at once copious, judicious, and sympathetic, and his sketch of the history of education and of Comenius's place in it is eminently scholarly and instructive."

\section{SUGGESTION IN EDUCATION}

and Edition. Large Cr. 8vo. Cloth. 4 s. 6d. net.

Education.- "We regard Mr. Keatinge's work as one of the most valuable contributions to educational science which have been published during recent years. . . . It is a fascinating work, calculated to interest the thoughtful parent as well as the professional reader."

ALSO JOINTLY WITH N. L. FRAZER, M.A.

\section{A HISTORY OF ENGLAND FOR SCHOOLS \\ WITH DOCUMENTS, PROBLEMS, AND EXERCISES}

and Edition. Large Crown 8vo. Illustrated with Maps and Plans. Cloth. $5 \mathbf{s}$.

Or in two separate volumes.

Part I. (55 B.c. to A.D. I603).

Part II. (I603 to Present Day).

2s. 6d. each.

This bistory has been compiled to meet the growing demand on the part of teachers for a book of practi. cable size, covering the whole of English history, and containing, in addition to a succinct narrative of the course of events, a sufficient number of contemporary documents to make it a laboratory manual for the pupil. Especial attention has been given to the problems and exercises on the documents.

\section{DOCUMENTS OF BRITISH HISTORY}

WITH PROBLEMS AND EXERCISES

Sections I. V. are reprinted from $A$ History of England for Schools.

In one Volume. Large Cr. 8vo. Cloth. 3s. 6d.

Or in six Sections. Limp Cloth. 8d. each.

I. A.D. 78-1216. IV. A.D. 1603-1715.

II. A.D. 1216-1399. V. A.D. 1715-1815.

III. A.D. 1399-1603.

London. Teacher.- "Extremely useful for class work in history."

\section{INTRODUCTION TO WORLD HISTORY}

With 23 Illustrations and 21 Maps and Plans.

In one Volume. Large Cr. 8vo. Cloth. 2s.

Scotsman.- "It is a skilful and well-proportioned sketch of a largesubject, well devised to meet the needs of school teachers who wish a ready means of imparting the time-perspective of the events of universal history. Its narrative is simple, concise, and interesting, and well supplied with maps and illustrations."

A. \& C. BLACK, $4,5,8$ \& SOHO SQUARE, LONDON, w. 


\section{STUDIES}

IN THE

\section{TEACHING OF HISTORY}

BY

M. W. KEATINGE, M.A.

READER IN EDUCATION IN THE UNIVERSITY OF OXFORD

LONDON

ADAM AND CHARLES BLACK

I 9 I 3 
First published January y910

\section{AGENTS}

America . . The Macmillan Company

$64 \& 66$ Fifth Avenue, New York

Australasia - The Oxford University Press

205 Flinders Lane, Melbourne

Canada . . The Macmiltan Company of Canada, Ltd.

St. Martin's House, 7o Bond Street, Toronto

India . . Macmillan \& Company, Ltt.

Macmillan Building, Bombay

309 Bow Bazaar Street, Calcutta 


\section{PREFACE}

THE following pages are concerned with the teaching of boys and girls in the middle forms of secondary schools, and even for this stage deal with only a small number of the numerous problems presented by the teaching of history. They aim at bringing into strong relief a few fundamental positions, and make no claim to be an exhaustive treatment of the subject. If, therefore, certain methods and principles of proved value are not mentioned, it must not be concluded that they have been either overlooked or undervalued.

My thanks for valuable advice are due to my colleague Miss A. J. Cooper, to Mr. J. Wells, Fellow and Tutor of Wadham College, to Mr. J. B. Baker, Tutor to the NonCollegiate Students, and to Mr. E. Barker, Fellow and Tutor of St. John's College. It must not be assumed that they are necessarily in agreement with my views. I have also to acknowledge the kindness of Prof. Foster Watson, who allowed me to see the proof-sheets of his book, The Beginnings of the Teaching of Modern Subjects in England, and of Messrs. A. \&. C. Black in permitting me to use extracts from their publication, English History Illustrated from Original Sources.

$$
\text { M. W. KEATINGE. }
$$

OXFORD,

October I909. 


\section{CONTENTS}

\section{CHAPTER I}

The Problems of Method and of Value . . ${ }^{\text {Pagk }}$

\section{CHAPTER II}

Scientific Method in History and the Problems OF THE SCHOOL. . . . . . . 20

\section{CHAPTER III}

CONTEMPORARy DOCUMENTS AS A Basis OF METhod . 36

\section{CHAPTER IV}

CONTEMPORARy DOCUMENTS AS AtMosphere • $\quad 96$

\section{CHAPTER V}

Method and Moral Training . . . . . 105

CHAPTER VI 
CHAPTER VII

The Organisation of History Teaching . . I I5I

\section{CHAPTER VIII}

History and the Examination System . . . 168

\section{CHAPTER IX}

History AND POETRY . $\quad . \quad$. $\quad . \quad$. $\quad$. 189

\section{CHAPTER X}

Some Problems and Devices of Class-Room Practice 213

\section{CHAPTER XI}

The Teacher of History. . . . . . 222

INDEX $\quad . \quad+\quad \cdot \quad \cdot \quad \cdot \quad \cdot 23 \mathrm{I}$ 


\title{
STUDIES IN THE TEACHING OF HISTORY
}

\author{
CHAPTER I \\ THE PROBLEMS OF METHOD AND OF VALUE
}

THOSE who write at large on Education seldom realise that the branches of knowledge commonly taught in schools vary greatly in the ease with which they lend themselves to manipulation. Indeed, this aspect of school studies does not interest them. Modes of handling a subject seem almost superfluous if that subject is evidently a good one. To the man who feels that there is a message of some kind to deliver to the younger generation, that there are departments of knowledge whose content is matter of vital import for the understanding of human character and of human society, the delay caused by discussions upon method is apt to be most irksome. "My subject," the historian will say, "is of acknowledged value. No one can be ignorant of it without grave injury to his social or commercial or religious relations. Let us force it into the curriculum at any cost and trust to fortune and to common sense that some method of handling it will be found."

Now fortune is a dependable ally only when steps 
have been taken to succeed without her aid, and the common sense of teachers, while it has dimly felt the problem, has tended to exclude history from the school precincts rather than to establish methods for its treatment. If for generation after generation schoolmasters have virtually refused to recognise the importance of history, the reason probably is that it has appeared too vast and untrodden a domain to venture upon without long consideration, and as the turmoil of a schoolmaster's life leaves no leisure for consideration even of a scanty kind, the old subjects hold the field. And they do so largely because they lend themselves to teaching, because as instruments for making boys think and work they are difficult to spoil or to render wholly useless.

What are the elements necessary in a subject which is to lend itself to manipulation? It is easy to sketch in the qualifications. In the main they are four in number. The apparatus must be inexpensive and readily procured; it must be easy to see what is the teacher's work on the one hand and the boy's work on the other; there must be a facility for setting home work that shall be different in kind from the work done in class, and these exercises must be fairly mechanical (for too much refined judgment must not be expected from the average boy); it must be possible to attain to some generalisations, abstractions, or rules which can be applied to fresh matter. Indeed, it is upon the presence of this latter element that most of the others depend.

The older subjects fulfil these conditions well. Given a plain text of Cæsar's Gallic War, a Latin Grammar and a dictionary, the boy can be set a great variety of work. The materials are not costly, each page provides 
a number of problems to be solved and the attack upon these and the unravelling of the meaning is a genuine preparation for the lesson which is to follow. The work of the teacher in testing preparation and in aiding interpretation is easily discerned. Syntactical generalisations in abundance can be derived from instances in the text, and the application of these in retranslation passages and composition is a genuine application exercise. Again in such a subject as arithmetic the conditions are all fulfilled. Definite generalisations or rules can be reached: "Invert the divisor and multiply." These can be applied to an indefinite number of examples or problems, and the boy's part of working examples can readily be distinguished from the teacher's part of developing arithmetical processes. Finally, in both cases the boy can be given a large amount of work to do apart from the teacher, or in other words the teacher need not be teaching all the time-an important consideration for a man who has a full teaching week.

When we turn to history we find the conditions very badly fulfilled. It is difficult to devise preparation for the boy other than the learning from a text-book of the facts of the lesson that is to be given or the revising of the facts of a lesson that has been given. In school work it is not always possible to arrive at historical generalisations and apply them to fresh matter. In other words, apart from essay-writing, of which with middle-school boys it is not easy to vary the form, exercises are difficult to find. It needs all the devices of a practised schoolmaster to make the class contribute much to the development of the lesson. The limits of change appear to be the short lecture, the lecture interspersed with questions, the 
expansion of the text-book, the occasional setting of problems, the written answer of fact and the essay; while the latter exacts much time from the master who looks it over. In this subject more than in any other it seems as if the maximum of work were demanded from the teacher and the minimum from the pupil. The old relations are reversed; the teacher prepares his lessons and the pupil hears them.

Now a subject to the development of which the pupil is not himself always contributing soon ceases to excite his interest. Experience shows that the best lectures, although at first listened to with respect, engender listlessness and inattention as term advances; and yet lecturing in some modified form is the first method that suggests itself in history teaching. Thus as far as its form is concerned, history appears to be a bad school subject, and if its content were unimportant, it might well be left on one side as too exacting for practical purposes. If, however, it can be shown that the content of history is of value for educational ends it will be worth while to spend some pains upon it. If, further, it can be shown that for educational purposes no other complex of ideas is of such real importance, no trouble will be too great, if only we can succeed in getting into order this somewhat unmanageable subject.

It is not easy to make a brief statement of the advantages to be derived from the study of history, for, indeed, their number is overwhelming. Without some acquaintance with origins no man can understand the civilisation into which he is born, and not understanding it he will take no interest in its problems. His social and political vision will be dim 
and uncertain, his horizon will not extend beyond his own immediate needs. Unlike the sufferer from cataract the mentally blind can find no surgeon to cure him by a speedy operation, for his ignorance begets prejudices whose growth is proportional to the efforts to heal him. Lack of interest in human factors is a serious deficiency, and its seriousness is especially felt in the modern self-conscious democracy. The individual has not only to realise that problems exist; he is asked in addition to have definite views upon them, and the definiteness required is that which arises out of knowledge rather than that born of ignorance. The voter of the present day is asked to come to a decision upon matters of foreign and home politics. $\mathrm{He}$ is expected to have views upon social matters, and to act upon them at the polling booth; and he will criticise the report of the Poor Law Commission. He may belong to a religious community, or he may not; in either case he has his share in making legislation that decides the relation between the State and the Churches. $\mathrm{He}$ is not surprised if asked to choose between Free Trade and Protection, and is in no way deterred from doing so by his ignorance of both. He will decide that more Dreadnoughts are necessary, or fewer, as the case may be, hoping to find out at a later date what exactly a Dreadnought is and its importance to his country. $\mathrm{Hc}$ swells with pride at our position in India, and criticises the action of the Viceroy or the attitude of the Home Government from the lofty standpoint of the voter who ultimately controls both.

And yet how many of the ordinary citizens of this country, men, let us say, prospering in business or professional life, have either acquired at school or 
received the stimulus which would lead them later on to acquire for themselves the knowledge that is required for sound judgment in these matters? If the relations between this country and others is in question, how many adults have a sound understanding of the political factors in Europe and the manner in which they arose? How many could even give an account of the causes which led up to the war of 1870-7I? In home politics how many of the people who look upon the Irish as a race of irreconcilables perpetually occupied in making irrational demands have the slightest acquaintance with Irish history or with the genesis of the Irish character and conditions? How many have even a fair acquaintance with the history of the working classes between the reign of Edward I. and the present day, or of the separation of the Anglican Church from Rome and the growth of Nonconformity, or of the various attempts made to aid trade by restricting it from the fourteenth century to the present day, or of the development of the navy from Henry VIII. onwards? How many could give even a slight sketch of the history of India, of the diverse races to be found there and of the peculiar political problems that arise out of this diversity?

A very slight acquaintance with men in different stations of life shows that in spite of the increased attention paid to history in schools during the last decade (for it is apparently only those who write to the daily papers on matters of education who can venture to neglect the changes that have taken place in schools since their own school-days), a lamentable ignorance is everywhere to be found. Men who would be ashamed of mistakes in classical scholarship, or of mathematical inaccuracy, will readily confess their ignorance as 
regards the history of an institution as well as their indifference to it. In many societies to be ill-read in the cricket or football news may be a source of real discomfiture, to be ill-informed as to the history of a movement which is of vital importance to the community need not cause anxiety to any one.

It is precisely in respect of the type of historical information above alluded to-information of an almost crudely utilitarian kind-that we might have expected to find a widely-diffused sense of its value. It is on this aspect of history-values that it is wise to lay stress when appealing to the common sense of the average citizen, and if we receive an unsympathetic hearing it is perhaps useless to display the other values of our subject. Yet it is as an introduction to the world of human nature that history is chiefly to be prized. If stress is laid on the biographical side, history is a panorama of character in action in every conceivable situation, it widens indefinitely the circle of our acquaintances, it provides abundant material for the analysis of motive, it gives opportunity for cultivating restraint in the admiration of pleasant personalities and charity in the judgment of unpleasant ones. By bringing the learner into contact with civilisations and societies unlike his own it lessens race and class prejudice. In its chronological aspect it introduces us to the gradual development of civilisation in time. In all these and in other directions the value of history is difficult to overrate, and impossible to express in a few words. With no subject does the teacher stand in closer connection, since it is he who should pass on to the younger generation the sacred flame from previous ages. The State, when it passes on the material possessions of one generation to the next, 
claims as its due a substantial death-duty, the price of the security that it affords to this transmission of personal rights. Similarly the teacher has on the State no stronger claim than this, that he hands on to the young the possession of their fathers' hard-won experience, and by the integrity of his presentation ensures the continuity of historical interest.

Writers on education since the Renaissance (quoting Cicero in support of their views) have held opinions which agree closely with those expressed above. In his Essay, De Ingenuis Moribus, written in 1392 for the son of Francesco Carrara, the lord of Padua, Vergerius says : "Among liberal studies I accord the first place to history, on grounds both of its attractiveness and its utility. History gives us the concrete examples of the precepts inculcated by philosophy." 1 Lionardo D'Arezzo expresses himself similarly in 1405: "First among such studies I place history, a subject which must not, on any account, be neglected by one who aspires to true cultivation. For it is our duty to understand the origins of our history and its development." ${ }^{2}$ In 1450 Æneas Sylvius (Pope Pius II.), after recommending the study of Livy, Sallust, Quintus Curtius, Valerius Maximus, and Arrian (in a translation), together with portions of the Old and New Testament, e.g. parts of Genesis, Kings, Maccabees, Judith, Esdras, and Esther ; and of the Gospels and the Acts of the Apostles (advice that is rather unexpected as coming from a Pope), adds: "It is most important to be thoroughly versed in the works of the chief historians, and from their study learn practical wisdom in affairs. But I would add here a most serious

1 Woodward, Vittorino Da Feltre, and other Humanist Educators, 1907, p. 106.

2 Ibid. p. 12. 
caution. Beware of wasting time over such a subject as the history of Bohemia or the history of Hungary. For such would be but the productions of mere ignorant chroniclers, a farrago of nonsense and lies, destitute of attraction in form or style or in grave reflections." 1

It is evident that the history which these writers had in mind was rather that of their ancestors, the Romans, than the history of mediæval Europe, and it must not be forgotten that to the schoolboy of the Renaissance the Latin lesson, with Livy for a reading-book, was a lesson in history quite as much as in linguistics. While, no doubt, it was as difficult for the Italian as for the English schoolboy to become a finished scholar, it must have been far easier for him to read Livy quickly and thus to master its historical content intelligently than for the German boys on the other side of the Alps who brought to the task no stock of similar works in the vernacular, and therefore had to spell out the content laboriously with the aid of a dictionary. For this reason it is unlikely that in the post-Renaissance schools in Germany and England, where the classical authors were read more for their style than for their matter, the historical content was realised so fully as by the Italian boys.

None the less when schoolmasters of any eminence expressed their views on education they frequently demanded history, and plenty of it, in the curriculum. "An acquaintance with history," said Comenius, " is the most important element in a man's education, and is, as it were, the eye of his whole life. This subject, therefore, should be taught in each of the six classes (of the grammar school), that our pupils may be ignorant of no

1 Woodward, Vittorino Da Feltre, and other IIumanist Educators, 1907, p. 152. 
event which has happened from ancient times to the present day. Our idea is that each class should have its own handbook dealing with some special branch of history. Class I. An Epitome of Scripture History. Class II. Natural History. Class III. The History of Arts and Inventions. Class IV. The History of Morals. Class V. The History of Customs treating of the Habits of Different Nations. Class VI. The General History of the World and of the Principal Nations, but especially of the boys' native land, dealing with the whole subject tersely and comprehensively." I Locke also, who, though probably not representative of scholastic views in the seventeenth century, has strongly influenced subsequent opinion, lays stress on chronology, "that the pupil may have in his mind a view of the whole current of time and the several considerable epochs that are made use of in history. Without this, history, which is the great mistress of prudence and civil knowledge, and ought to be the proper study of a gentleman or a man of business in the world, will be very ill retained." 2

In education the gulf between theories and practice is great. Sturm laid no stress on history in his Strasburg school, neither did the Jesuits in their establishments, nor Calvin in his grammar school at Geneva, nor the schools in Scotland founded on his model by John Knox. In English schools a manual of English History was actually ordered by the Privy Council in 1582 to be read in schools, ${ }^{3}$ but for the sake of the boys of the period it may be hoped that the order was disobeyed.

1 The Great Didactic, chap. xxx.

2 Thoughts on Education, sec. 182.

3 Anglorum Proelia, ab A.D. 1327 usque ad ann. 1558. Christophero Oclando authore, London, 1580. Ocland was master of St. Olave's School, Southwark. 
Here is a taste of it dealing with that old friend of the text-books, the Wars of the Roses:-

nobilitata inter plures haec sunt loca caede, Albani fanum, Blorum, Borealis et Hampton, Banbrecum campis, Barnettum collibus haerens, experrectorum (Wakefieldia) pagus, fanumque secundo Albani, propior Scoticis confinibus Exam. contiguoque istis habitantes rure coloni, moerentes hodie, quoties proscindit arator arva propinqua locis dentale revellere terra semisepulta virum sulcis cerealibus ossa.

In 1650 Alexander Ross brought out an abridgment of Raleigh's History of the World under the title The Marrow of History, and as he was a schoolmaster the book may have been read by his pupils, but of this there is no evidence. From this time onwards there is a continuous stream of text-books, but absolutely no indication that the subject was treated in schools as of any real importance; indeed such text-books seem to have been used as material for Latin prose composition quite as much as for their historical value. ${ }^{1}$

It was not wholly through inadvertence that history was thus degraded to be a menial accessory of linguistics. The object of history was considered to be the illustration of abstract moral maxims, and as Aristotle had considered "moral philosophy" unsuited for the young, history was similarly thought to be beyond the grasp of schoolboys. $^{2}$ In his inaugural lecture Degory Wheare, the

I New Thoughts concerning Education, by M. Rollin. Eng. Trans., 1735, p. 72, note by translator upon a History of England recently published for schools "which may be of great benefit to the youth who may make their Latin exercises by it."

2 The Method and Order of Reading both Civil and Ecclesiastical Histories, by Degory Wheare, Cambden Reader of History 
first Camden Reader of History at Oxford, discusses the matter, and wonders that Voss, "who deserves to be numbered among the princes of learning in this age, should in his elegant book, De Arte Historica, maintain that this sort of study is fit for young men." 1

Of theoretical writers on Education during the last century, only two have objected to history as a school subject. Herbert Spencer, writing before r 860 , found that the history of the text-book of his day was educationally valueless, and he was probably right; while Bain considered the subject too easy and too full of contentious matter for inclusion in the school curriculum. ${ }^{2}$

in Oxford, 1710, p. 1 5. "History is the register and explication of particular affairs, undertaken to the end that the memory of them may be preserved and so universals may be the more evidently confirmed, by which we may be instructed how to live well and happily."

1 The Method and Order of Reading both Civil and Ecclesiastical Histories, p. 299. Wheare gives succinctly the arguments used on each side by Keckermann and Voss. According to Keckermann, histories contain nothing but examples of precepts, and method should precede, just as it is absurd for a man to desire to know and observe the examples of grammar, logic, or rhetoric, before he has learned the rules of those sciences; thus one cannot read history, which is nothing but examples of morality and politics, till one has learned the rules and methods of morality and policy. On the other side Voss points out that languages may be learned without grammar rules, and that Keckermann confounds the naked and simple history of things with the historical perfection which inquires curiously into the circumstances and causes of events.

$2 \mathrm{H}$. Spencer, Education, pp. 30, 31.-" The information commonly given under this head is almost valueless for purposes of guidance. Scarcely any of the facts set down in our school histories, and very few of those contained in the more elaborate works written for adults, illustrate the right principles of political action." A. Bain, Education as a Science, 1878.- "The fact that history presents no difficulty to minds of ordinary education and experience, and is, moreover, an interesting form of literature, is a sufficient reason for not spending much time upon it in the 
As will be seen, both modern opinion and modern practice in schools tend greatly to undervalue the importance of history; but before proceeding to consider this, it will be well to learn the views of the only historians during the last two hundred years who have combined with their expert knowledge a great interest in, or a thorough acquaintance with, the problems of education and of school-life-Rollin the historian, and Dr. Arnold of Rugby.

Rollin, in his time an educational authority of undoubted weight, speaks with certainty and conviction : "I look upon history as the first matter to be given to children, equally serviceable to entertain and instruct them, to form their hearts and understandings, and to enrich their memories with abundance of facts as agreeable as useful. It may likewise be of great service, by means of the pleasure inseparable from it, towards exciting the curiosity of that age which is ever desirous of being informed and inspiring a taste for study. Thus in point of education it is a fundamental principle, and constantly observed at all times, that the study of history should precede all the rest and prepare the way for them." 1

Dr. Arnold's views, though only one hundred years curriculum of school or college. When there is any doubt we may settle the matter by leaving it out. A very searching inquiry into modern events brings out such a variety of opinions in practical politics and still more in religion as to make an obstacle to the introduction of the subject into higher schools."

1 The Method of Teaching and Studying the Belles-Lettres, by M. Rollin, late Principal of the University of Paris, translated in 4 vols., I 734, p. 6. Further on Rollin lays stress on four points. We should (I) endeavour to find out the causes of events; (2) study the character of the people and great men mentioned in history; (3) observe in history what relates to manners and the conduct of life ; (4) carefully take knowledge of everything that bears any relation to religion. 
later, show a great advance in the stress laid upon the formal element in history, but in the main he agrees with Rollin. In one of the few specific essays on education that he wrote he begins by dealing with a possible misunderstanding." "In the statement of the business of Rugby school, which has been given above, one part of it will be found to consist of works of modern history. An undue importance is attached by some persons to this circumstance, and those who would care little to have their sons familiar with the history of the Peloponnesian War are delighted that they should study the campaigns of Frederick the Great or of Napoleon. Information about modern events is more useful, they think, than that which relates to antiquity; and such information they wish to be given to their children." After cavilling at the suggestion that it is desirable to fill boys with useful information, and giving some brief hints as to a method of teaching history in the elementary stage, he proceeds: "Supposing a boy to possess that outline of general history which his prints and his abridgments will have given him, with his associations, so far as they go, strong and lively, and his desire of increased knowledge keen, the next thing to be done is to set him to read some first-rate historian whose mind was formed in, and bears the stamp of, some period of advanced civilisation analogous to that in which we live. In other words, he should read Thucydides or Tacitus or any writer equal to them, if such can be found belonging to the third period of full civilisation, that of modern Europe since the Middle Ages. The particular subject of the history is of little moment so long as it can be

1 An article contributed to the Quarterly Journal of Education in 1834 . 
taken neither from the barbarian nor from the romantic, but from the philosophical or civilised stage of human society; and so long as the writer be a man of commanding mind, who has fully imbibed the influences of his age, yet without bearing its exclusive impress. And the study of such a work under an intelligent teacher becomes indeed the key of knowledge and of wisdom : first it affords an example of good historical evidence, and hence the pupil may be taught to notice from time to time the various criteria of a credible narrative, and by the rule of contraries to observe what are the indications of a testimony questionable, suspicious or worthless. Undue scepticism may be repressed by showing how generally truth has been attained when it has been honestly and judiciously sought; while credulity may be checked by pointing out, on the other hand, how manifold are the errors into which those are betrayed whose intellect or whose principles have been found wanting. Now, too, the time is come when the pupil may be introduced to that high philosophy which unfolds 'the causes of things.' Let him be taught to analyse the subject thus presented to him ; to trace back institutions, civil and religious, to their origin; to explore the elements of the national character, as now exhibited in maturity, in the vicissitudes of the nation's fortune, and the moral and physical qualities of his race; to observe how the morals and minds of the people have been subject to a succession of influences, some accidental, some regular; to see and remember what critical seasons of improvement have been neglected, what besetting evils have been wantonly aggravated, by wickedness or folly. In short, the pupil may be furnished as it were with certain formulæ, which shall enable him to read all 
history beneficially; which shall teach him what to look for in it, how to judge of it, and how to apply it. Education will thus fulfil its great business, as far as regards the intellect, to inspire it with a desire of knowledge, and to furnish it with power to obtain and to profit by what it seeks for."

It may be noted that when he talks of history, Rollin has in mind ancient history, while Dr. Arnold, though he lays great stress on ancient history, does not exclude modern history, and was in fact one of the first, if not the first, headmaster of repute to give modern history a definite position in the time-table. Now no one who has had a classical education is likely to undervalue the knowledge of Greek and of Roman civilisation that he derived from it, for this knowledge has been acquired in a fashion that ensures its wearing well. It has soaked gradually into the mind while the linguistics have been mastered sentence by sentence and construction by construction. It has generally been concerned with a few limited and important periods. It has been gathered from the original documents, from works written with the intimacy but also with the limitations of those who were near the events, and together with the sequence of the narrative there has been acquired a fair intimacy with a few of the principal actors. Not only has a necessary basis been laid for the further understanding of history, but the method of laying it has been the soundest one possible. But although this is true, its truth may be an obstacle to a discussion upon the teaching of history in general, unless certain other facts are well borne in mind.

In the first place, it may be doubted if as much history is at present. acquired through the classics as was the 
case a few generations ago, when less stress was laid upon critical questions and upon composition for scholarship purposes. In the second place, fewer boys read the classics, and even these in most schools devote to them a much smaller number of hours than formerly. In the third place, an increasing number of boys read no classics at all, or at most acquire the rudiments of Latin. In the face of these facts to reiterate the statement that history can profitably be learned only through the classics is to leave the subject to the crammers and the textbooks. Dr. Arnold has been quoted at length because he demands a factual knowledge of modern history in addition to the formal training to be derived from the study of the ancient historians, and because he writes with an enthusiasm born of his study both of history and of boys. Nothing is more striking than the difference of the note sounded by modern writers. In the preface to his excellent Introductory History of England, Mr. C. R. L. Fletcher says roundly that "for English History as part of a school curriculum or as a means of education I have no regard at all. The substitution of modern history and other modern subjects in our great schools for Greek and Latin I regard as nothing short of an irretrievable calamity." 1 Mr. A. Hassall follows in a similar strain: "It is doubtful if many schoolmasters have yet discovered the best methods of training boys in history. In far too many instances Greek and Latin History is displaced for mediæval and modern History." 2

1 It is open to question whether the mischievousness of this statement coming from a writer of merit is aggravated or palliated by the excellence of the history which follows.

2 The Public Schools from Within, 1906, article on History. Apparently no schoolmaster could be found "from within" to write the chapter. 
An Eton master, responsible for the teaching of history, is rescrved in the statement of his views: "The claims of History are still matters of dispute." 1 Apparently he has good reason for saying so. "Our public schools teach little or nothing about the Empire. English History and Literature are barely tolerated." 2 It is not many years since the headmaster of a great school stated at the Headmasters' Conference that history could be nothing but a cram subject. ${ }^{3}$ A Clifton master expresses the same sentiment: "Exceptional boys apart, history should be a purely subordinate study, as it tends to become vague, desultory, or didactic." 4

When made in connexion with the classical side of a great school the plea that the classical history does what is necessary, though misleading, contains a half truth; it is when such a half truth is used to justify the neglect of an important subject on modern sides that its mischievous nature is apparent. It is noteworthy that in the accounts of the Modern Sides at Public Schools recently published by the Board of Education there is no indication that the subject is looked upon as one of first importance, or that any attempt has been made to fashion it into a real ergastulum. ${ }^{5}$

1 The Teaching of History, 1901, p. 91, chapter on "The Teaching of History in Schools," by Mr. C. H. K. Marten.

2 Rev. T. L. Papillon, in The Public Schools from Within, p. 284 .

3 A distinguished teacher of history at Oxford has assured the writer (I) that boys should learn no history at school, but should reserve this study for the University; (2) that if those who do not go to a University must learn some history, this should be limited to an outline of facts and dates.

$4 \mathrm{Mr}$. A. B. Mayor, in Moral Instruction and Training in Schools, edited by M. E. Sadler, vol. i. p. 142.

5 Board of Education. Educational Pamphlets, Nos. 3, 7, 8, 
The truth is that the burning conviction which underlies the expression of Arnold's views, the feeling that a training in history, and more particularly in certain elements of historical method, is of such vital importance that with whatever expenditure of trouble, or at whatever neglect of other subjects, the subject must be given a prominent place and worked so that it commands respect, is nowhere to be found. Owing to the pressure of external examinations a modicum of historical fact has to be got up, but in most schools history is still casually classed under what are called "the English subjects," and the methods adopted in teaching it are probably as casual as the classification.

When a subject with such strong claims is habitually discredited by men engaged in serious educational practice the cause doubtless is, in certain cases, ignorance and perversity; but on the whole it is more likely to be the welljustified feeling that a subject in which the work has to be done for the boy by the teacher, ${ }^{1}$ which in the long run resolves itself into either listening to interesting matter or lcarning by heart, which is, in short, a soft option, is unsuited to be a main study for boys of a certain age.

It is, however, by no means certain that history is of this nature or need be taught in this way, and it is clear that if the subject is of first-rate importance, the problem of method deserves serious attention. It is in the belief that for purposes of culture no other subject can approach history, that the following pages have been written.

ro, dealing with the Modern Sides at Harrow, Rugby, Eton, and Dulwich.

I Mr. C. H. K. Marten, op. cit.: "It is the teacher-before a boy can read much for himself-who must generalise from and analyse facts; who must give his judgment on men and events, who must explain causes and estimate effects." 


\section{CHAPTER II}

SCIENTIFIC METHOD IN HISTORY AND THE PROBLEMS OF THE SCHOOL

As soon as the nursery period is over, three stages of history teaching may be distinguished. The first covers approximately the years between seven and twelve, the second those between twelve and sixteen, and the third the last three years of school life. Demarcation of periods by age can give only a partial indication of the degree of mental development implied, as boys vary greatly. On the whole, however, if we take it that exceptional boys may be some years ahead of or short of the average, these three stages correspond to the facts of school life, and may be termed the preparatory, the secondary, and the upper secondary. It is impossible to read the various essays that of late years have appeared on the teaching of history without noticing that writers who deal with the first stage have no misgiving as to the value of their subject. "Almost all who have taught history to boys and girls," says Mr. A. M. Curteis, "agree in estimating its relative value very highly." And again, "the masters of preparatory schools as a body are convinced that, apart from the actual knowledge gained, the process of gaining it helps to strengthen memory, that it is one of the most effectual means of 
developing intelligence and training judgment, and that it awakens imagination." 1 So also the late Professor Withers, writing with particular reference to elementary schools: "A man who is ignorant of Algebra cannot be called 'uneducated' in the same sense as a man who is ignorant of History, nor is his ignorance likely to be so injurious to himself and to others." 2 This unanimity of opinion, of which it would be easy to give further instances, is not difficult to account for. The more obvious methods of teaching history, those upon which a teacher interested in his subject but with no school tradition to draw upon is most likely to chance, are just those that prove to be most suitable for children of this age, while in addition it is tacitly taken for granted that the subject is a very subsidiary one, to which one or at most two hours a week are given. For the teaching of history during this preparatory stage the method is largely one of presentation. The instruments are a textbook or a reading-book, pictures in the books used and on the walls of the class-room, and collections of suitable ballads, while stress is laid upon the biographies of men of action, and these are made the concentration points of the narrative. It is not for a moment implied that boys of this age are to be purely receptive, that they should only read the text-book, look at pictures, and listen to well-told descriptions of persons and events. The clever teacher will, with the older boys at any rate, encourage some note-taking, will ask questions that stimulate thought, and will set written work that demands

1 Special Reports on Educational Subjects, vol. vi., Preparatory Schools for Boys, art. on "The Teaching of History in Preparatory Schools," by A. M. Curteis.

2 Memorandum on the Teaching of History, by Professor H. L. Withers, M.A., I90I. 
it ; and for boys of this age it may even be sufficient, in a lesson that comes once or at most twice a week, if the imagination is excited and interest is aroused. But probably towards the end of this stage, certainly as soon as the next is reached, and with a force that increases with each successive year, it becomes apparent that something more is needed. In comparison with the linguistic or the mathematical lessons which daily are making further demands upon the thinking powers, the history lesson seems to the boys to be a breathing-space, interesting enough, no doubt, if the teacher is good, but not one in which a scrious effort, comparable, say, to that required in solving algebraical problems, has to be made. When once a boy feels this, his respect for a subject vanishes, and he labels it as a soft option.

Now for soft options, for subjects that are not taught in such a manner that the boys feel their seriousness, there is in the curriculum no room at all. It is already overcrowded, and often, as result, ten subjects are taught badly where four or five used to be taught well. If it is maintained that a few soft hours are needed to avoid over-pressure, the answer is that in that case the boys would be better off out of doors, or in the workshop, or at a choral practice. There ought to be no middle way between teaching a subject as a pure convention and equipping it with a real method. If the first course is decided upon, if it appears good to lay stress upon subjects other than history but to teach it because it would make a bad impression upon parents if it were omitted from the time-table, or because it is desirable that a boy should be cognizant of a few of the leading names and dates in English history, let it be taught from this standpoint. Let twenty to forty minutes a week be 
given to it, and let the brute facts be administered from a text-book by a strong disciplinarian. This will waste little time, and the professed aim will be attained. In this matter there must be no shirking of the issues. The history hour can provide either a modicum of conventional knowledge, of which much is almost valueless as mental content, and much will be forgotten within a few years of leaving school, or it may supply a real training in observation, judgment, and expression. As with every other subject, we must definitely select our aim, and having done so must take steps to ensure its attainment.

The sound method of teaching any subject in schools must always stand in close relations with the scientific development of that subject, and in particular with the formal treatment of that scientific development by the logician. It is noticeable that in schools the handling of many subjects remains centuries in arrear of their scientific development. Napier, for example, discovered logarithms in 1612. It was not till the end of the nineteenth century that they were placed as an instrument in the hands of middle-school boys. ${ }^{1}$ Only thirty years ago the teaching of science in many schools (at this date school science meant chemistry) was based solely upon the text-book, and it was possible for a candidate to pass an examination like the University of London Matriculation without having seen or handled a piece of chemical apparatus. Since that date there has been development in several directions. Increased attention has been given to the methods of inductive science.

1 They were introduced at the Royal Naval College, Osborne, in 1904 , at Winchester a few years earlier, and doubtless in other schools at about the same time. 
Indeed, since the formal inductive methods were stated by J. S. Mill they have been repeated, modified, and criticised in every serious work on logic, and men of science themselves, though probably quite careless of the attention paid to their methods by logicians, read and are affected by works like Professor Karl Pearson's Grammar of Science. As a consequence partly of this increased consciousness of method, and partly of the teaching instinct on the part of teachers who felt that if science had to be introduced into schools, means must be devised for giving their pupils plenty of active work, ${ }^{1}$ laboratories have been introduced into schools, and in these opportunity is given for observation and investigation. In addition, by some schoolmasters at any rate, the pupils are compelled to consider the logical processes through which they have gone and to realise how much of the result attained has been given to them, how much they have proved for themselves, and the degree of validity of that proof. It is also suggested, though perhaps not yet to any extent realised in practice, that older pupils should be introduced to some consideration of the nature of the ultimate hypotheses in chemistry, physics, and biology. ${ }^{2}$

Turning to the scientific treatment of history we find a similar development in the attention paid to method, although this does not yet seem to have affected school-

1 And, it may be added, in spite of the injudicious and sometimes ill-expressed advocacy of certain Professors of natural science.

2 A most interesting sketch of a method by which, starting from the experiments of the school laboratory, an insight may be given into these ultimate facts of science, is to be found in Philosophische Propädeutik auf naturwissenschaftlicher Grundlage für höhere Lehranstalten, von August Schulte-Tigges, I 900. 
teaching. From the sixteenth century onward there have appeared at intervals works treating of the logical processes through which the historian goes, and of recent years this consciousness of method has found expression in several important works. ${ }^{1}$ A brief account of the function, the scope, and the materials of the historian, as stated by Bernheim and others, will facilitate the business of this essay.

The conception of the function of history has gone through three stages. In the first it is narrative, and conditioned by æsthetic interest and imagination. In the second it is instructive, embodies more reflection, and may be actuated by patriotism or by moral aims. In the third it seeks to know how each individual event came into being and developed in the complex of conditions, and busies itself with notions of causation. ${ }^{2}$ The growth of this conception, it may be observed, stands in close relation with the methods which can successively be adopted in the various school stages. In the preparatory stage the presentation might be xsthetic and interesting, in the secondary stage moral aims and reflections might be introduced, while the tracisg of cause and effect might be reserved for the third or upper secondary stage. It is, however, not permissible to base method upon such a crude notion of psychological development. This was Rousseau's mistake; since his time it has been recognised that mental growth is gradual, and cannot be split off into sections, each displaying a marked difference

1 Chief amongst these is Bernheim's Lehrbuch der historischen Methode, 6th edition, 1908. An account of the works in which historical method has been treated since the sixteenth century will be found on p. 217.

2 Bernheim, op. cit. p. 22. 
from those which immediately precede and follow. The preparatory stage, it is true, stands in marked contrast to the upper secondary as regards mental powers, but it develops gradually into it through what we have called the secondary stage, and it is precisely at this point that our difficulty is greatest. For here the various mental qualities and powers are all present in embryo, sometimes to a considerable degree of development, and it is not easy in general terms to say how much it is safe to take for granted; but of this later.

Accompanying this increasing clearness in the conception of the stages of history there has arisen a tendency to widen the scope of the subject matter that falls within its province. We have, in fact, confronting one another two great groups or complexes of sciences; on the one side natural science, dealing with the facts of physical nature, their investigation and manipulation, and on the other a group consisting of history, anthropology, sociology, and psychology, dealing similarly with the facts of human nature. As many of these subjects are only just coming into existence, it is not easy to delimit their spheres. For instance, the exact relation in which history stands to sociology is to some extent a question of terms, and is complicated by the tradition of the positive philosophy that lingers round the term sociology, since this was first used by Comte to denote the science of human nature regarded as conditioned by purely physical causes. The term is, however, now used without this implication to denote a group of human phenomena wider than that treated of by the conventional history of the last generation, which, tc a large extent, excluded economic and social questions. Its nature is made clear by a syllabus of sociology 
suitable for secondary education suggested by M. A. Fouillée. ${ }^{1}$

I. Importance of sociology. The nature of society. Is it a simple collection of individuals? Is it an organism? Subordination of biological to psychological laws in sociology. The part played by sympathy, by imitation, by invention, by will, and by voluntary co-operation.

2. Conditions of equilibrium and conditions of progress tor societies and in particular for nations. The individual, the family, and the State. Nations and the psychology of peoples. The French nation.

3. Economic sociology. Production, distribution, and consumption of commodities.

4. Property from the sociological standpoint. Examination of socialist systems. Materialistic and idealistic socialism.

5. Political sociology. The principles on which democracy depends. The true meaning and limits of national sovereignty. Advantages and dangers of democracy.

6. Moral, juridical, and criminal sociology. Alcoholism. Depopulation. The growth of criminality ịn France. Juvenile criminality.

7. The republican constitution in France. The rights which it confers and the duties which it demands.

M. Fouillee adds : "In a word, under this title of sociology must be grouped a number of questions which to-day are treated without scientific method and in too dogmatic a manner."

Instead of "sociology" the term "social science" is sometimes used to indicate this complex. ${ }^{2}$ Whatever 1899.

1 A. Fouillée, Rerue internationale de sociologie, October

2 "Le mot sociologie avait été inventé par les philosophes, il correspondait aे une tentative pour grouper des branches de science restées isolées sous une conception philosophique d'ensemble. Il paraît avoir eu le même sort que cette conception: après une période de vogue, il semble menacé de sortir de la langue. Le mot sciences sociales est. entré dans l'usage pour indiquer à peu près le même ensemble d'études." 
the term employed, it is evident that there is here a complex of objects of scientific study which in part roughly corresponds to and in part arises out of the subject taught in schools under the traditional name of history. ${ }^{1}$

For this science of human life and development the doctrine of historical method now proceeds to enumerate and to classify the data. These fall under the two headings of data left unconsciously and data left consciously. The first comprises monuments, language, institutions, bodily remains; the second includes historical pictures, plans, sculptures, sagas, proverbs, historical songs, inscriptions, genealogies, calendars, annals, chronicles, biographies, memoirs, letters, state documents. $^{2}$ This catalogue of data is not without importance, as the difference in method between the two groups of nature studies and of human-nature studies depends upon the differences between their respective subject matters. In natural science the fact to be studied is before the observer, and can be repeated at will; in social science the object of study in many cases is in the first instance a document from which the historic fact has to be reconstructed. Bearing this in mind, it is now possible roughly to contrast the methods of the two sciences. In natural science we have to explain some fact, let this be rust or the rising of mercury in the barometer; we do so :-

Ch. Seignobos, La Methode historique appliquée aux sciences sociales, I 901, p. 7.

1 Bernheim is of opinion that sociology differs from history in its abstract manner of dealing with its subject matter. "Sociology ignores the individual, neglects the psychical motives and creative activity, while for history these are important factors to be discovered and known."

2 Bernheim, op. cit. p. 250. 
I. By considering a number of hypothetical causes which we are led to imagine by our knowledge both general and particular of the manner in which elements affect one another.

2. By then trying the supposed causes until finally we see, say, rust produced. If we are then certain that only the conditions which we have arranged are in operation, we have worked back to the cause.

3. The explanation is, however, not complete. It is not correct to say that we see the cause in operation. We see the cause, but the operation is an unseen one, which we provisionally describe and make concrete to the imagination by hypotheses as to the existence of atoms and molecules, and their quantitative combinations under certain laws.

In history, on the other hand, we (I) observe some human product ; it may be a monument, an inscription, or a document: in most cases the latter. (2) We reason back from the document to the causes that produced it, i.e. to the historical fact. This we do by applying a number of methodical principles. (3) Having constructed the fact we then explain it by referring it to human motive. (4) We can then, if we wish, attempt to trace the operation of this fact in the complex of other facts that we discover in the same way. Between the two groups, therefore, the following differences of method are outstanding :-

I. In history, as opposed to natural science, the fact which is at hand for observation is not the historical fact, but merely a description of it, and in many, if not in most cases, a very unreliable one. The transition from the document to the fact is difficult, occupies a great part of the historian's time, and dictates to him 
the nature of his method. In history there is thus an additional, and frequently a very uncertain step, which is not to be found to the same extent in natural science. ${ }^{1}$

2. In natural science experimentation is possible, and is in fact the basis of discovery. In history, as in all social science, experimentation is impossible. We cannot arrange the supposed causes artificially to sec if they produce the given effect.

3. Thus in history, where the first stage of reasoning is always regressive, we can only argue back to a number of hypothetical causes and discover indirectly which is the most probable. This element of probability is to be found in two stages: $(a)$ in the transition from the document to the fact; $(b)$ in that from the fact to the human cause; e.g. the shaky handwriting of a signature may indicate (I) that the writer was on his death-bed, or (2) that he was intoxicated, or (3) that he wrote it in an express train. We can only surmise with a greater or a less degree of probability from the general nature of the case, and from our knowledge of the writer and his conditions which of these causes is likely to be the right one.

It is thus to the criticism and analysis of documents that a great part of historical method devotes itself. This criticism may be of two kinds, to which the names of (I) external, (2) internal criticism are given. External criticism has as its object critical exegesis and the establishment of the correct text of a document; it asks, in other words, if the data are admissible. Internal

1 "Toute connaissance historique étant indirecte, l'histoire est essentiellement une science de raisonnement."-Seignobos, La Méthode historique appliquée aux sciences sociales. p. 5. 
criticism is concerned with the relation between the data and the facts. It has to determine "(I) what the writer really believed, for he may not have been sincere; (2) what he really knew, for he may have been mistaken." 1 Two types of criteria are thus needed: (a) criteria of sincerity; $(b)$ criteria of accuracy.

Criteria of sincerity lead us to consider the following positions :-

I. The writer sought to gain some practical advantage for himself or the group to which he belonged.

2. He was placed in a situation which compelled him to violate truth, e.g. he had to draw up a document in conformity with custom.

3. From sympathy with or antipathy for a group of men he was led to distort facts so as not to represent his friends in an unfavourable light.

4. He was induced by private or collective vanity to violate truth by exalting himself or his group.

5. The author desired to please the public or at least to avoid shocking it. $\mathrm{He}$ has expressed sentiments in harmony with popular ideas.

6. He tried to please the public by literary devices. In other words, his facts have suffered æsthetic, rhetorical, or dramatic distortion.

Criteria of accuracy draw our attention to the following possibilities :-

I. The author was in a situation to observe the fact and thought he had done so, but was prevented by, say, prejudice from doing so.

2. The author may have been badly situated for observing. He may not have been able to see and

1 Langlois and Seignobos, Introduction to the Study of History, Eng. Trans., p. 165. 
hear well. He may not have written down what he saw until some time after the occurrence.

3. He states facts which he did not take the trouble to observe, although he might have done so.

4. The fact stated is one that could not be learned by observation alone. Inference and judgment have to be allowed for. ${ }^{1}$

From this brief review it is evident that as a result of modern historical tendencies the subject matter of history is conceived of as being wider than formerly, and that for operations upon it a large number of methods and principles have been suggested. Further, it is recognised that the ultimate facts which have to be reconstituted are human motives as the causes of social phenomena; while among other topics that have received attention, and which stand in close connexion with the schoolmaster's work, is that of the relative importance in determining any event of the individual and of the social complex to which he belongs. ${ }^{2}$

There are, then, two distinct fields of knowledge, mutually opposed and yet with many bonds of connexion; that of natural science and that of human science. The schoolboy can be turned into either of them with equal ease, and in both he can be given material to observe and to manipulate, opportunities for drawing inferences, for exercising his power of working with accuracy, and for testing his strength in the attack upon difficult problems. In both it is possible to devise plenty of independent work for the pupil, in both this work can be regulated and graded until it exactly suits

1 Langlois and Seignobos, op. cit. p. 172.

2 Cf. K. Lamprecht, What is History? Eng. Trans., 1905, chap. i. 
his capacity, in both the interest of the pupil can be excited.

Thus in theory the two sides, as far as formal operations are concerned, seem to be of equal value. In practice, experience shows that this equality is not recognised. Most schools of any importance have a science laboratory, upon which a considerable sum of money is spent yearly; for the history lesson few schools supply any apparatus but a text-book and a blackboard. Natural science, as a branch of knowledge equipped with methods and apparatus, has had the start of social science. Moreover, it appeals to the crude utilitarian instinct and, in spite of the efforts of head-masters who know their business, the pressure of pseudo-utilitarianism is one which it is difficult to resist. Nor are teachers of science behindhand in finding arguments in favour of their subject. A favourite theme is the formal training to be derived from it, and we are told that science trains to observation and to inference as does no other subject. Now the argument from formal training is a weak and crumbling support. It is notorious that men who observe well in one field, and who draw sound inferences from their observations, may be unobservant and unsound of judgment in another. The stockbroker has exercised his powers of observation and of inference on the Stock Exchange; they fail him in the chemical laboratory or when literary judgment is required. The clergyman grown grey in his parish has observed much, and has drawn many a shrewd conclusion as to his parishioners' characters. His formal training would serve him but little if he attempted to apply it to the function of a bookmaker or of a commercial 
traveller. The results of formal training are directly transferable in so far as there are common elements in the subject-matters concerned. The formal training left by classical study stands me in good stead when I am attacking a modern language because the fields of action are not wholly dissimilar. But the formal training given in the laboratory cannot be depended upon for use in a sphere so different as that of human relations, and, therefore, if the two spheres are of equal importance, the attention paid to a formal training in science is no excuse for neglecting to give a similar training on the side of humanity.

This is not the place to assess the relative worth for the community as a whole of the sciences and of the humanities. To do so would necessitate an elaborate exposition of values which is beyond the scope of this essay, and for society the importance of science is unquestioned. It is a different matter when we turn to the individual. We live in an age of specialisation, a fact which Mr. Herbert Spencer in his work on Education seems to forget. It is desirable that all schoolboys should be introduced to the world of science, and to the elements of scientific method, because of their relative importance in the world which they are shortly about to enter. But once his school-days are over, not one boy in a hundred will ever again be brought into contact with chemical processes, or be compelled to make any physical calculations. The ordinary adult pays experts to perform these operations for him, and as a rule is too sensible to run the risk of doing them badly. Almost the only occasion on which the citizen ever observes the operations of nature, and draws inferences from them, is when he looks at the heavens and decides whether or 
not to take out his umbrella. Happy is the man who has learned not to do so, but to consult the weather forecast instead. For the expert is generally right, and the layman had better trust to the sortes Vergilianae than to his own judgment.

It is different with the other great department of school studies. The youth may never again see a test tube or a balance, but he cannot fail to be brought into contact with men. On no single occasion in his life may he ever have to draw an inference from his physical surroundings, but he can seldom escape the necessity of making up his mind about his fellow-creatures. His success in life will probably, will almost certainly, depend upon the ease and correctness with which he observes words, both written and spoken, and draws inferences from them $;^{1}$ he will on countless occasions need to analyse documents, to abstract them, and to compare them; he will seldom be freed from the necessity of inferring motives from actions and character from deeds; and it is precisely to these classes of mental operations, and to familiarity with these factors in human life, that school history, if properly conceived, and the history lesson, if properly conducted, will introduce him. If school is to educate for life, it appears that the department of social science is many times of greater value than that of physical science, and if this is so, a sound method for teaching history is of the first importance.

1 "By far the most important and comprehensive application of this class of inference (i.e. from an effect to its cause) takes place in the interpretation from words, gestures, and actions of the thoughts, feelings, and resolutions of other people, which indeed can be known in no other way."-Sigwart, Logic, Eng. Trans., vol. ii. p. 428 . 


\section{CHAPTER III}

CONTEMPORARY DOCUMENTS AS A BASIS OF METHOD

THE lack of uniformity, which is such a happy characteristic of English schools, makes it difficult to state with any certainty what are the modes of teaching history to middle forms at present most in vogue; and scattered through the body of teachers there are so many men of real capacity, that it is never safe to conclude that a given method, no matter how unlike those in common use, has not been employed somewhere, if it has in it any element of vitality. Indeed, with a subject like Education, in which so few records of practice have been kept, it is always possible that some one has been centuries in advance of contemporary practice. There is to hand, however, a work recently translated from the German by an English schoolmaster, with an introduction by a distinguished Professor of History, which gives a succinct account of the method probably adopted by many businesslike teachers. ${ }^{1}$

1 The Teaching of History, by Dr. Oscar Jaeger, translated by H. J. Chaytor, M.A., with an introduction by C. H. Firth, M.A., 1908. It is not out of place to state here that when this work appeared in Germany some fourteen years ago it was already old-fashioned, and probably represented with fairness only the more conservative type of German historical teaching. It is, however, a very characteristic production of sturdy conservatism, and well worth reading. 
The method that is under consideration by Dr. Jaeger as the most suitable for middle forms appears to be based on the employment of the text-book. "The use of the text-book (with the IV. Form) will not differ materially from that which obtains with the third. A section of the text-book will be read aloud at this stage by one pupil alone; one such reading will be sufficient. The master then goes through the narrative with all the stimulating detail that his dexterity and knowledge of the subject will allow him to introduce. The section or sections that have been thus worked through in form will then be read by the pupil at home. He will learn the facts so that he can repeat them when questioned by the master in the following lesson." 1 The text-book is, however, to be supplemented by a " narrative lecture." "The tone and character of the instruction is, however, determined by the teacher, and follows from his grasp of the subject, his manner of presenting it, and his mode of narrative; on these points the text-book should not prejudge his efforts. A style of lecture - teaching essentially informal, as it is natural and desirable at this stage of instruction, can be attained after some period of learning and practice. Our object at this moment is not to deal with a large mass of information in one lesson, but merely to expound such material as the text-book provides, and provides in sections of moderate length ; moreover, the teacher is perfectly well able, without exciting the surprise of the pupils, to glance at the textbook from time to time, if the thread of the argument escape him, as may well happen." ${ }^{2}$

It is not suggested that this sort of thing, if really well done, is of no value, but it may well be doubted if

1 op. cit. p. 77.

2 Ibid. p. 45. 
history teaching of this kind would be anything but a very inefficient substitute for the more rigorous training given by the traditional school subjects when well taught, and it is probable that the moral effect of such teaching will be far less than it well might be if a method which would induce more activity and more varied activity on the part of the pupil were used. The question to be answered is this: "How can history be made into a real training school for the mind, worthy of no inconsiderable place in the curriculum in schools where the classics are taught, and of a large place in modern schools and on modern sides where little or no classics are taught?"

For an answer to this question we must turn to the methods of the modern scientific historian. Our pupils can be given materials to work upon and plenty of them. The documents from which history has been written, and is to be written, are to be had for the asking. If only we make use of this material, if we fashion this new instrument to suit our needs, the problem of history teaching is by no means solved, but the avenue through which it may be attacked is opened up.

Our subject, then, must be reduced to problem form, and our pupils must be confronted with documents, and forced to exercise their minds upon them. A word of explanation is here needed. It is possible and suitable to derive a portion of our method from the scientific processes of the historian, but it must not be imagined that the aim is to convert schoolboys into historians. The boy is no more placed in the position of the historian who weighs and estimates his raw material, than the boy in the laboratory who is being put through a course of practical work is, to use the absurd phrase of the 
crank investigationist, being placed in the position of the scientific discoverer. Neither does the pupil, as the American votaries of the "source" method would have it, construct his own history and write his own text-book. What really takes place is widely different. The boy is given problems and exercises devised so that they suit his strength and cultivate certain activities and powers, and these exercises are of a highly artificial kind. They are as artificial in their relation to historical method as the exercises and proofs in the school algebra are to the mathematics of the engineer, the actuary, and the advanced mathematician. Scientific historical method shows the schoolmaster the way, his instinct and his experience direct him to the details of practice.

To persons of a simple and trusting disposition, to the habitual readers of the halfpenny press, and to Herbartian educationists of a certain type, everything that appears in print seems to be equally worthy of credence. Our pupils must not be allowed to remain in this blissful state of mind. We must lead them in the history lesson to apply the more simple criteria of accuracy and of sincerity, we must train them to read closely and to extract from a document all the internal evidence that is to be found there, to compare and to rationalise conflicting accounts of characters and of events ; and more important than all, though less showy, to summarise and to extract salient points from a series of loose, verbose, or involved statements. These exercises may involve little more than an almost mechanical process, or they may be devised so as to make demands upon the boy's whole ingenuity. Of whatever degree they may be, they necessitate class-room apparatus widely differing from the conventional text-book. 
Not that the text-book is to be discarded. Whatever method of teaching history is adopted, a summary of facts and dates, a sequence of events, a compendium of genealogies must be to hand. These things have to be learned by the beginner in history as paradigms have to be learned by the beginner in Greek. Neither in history nor in any other subject can a basis of memory-work be dispensed with. But the text-book is but half the apparatus, and it is a half that is not more than the whole. To complete it, and to give materials for exercises, contemporary documents must be supplied; and not merely brought into the class-room for illustrative purposes, to be used as an expansion of the text-book, but placed straight in the boy's hand for him to use his wits upon. ${ }^{1}$

When such documents are provided in the form either of graphed slips or of volumes of extracts or of both, they can be used in many ways. The following illustrations are not classified according to the different mental operations demanded, since this classification involves many difficulties, and is not very necessary for the present purpose. They are intended only to indicate a few types of exercises that can be varied to any extent by a competent teacher.

I. Conditions.-The class is reading the Reign of Richard II. and the Peasants' Revolt, but has not been introduced to any of the sources. They are given the following extract from Froissart, without any information as to its authorship :-

1 Some excellent compendia of documents illustrative of English History are already used by history teachers for atmospheric purposes. Colby's Selections from the Sources of English History, 1899, and Kendall's Source Book of English History, both of American origin, are excellent examples of such books. 


\section{Extract:-}

It is marvellous from what a trifle this pestilence raged in England. In order that it may serve as an example to mankind, I will speak of all that was done, from the information I had at the time on the subject.

It is customary in England, as well as in several other countries, for the nobility to have great privileges over the commonalty, whom they keep in bondage; that is to say they are bound by law and custom to plough the lands of gentlemen, to harvest the grain, to carry it home to the barn, to thrash and winnow it; they are also bound to harvest the hay and carry it home. All these services they are obliged to perform for their lords, and many more in England than in other countries. The prelates and gentlemen are thus served. In the counties of Kent, Essex, Sussex, and Bedford, these services are more oppressive than in all the rest of the kingdom.

The evil-disposed in these districts began to rise, saying they were too severely oppressed; that at the beginning of the world there were no slaves, and that no one ought to be treated as such, unless he had committed treason against his lord : but they had done no such thing, for they were neither angels nor spirits, but men formed after the same likeness with their lords, who treated them as beasts. This they would not longer bear, but had determined to be free, and if they laboured or did any other works for their lords, they would be paid for it.

A crazy priest in the county of Kent, called John Ball, who, for his absurd preaching, had been thrice confined in the prison of the Archbishop of Canterbury, was greatly instrumental in inflaming them with those ideas.

Exercise.-From the internal evidence write down everything that can be gathered about the author.

The points that a boy may reasonably be expected to get hold of are the following :-1

1 For this and for the following exercises the results noted as probable have been given to the writer by widely differing classes 
I. The writer was contemporary. From the information I had at the time on the subject.

2. He seems acquainted both with England and with Europe. It is customary in England as well as in several other countries.

3. He appears to know the situation in England very well. E.g. Reference to Kent, Essex, Sussex, and Bedford.

4. He seems to be on the side of the upper classes. The evil disposed in these districts.

5. But is at the same time sympathetic with the rebels.

6. He may have been a priest with conservative tendencies. A crazy priest, who for his absurd preaching.

General Inference.-He was either an Englishman who had travelled abroad, or a foreigner who had come to live in England. He may have been a man of humble birth who therefore knew the views of the poorer classes, attached as a secretary to some noble house. He may also have been a priest.

Here the answer is paragraphed, and the points are put as shortly as possible. This should be a characteristic of all answers to this type of question. The historical essay has its place, but these answers should not be given in essay form.

II. Conditions.-The class is working at the period of the Norman Conquest.

Extract:-

\section{W. M. on the Saxons}

The clergy, contented with a very slight degree of learning, could scarcely stammer out the words of the sacraments; a person who understood grammar was an object of wonder and

of boys. It is scarcely necessary to add that some preliminary training is needed before such exercises will be done well. 
astonishment. The monks mocked the rule of their order by their fine vestments, and the use of every kind of food. The nobility, given up to luxury and wantonness, went not to Church in the morning after the manner of Christians, but merely in a careless manner heard matins and masses from a hurrying priest in their chambers. . . . Drinking in parties was a universal practice, in which occupation they passed entire nights as well as days. They were accustomed to eat till they became surfeited, and to drink till they were sick.

\section{W. M. ON THE NoRMANS}

The Normans are proudly apparelled, delicate in their food, but not excessive. They are a race inured to war, and can hardly live without it ; fierce in rushing against the enemy, and where strength fails of success, ready to use stratagem or to corrupt by bribery. They live economically, but in fine houses; envy their equals and wish to excel their superiors, plunder their subjects, though they defend them from others; they are faithful to their lords, though a slight offence renders them perfidious. They weigh treachery by its chance of success, and change their sentiments with money. They are, however, the kindest of nations, and esteem strangers worthy of equal honour with themselves. They also intermarry with their vassals. They revived, by their arrival, the observances of religion, which were everywhere grown lifeless in England. You might see churches rise in every village, and monasteries in the cities, built after a style unknown before; each wealthy man accounted that day lost to him which he had neglected to signalise by some magnificent action.

Exercise.-(a) From internal evidence what may you conjecture about the writer?

(b) How far can these statements be trusted?

Here it does not seem likely that the same writer would be equally impartial as regards both the Saxons and the Normans; but William of Malmesbury, born of a Norman father and an English mother, and having lived in England before the Conquest, is a rather 
exceptional case, and his credibility affords material for an interesting discussion.

In both these exercises the same result is attained. The pupil is compelled ( 1 ) to read the document carefully ; (2) is given a definite object for reading it. If he has actually done so, it matters little if the result that he attains is meagre, or even if it is partially incorrect. He is being exercised in the categories of criticism, he has completed a school task, and the work thus done makes an excellent basis for a lesson upon the subject of the extract or upon some topic connected with it.

III. The next exercise is rather more complex. It involves a demand (A) to read and analyse a graphed slip, and (B) to illustrate it from an extract in the boys' extract book.

Conditions.-The class have been introduced to the enclosure of common lands in the reigns of Henry VIII. and Edward VI.

Extracts :-

A

The earth is Thine, O Lord, and all that is contained within; notwithstanding Thou hast given the possession thereof unto the children of men to pass over the time of their short pilgrimage in this vale of misery; we heartily pray thee to send Thy holy spirit into the hearts of them that possess the grounds, pastures, and dwelling-places of the earth; that they, remembering themselves to be Thy tenants, may not rack and stretch out the rents of their houses and lands, nor yet take unreasonable fines and incomes after the manner of covetous worldlings, but so let them out to other, that the inhabitants thereof may both be able to pay the rents, and also honestly to live, to nourish their families, and to relieve the poor. Give them grace also to consider that they are but strangers and pilgrims in this world, having here no dwelling-place, but seeking one to come; that they, remembering the short continuance of 
their life, may be content with that that is sufficient, and not join house to house, nor couple land to land to the impoverishment of other, but so behave themselves in letting out their tenements, lands, and pastures, that after this life they may be received into everlasting dwelling-places, through Jesus Christ our Lord. Amen. (The Primer; or, Book of Private Prayer, authorised by King Edward VI.)

\section{B}

1549.

Latimer's First Sermon, in Arber's Reprints,

p. 38. (Spelling modernised.)

.. You landlords, you rent-raisers, I may say you steplords, you unnatural lords, you have for your possessions yearly too much. For that heretofore went for $\mathrm{xx}$ or $\mathrm{xl}$ pound by year (which is an honest portion to be had gratis in one lordship, of another man's sweat and labour) now is it let for fifty or a hundred pound by year. Of this too much cometh this monstrous and portentous dearth made by man, notwithstanding God doth send us plentifully the fruits of the earth, mercifully, contrary unto our deserts; notwithstanding too much, which these rich men have, causeth such dearth, that poor men (which live of their labour) can not with the sweat of their face have a living, all kinds of victuals is so dear, pigs, geese, capons, chickens, eggs, etc.

These things with other are so unreasonably enhanced. And I think verily, that if this continue, we shall at length be constrained to pay for a pig a pound. I will tell you my lords and masters, this is not for the king's honour. Yet some will say: Knowest thou what belongeth unto the king's honour better than we? I answer that the true honour of a king is most perfectly mentioned and pointed forth in the Scriptures, of which, if ye be ignorant, for lack of time that ye cannot read it, albeit, that your counsel be never so politic, yet is it not for the king's honour. What his honour meaneth ye cannot tell. It is the king's honour that his subjects be led in the true religion. That all his prelates and clergy be set about their work in preaching and studying, and not to be interrupted from their charge. Also it is the king's honour that the common wealth be advanced, that the dearth of these 
foresaid things be provided for, and the commodities of this Realm so employed, as it may be to the setting his subjects on work, and keeping them from idleness. And herein rested the king's honour and his office ; so doing, his account before God shall be allowed and rewarded. Furthermore, if the king's honour (as some men say) standeth in the great multitude of people, then these graziers, enclosers, and rentrearers, are hinderers of the king's honour; for where there have been a great many of householders and inhabitants, there is now but a shepherd and his dog; so they hinder the king's honour most of all. My lords and masters, I say also, that all such proceedings are against the king's honour (as I have a part declared before), and as far as I can perceive, do intend plainly, to make the yeomanry slavery and the clergy slavery. For such works are all singular, private wealth and commodity. We of the clergy had too much, but that is taken away, and now we have too little. But for mine own part I have no cause to complain, for I thank God and the king I have sufficient, and God is my judge, I came not to crave of any man anything; but I know them that have too little. There lieth a great matter by these appropriations, great reformations is to be had in them. I know where is a great market-town with divers hamlets and inhabitants, where do rise yearly of their labours to the value of fifty pound, and the vicar that serveth (being so great a cure) hath but twelve or fourteen marks by year, so that of this pension he is not able to buy him books, nor give his neighbour drink; all the great gain goeth another way. My father was a yeoman and had no lands of his own, only he had a farm of three or four pound by year at the uttermost, and hereupon he tilled so much as kept half-a-dozen men. He had walk for a hundred sheep, and my mother milked thirty kine. He was able and did find the king a harness, with himself and his horse, while he came to the place that he should receive the king's wages. I can remember that I buckled his harness, when he went unto Blackheath field. He kept me to school, or else I had not been able to have preached before the king's majesty now. He married my sisters with five pound or twenty nobles apiece, so that he brought them up in godliness and fear of God. 
He kept hospitality for his poor neighbours. And some alms he gave to the poor, and all this did he of the said farm, where he that now hath it payeth sixteen pound by year or more, and is not able to do anything for his prince, for himself, nor for his children, or give a cup of drink to the poor. Thus all the enhancing and rearing goeth to your private commodity and wealth; so that where ye had a single too much, you have that; and since the same, ye have enhanced the rent, and so have increased another too much; so now ye have double too much, which is two too much. But let the preacher preach till his tongue be worn to the stumps, nothing is amended. We have good statutes made for the common wealth as touching commoners, enclosers; many meetings and sessions, but in the end of the matter there cometh nothing forth. Well, well, this is one thing I will say unto you, from whence it cometh $I$ know, even from the devil.

Exercise.-(a) From the prayer for landlords, state (I) what the landlords had done; (2) what were the results of the landlords' actions.

(b) Illustrate the actions and their results from Latimer's sermon.

The following answer might be expected :-

The landlords ( 1 ) had coupled land to land; (2) had increased rents of houses and lands; (3) had thus amassed unreasonable incomes.

As result, the small farmers were unable (4) to nourish their families; (5) to pay their rents and have something over ; 6 ) to relieve the poor.

Illustrations from Latimer's Sermon:-

I. Enclosers are hinderers of king's honour. Instead of many householders there are in some places now only a shcpherd and a dog.

2. Rents had been raised from $£ 50$ to $£$ I00. Prices of provisions had risen similarly. 
3. Landlords have double too much.

4. Latimer's father could educate his son and give his daughters a dowry. His successor could do nothing for his children.

5. Latimer's father had a horse and weapons, and fought at Blackheath. His successor could do nothing for his prince.

6. Latimer's father kept hospitality for his poor neighbours. His successor could not give a cup of drink to the poor.

A few actual answers given by boys to this question will indicate both that the exercise is within the compass of boys, and that for marking purposes it scatters the class.

(A) 1. The landlords possessing the pastures and dwelling-places of the earth had been racking and stretching out the rents of their houses and lands.

2. And had been taking unreasonable fines and incomes after the manner of covetous worldlings.

3. They had not been content, but had joined house to house and coupled land to land.

Results.-I and 2. The inhabitants were not able to pay the rents or to live honestly or nourish their families or to relieve the poor.

3. They had impoverished others.

Illustration from Latimer's Sermon :-

I. This causeth dearth, so that a poor man cannot obtain pigs, geese, etc., as everything is so dear. Some of the rents had been raised from $£ 4$ to $£ 8$. His father had a small farm and enough land for 100 sheep. With this he was able to send his boy to school, give alms to the poor, keep a horse and some armour, and so fight 
for the king. He also married his daughters with $£ 5$ apiece. But now a man that has the same cannot nourish his family or do good to the poor or any of the former things on account of the raising of the rent of the land.

2. Latimer's father used to pay $£ 3$ or $£ 4$ rent a year, but he who now has it has to pay $£ \mathrm{I} 6$ by year or more.

3. People had been enclosing the commons, the public grazing-grounds. So now people had to hire this ground from the large landowners.

(B) (a) From this prayer it appears that the landlords have done these things.

I. They have racked and stretched out the rents of their houses.

2. They have taken unreasonable fines and incomes after the manner of covetous worldlings.

3. They have joined houses to houses, and they have coupled land to land.

(b) The results of what the landlords have done are as follows :-

I. They have rendered it impossible for their tenants to pay their rents and also honestly to live, to nourish their families, and to relieve the poor.

2. They have impoverished their tenants.

Illustrations from Latimer's Sermon :-

(a) I. You have for your possession yearly too much, for what heretofore went for $£ 20$ or $£ 40$ by year now is let for $£ 50$ or $£ 100$ by year.

2. These rich men have caused such dearth.

3. These graziers, enclosers, and rent-rearers are hindrances of the king's honour, for where there have been a great many houscholders there is now but a shepherd and his dog. 
(b) I. Poor men cannot with the sweat of their face have a living, all kinds of victual are so dear. A farmer is not able to do anything for his prince, for himself, nor for his children, or give a cup of drink to the poor.

2. The tenants are so impoverished that they become vagrants.

(C) This boy mistakes the question or is careless, and gives the points of the prayer instead of stating what the landlords did.

(a) I. The prayer first of all asks that the landowners shall have the Holy Spirit not "to stretch out the rents of their houses and lands." A good many of the landowners did do to a large extent.

2. If they did not increase the rents " the inhabitants thereof might be able to both pay the rents and also honestly to live."

3. The third point in the prayer is that the landowners may be content with that which is sufficient, and that they may not be trying to get money from the poor and make themselves rich.

(D) This boy mistakes the question and thinks that the "results" asked for are the results of the prayer, in the efficacy of which he displays a touching confidence.

(a) What the landlords had been doing.

I. They had been racking and stretching out the rents of their houses and lands.

2. They had been taking unreasonable fines and incomes after the manner of covetous worldlings.

3. They had not been contented, and they coupled house to house and land to land.

(b) What the results were.

I. The inhabitants were able to pay rents.

2. They were able to nourish their families properly. 
3. They were able to live honestly.

4. They were also able to relieve the poor people.

5. They were very content indeed.

IV. This exercise took ten minutes in class at the close of a lesson. It was intended to prepare the way for the next history hour.

Conditions. - The class is doing the beginning of Mary's reign.

Extract:-

A SPeech of Queen Mary's to her Council upon her Resolution of Restoring Church Lands

1554 .

Somers' Tracts, i. 56.

We have willed you to be called to us, to the intent you might hear of me my conscience and the resolution of my mind, concerning the lands and possessions, as well of monasteries as other churches whatsoever, being now in my possession.

First, I do consider, that the said lands were taken away from the churches aforesaid in time of schism, and that by unlawful means, such as are contrary both to the law of God and of the Church : for which cause my conscience doth not suffer me to detain them. And therefore I here expressly refuse, either to claim or retain those lands for mine; but with all my heart, freely and willingly, without all faction or condition, here and before God, I do surrender and relinquish the said lands and possessions, or inheritances whatever; and renounce the same with this mind and purpose, that order and disposition thereof may be taken, as shall seem best liking to the Pope, or his legate, to the honour of God and the wealth of this our realm. And albeit you may object to me again, that the state of my kingdom, the dignity thereof, and my crown imperial cannot be honourably maintained and furnished without the possessions aforesaid ; yet notwithstanding-and so she had affirmed before, when she was bent upon the restitution of the tenths and first-fruits-I set more by the salvation of my soul than by ten such kingdoms : and therefore 
the said possessions I utterly refuse here to hold, after that sort and title; and I give most hearty thanks to God, who hath given me a husband of the same mind, who hath no less good affection in this behalf than I myself. Wherefore I charge and command that my chancellor, with whom I have conferred my mind in this matter, and you four to resort to-morrow together to the legate, signifying to him the premises in my name. And give your attendance upon me, for the more full declaration of the state of my kingdom, and of the aforesaid possessions, according as you yourselves do understand the matter, and can inform him in the same.

Exercise.-Read the extract carefully and state (I) Whose interests are not considered. (2) Which persons would not agree. (3) What comments you think these persons would have made upon Queen Mary's speech.

Some actual answers given by boys :-

(A) r. Mary merely mentions her own property. She entirely forgets the fact that the land had been given to the landowners and gentlemen.

2. The landowners and gentlemen would have thought Mary was doing wrong in giving land back to the Pope.

3. "Queen Mary considers her own land, but seems to forget we have land as well. She thinks it right to give it back, but all people do not think alike, and we desire to keep our land. Therefore, let Queen Mary give back only the land which belongs to her."

(B) I. The Queen does not refer to the Church lands that have been given away to the barons, large landowners, and farmers. She only refers to her own lands.

2. The barons, landowners, and all other people who had been given land by the King.

3. The landowners would have said that the King had rightly given them their land and now it was quite right for them to keep it. That they were Protestants and therefore did not wish to give land back to the Pope, who was head of the Roman Catholic Church. It was not lawful to take lands away when they had once been chosen by the Crown. 
(C) Here is an answer by an exceptionally stupid boy :-

I. The clergy and monasteries.

2. Cranmer, Latimer, and Ridley, because they would have said the Church of Rome was in schism and always had been, and so Mary was in the wrong.

V. The next exercise gives opportunity for close reading, and forms a good introduction to a treatment of the Court of High Commission.

Extracts:-

\section{(A) Act of Supremacy, I 559}

Most humbly beseech your most excellent Majesty, your faithful and obedient subjects, the Lords spiritual and temporal and the Commons in this your present Parliament assembled, that where in the time of your most dear father of worthy memory, King Henry the Eighth, divers good laws and statutes were made and established, as well for the utter extinguishment and putting away of all usurped and foreign powers and authorities out of this your realm ... as also for the restoring and uniting to the Imperial Crown of this realm the ancient jurisdictions and authorities ... to the same of right belonging to the intent that all usurped and foreign power and authority, spiritual and temporal, may for ever be clearly extinguished, may it please your Highness that it may be enacted that no foreign power, spiritual or temporal, shall at any time after the last day of this session of Parliament use any manner of power within this realm. And may it likewise please your Highness that such jurisdiction as hath heretofore been lawfully exercised for the reformation of all manner of errors, heresies, and schisms be united and annexed to the Imperial Crown of this realm, and that you shall have power to name and authorise persons to visit, reform, order, correct, and amend all such errors, heresies, and schisms . . . and that for the more sure observation of the Act, ... any person offending herein, being thereof lawfully convicted and attainted according to the due order and course of the Common Laws 
of this realm, shall forfeit unto your Highness all his goods and chattels, and if they be not of the value of twenty pounds shall besides the forfeiture suffer imprisonment by the space of one whole year.

\section{(B) ACT OF UNIFORMITY, I 559}

If any manner of parson, vicar, or other minister refuse to use the said Common Prayer in such order and form as they be set forth in the said book, and shall be thereof lawfully convicted according to the laws of this realm by verdict of twelve men, or by his own confession, or by the notorious evidence of the fact, he shall lose and forfeit to the Queen's Highness for his first offence, the profit of all his spiritual benefices coming in on a whole year next after his conviction.

\section{(C) First Commission, I 559}

We do give our full power and authority to you, or six of you ... to inquire into all offences committed contrary to the tenor of the said acts, and into all heretical opinions, seditious books, conspiracies, and misbehaviours . . . invented or set forth against us ... and you shall have full power and authority to award punishment to every offender by fine, imprisonment, or otherwise, and to take such order for the redress of the same as to your wisdom shall be thought meet and convenient

Witness, the Queen at Westminster,

PER IPSAM REgINAM. the 19 th day of July.

Exercise.-How far was the Queen empowered by the Acts of Supremacy and Uniformity (judged from the extracts given) to give her commissioners the powers granted in extract $\mathrm{C}$ ?

Two answers by boys :-

(A) It is extremely hard to say whether Elizabeth was justified in giving leave to fine and imprison offenders, and I myself do not think that it was a justifiable act on her part. 
In the Act of Supremacy the punishment enacted is that "Every person offending therein, being thereof lawfully convicted and attainted according to the due order and course of the Common Lawes of this realm, shall forfeit . . . his goods, and .... suffer imprisonment by the space of one whole year." This leave of Elizabeth's had nothing to do with the Common Law; it was anything but that. Also the Act of Uniformity only said that offenders should be fined, not imprisoned. Yet some people might say that Elizabeth's act was justified by the words, "And may it please your Highness that such jurisdiction as hath heretofore been lawfully exercised for the reformation of all manner of errors, heresies, and schisms be united and annexed to the Imperial Crown of this realm." But I think this is only a preliminary statement, and much depends on the meaning of the word "lawfully."

(B) By the Act of Supremacy Elizabeth received power to name and authorise persons to visit, reform, order, correct, and amend, but for fine and imprisonment a person had to be lawfully convicted according to the due order of the Common Law.

By the Act of Uniformity persons who were fined had to be "convicted according to the laws of this realm by verdict of twelve men." It said nothing about six men privately appointed by Elizabeth.

VI. Henry V.'s dying instructions give an opportunity for making some remarks on character.

Conditions. - The class have been told that Henry's claim to the throne was quite unjustified, and that Henry himself when declaring war can hardly have thought otherwise.

\section{Extract:-}

August 1422.

Thomas de Elmham, Vita Henrici Quinti, ed. Hearne, p. 333. (Latin contemporary.)

Three days before his death, having summoned into his presence the Dukes of Bedford and Exeter and other nobles of his household, he spoke tranquilly to them as follows: 
"It is certain," he said, "that I cannot escape death, which is already near at hand. If, therefore, during my reign I have ruled otherwise than I ought, or have done any one injustice, of which I believe the contrary, as a suppliant I pray for pardon. For your good services, especially in these wars, I give thanks to you and to all your fellow-soldiers; for which, if death had not prevented me, I intended to reward each according to his deserts. I command you to continue the wars until peace is made, to which, I declare before God, I was drawn neither by the ambitious lust for power, nor for vainglory, nor for worldly honour, nor for any other such cause, but solely that by pursuing my last claim I might obtain at once peace and right. To my brother the Duke of Bedford I decree that the custody and government of the duchy of Normandy shall be committed until my son reaches years of discretion. But the protector and defender of England shall be my brother, the Duke of Gloucester. My uncle the Duke of Exeter, my Chamberlain, and Hungreford, Seneschal of my household, I wish and desire to be in attendance on the person of my son.

Exercise.-What light does this extract throw upon (1) Henry's character? (2) His opinion of his brothers? The answers to this exercise separate the more clever from the less clever boys. The latter boldly state that Henry was a liar, and get no marks for the statement; the former point out that it is unlikely that he would lie deliberately upon his death-bed and that, although at the beginning he cannot have believed in his claim, his success in war coupled with his power of self-deception must have convinced him of the justice of his cause.

VII. The following exercise similarly compels the pupil to consider character closely and at the same time lends itself to a revision of back work.

Conditions. - The class have completed the reign of 
Henry II., and are acquainted with the leading features of his character.

Extracts:-_1

(a) By Peter of Blois.

He does not lie idle in his palace like other kings, but makes rapid journeys through the provinces, finding out what every one is doing, No one is more acute in deliberation; no one has a greater torrent of eloquence. Whenever he has a breathing space from his duties and anxieties he occupies himself in private reading, or elaborates some problem in the call of an ecclesiastic. Our king is a man of peace, but he is as successful in war as he is magnificent in peace. The one object of his desires in this world was the peace of his people, and this he has given them. No one is kinder to the afflicted, or more affable to the poor, and no one made himself more insufferable to the proud. As it were in imitation of the Divinity his object always was to humble the mighty, to raise up the oppressed, and to set in operation continual persecution and destruction against those who swelled with pride.

(b) By Ralph Niger.

When he came to the throne he appointed slaves, bastards, and vagabonds to the chief offices in his kingdom. Illustrious men who were accused of crimes of a moral character but were otherwise irreproachable he deprived entirely of their estates or annihilated them by gradually stealing bits of their property. He made bishops and abbots of the servants of his households or of the jesters at court. He made an unheardof law about the forests by which those who had committed no other breach of law suffered perpetual punishment. $\mathrm{He}$ prevented men of high position from marrying or giving in marriage without his leave, and those who transgressed he punished as traitors. He kept for his own use or sold other peoples' inheritances. In deciding to which courts cases should go he showed a pettifogging spirit, and even sold decisions.

1 Paraphrased from passages quoted by Stubbs, Constitutional History of England, vol. i. p. 535. 
Exercise.-Describe Henry's character and show how the various elements in it will admit of interpretations that differ as widely as the above, according to the friendly or hostile disposition of the writer.

VIII. Exercises in character may easily be made more complex.

Conditions. - The class may have been told something about Clarendon, they have some acquaintance with Milton's political views, and they know that Eıkon Basilike was a partisan pamphlet.

Extracts:-

$$
\begin{aligned}
& \text { A } \\
& \text { C40. Clarendon, History of the Rebellion, } \\
& \text { i. 227. (Before 1672.) }
\end{aligned}
$$

The Earl of Strafford had for the space of almost six years entirely governed Ireland, where he had been compelled, upon reason of state, to exercise many acts of power; and had indulged some to his own appetite and passion.

He was a man of too high and severe a deportment, and too great a contemner of ceremony, to have many friends at court, and therefore could not but have enemies enough.

He had an enemy more terrible than all the others, and like to be more fatal, the whole Scottish nation, provoked by the declaration he had procured of Ireland, and some high carriage and expressions of his against them in that kingdom. So that he had reason to expect as hard measure from such popular councils as he saw were like to be in request, as all those disadvantages could create towards him. And yet, no doubt, his confidence was so great in himself and in the form of justice (which he could not suspect would be so totally confounded), that he never apprehended a greater censure than a sequestration from all public employments, in which it is probable he had abundant satiety: and this confidence could not have proceeded (considering the full knowledge he had of his judges) but from a proportionable stock, and satisfaction, in his own innocence. 
B

Eikon Basilike, p. 8.

(Contemporary.)

I looked upon my Lord of Strafford as a gentleman whose great abilities might make a prince rather afraid than ashamed to employ him in the greatest affairs of state.

For those were prone to create in him great confidence of undertakings, and this was like enough to betray him to great errors and many enemies; whereof he could not but contract good store, while moving in so high a sphere and with so vigorous a lustre, he must needs, as the sun, raise many envious exhalations, which condensed by a popular odium, were capable to cast a cloud upon the brightest merit and integrity.

Though I cannot in my judgment approve all he did, driven it may be, by the necessities of times and the temper of that people, more than led by his own disposition to any height and rigour of actions; yet I could never be convinced of any such criminousness in him as willingly to expose his life to the stroke of justice, and malice of his enemies.

I never met with a more unhappy conjuncture of affairs than in the business of that unfortunate earl; when between my own unsatisfiedness in conscience, and a necessity, as some told me, of satisfying the importunities of some people, I was persuaded by those that I think wished me well to choose rather what was safe than what seemed just, preferring the outward peace of my kingdoms with men before that inward exactness of conscience before God.

And, indeed, I am so far from excusing or denying that compliance on my part (for plenary consent it was not) to his destruction, whom in my judgment I thought not, by any clear law, guilty of death, that I never bare any touch of conscience with greater regret; which, as a sign of my repentance, I have often with sorrow confessed both to God and men as an act of so sinful frailty, that it discovered more a fear of man than of God, whose name and place on earth no man is worthy to bear, who will avoid inconveniences of state by acts of so high injustice as no public convenience can expiate or compensate. 
Nor were the crimes objected against him so clear, as after a long and fair hearing to give convincing satisfaction to the major part of both Houses, especially that of the Lords, of whom scarce a third part were present when the bill passed that House. And for the House of Commons, many gentlemen, disposed enough to diminish my Lord of Strafford's greatness and power, yet unsatisfied of his guilt in law, durst not condemn him to die; who, for their integrity in their votes, were, by posting their names, exposed to the popular calumny, hatred, and fury, which grew then so exorbitant in their clamours for justice (that is to have both myself and the two Houses vote and do as they would have us), that many, it is thought, were rather terrified to concur with the condenıning party than satisfied that of right they ought so to do.

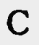

Milton, Eikonoklastes, p. I4.

(Contemporary.)

This next chapter is a penitent confession of the king, and the strangest, if it be well weighed, that ever was auricular. For he repents here of giving his consent, though most unwillingly, to the most seasonable and solemn piece of justice that had been done of many years in the land: but his sole conscience thought the contrary. And thus was the welfare, the safety, and within a little, the unanimous demand of three populous nations to have attended still on the singularity of one man's opinionated conscience; if men had been always so tame and spiritless, and had not unexpectedly found the grace to understand, that if his conscience were so narrow and peculiar to himself, it was not fit his authority should be so ample and universal over others. For certainly a private conscience sorts not with a public calling; but declares that person rather meant by nature for a private fortune. And this also we may take for truth, that he whose conscience thinks it sin to put to death a capital offender, will as oft think it meritorious to kill a righteous person. But let us hear what the sin was that lay so sore upon him, and, as one of his prayers given to Dr. Juxon testifies, to the very day of his death; it was his signing the bill of Strafford's execution: 
a man whom all men looked upon as one of the boldest and most impetuous instruments that the king had to advance any violent or illegal design. $\mathrm{He}$ had ruled Ireland, and some parts of England in an arbitrary manner, had endeavoured to subvert fundamental laws, to subvert parliaments, and to incense the king against them; he had also endeavoured to make hostility between England and Scotland: he had counselled the king to call over that Irish army of papists, which he had cunningly raised, to reduce England, as appeared by good testimony then present at the consultation. For which, and many other crimes alleged and proved against him in twenty-eight articles, he was condemned of high treason by the parliament. The Commons by far the greater number cast him; the Lords, after they had been satisfied in a full discourse by the king's solicitor, and the opinions of many judges delivered in their house, agreed likewise to the sentence of treason. The people universally cried out for justice.

Exercise.-How far were writers of different political views in agreement as to the more striking features of Strafford's character?

IX. Conditions. - The class have just finished the battle of Agincourt.

Extracts:-

A

Monstrelet, Chroniques, liv. i., ch. clviii.

(French contemporary, shortened.)

The said Duke of Burgundy, from Lagny-sur-Marne, sent to Paris to the [French] king and his Council, asking that he might enter Paris with all his host for safety; but the only reply vouchsafed to him was that if he would enter unattended, the king and his Council would be satisfied, and not otherwise. This the Duke of Burgundy would never have done, for he knew well that those who advised the king were his mortal enemies, and he would on no account trust himself to them. 
B

1416.

Jean Juvenal des Ursins, p. 534. (French contemporary, shortened.)

The Duke of Burgundy then sent very seditious letters to many of the "good towns" to gain them over from their allegiance to the king. And he sent to Rouen, which suddenly declared its allegiance to him. The towns of Rheims, Chalons, Troyes, and Auxerre also joyfully submitted themselves, and took the cross of St. Andrew, and said, "Long live Burgundy!" After their submission they took the men who had formerly been the king's officers, and cut off their heads, and robbed them of their goods. And to kill a man it was sufficient to say: "He is an Armagnac." Similarly, when any were found who were known to belong to the faction of the Duke of Burgundy, they were punished, and their goods seized.

$1417,1418$.

\section{C}

Journal d'un Bourgeois de Paris, ed. Buchon, p. 625. (French contem. porary.)

Item, at this time, at the beginning of August, the Duke of Burgundy prepared to come to Paris, and he approached, subduing [on his way] towns, cities, and castles, and proclaiming everywhere in the name of the king, and the dauphin, and in his own name, that no one should pay taxes; wherefore the governors of Paris conceived such great hatred against him that they caused preachers to say that they well knew that he wished to be king of France, and that it was through him and his advice that the English were in Normandy ; and in every street in Paris dwelt spies, who arrested and imprisoned their very neighbours; and no man after he had been arrested dared speak about it, for fear of losing his goods or his life.

[On May 28 the Burgundian forces assaulted Paris. The Parisians rose in revolt, and a general massacre took place.]

Then there was a great commotion in Paris. The people took up arms and approached the bands of the Burgundians before the soldiers were assembled. Then the new prefect of Paris came, and with his own followers, and with the help of 
the Commons, repulsed the Burgundians, striking down and killing a great heap outside the gate of St. Anthony ; and then the people, being much incensed against the Burgundians, went to all the hostelries in Paris seeking them, and when they found one, whatever were his condition, prisoner or free, he was led out to the soldiers in the middle of the street, and mercilessly slain with great axes and other weapons. And, when they were all lying dead, the women and children, having no power to do them further ill, cursed them as they passed, saying, "Dogs of traitors, you fare better than you deserve." And you could not find a single street of any importance in Paris where there had not been some massacre, nor could you walk a hundred paces for the dead that were there. And on that Sunday, the $29^{\text {th }}$ day of May, there were slain in the streets of Paris, by the sword and other weapons, $522 \mathrm{men}$, without counting those slain within the houses.

Exercise.-From the extracts quoted estimate the effect produced by the campaign of Agincourt upon the relations of political parties in France.

Two answers by boys who had not much experience of this kind of work :-

(A) Henry's successes in France do not seem to have made the rival parties in France join together, as they should have done, against a common enemy. The French king was not able to keep his subjects under control. This is shown by the massacre which took place upon the Duke of Burgundy's entry into Paris. Men went about doing just whatever they pleased.

(B) In France at this period there were two rival parties: the Burgundians and the Orleanists or Armagnacs, of whom the latter at present were on the king's side. The Duke of Burgundy was afraid that his cause might be harmed, and so sent to Paris to ask for protection; this being refused unless he came alone, he resolved on another plan, viz. : He saw that the king, and therefore his rivals also, were weak on account of the recent wars, so he determined to storm Paris and capture the king. However, he failed in doing this, and his force was 
badly mauled, over 500 being killed in the streets of Paris. Thus these campaigns caused civil wars and other bloodshed besides what they entailed themselves.

An answer by a boy of the same type and age (13-14) who had worked for a year at exercises of this kind :-

(C) I. "Those who advised the king were his (the Duke of Burgundy's) mortal enemies" still after the campaign of Agincourt. In other words, pressing danger did not, as might have been thought, unite them.

2. The disorganisation seems indeed to have increased; for a number of towns in important positions in France joined Burgundy. The feuds became even more brutal; each side killed the other whenever they could.

3. But in Paris the Armagnacs still seem to have been able to appeal to the patriotism of their followers, and their statement that Burgundy had invited the English over may have been largely responsible for the massacre of 9 th May.

It will be noticed that $C$ shows a considerable advance on $\mathrm{B}$ and $\mathrm{A}$ in both conciseness and appositeness.

$\mathbf{X}$. The next exercise is a harder one, suitable for boys who have worked for some years on these lines. A full discussion in class of the points to look out for might be needed before the pupils are set to work upon it; indeed this remark applies to all exercises of this kind. The most suitable problem may be made unsuitable for a given class by the omission of sensible precautions or the withholding of necessary data.

Conditions.-The class have a good knowledge of the legislation of Edward I.'s reign.

\section{Extract:-}

Dugdale's Monasticon, vol. i. p. 394 .

To all the faithful of Christ to whom the present writing shall come, Richard by the divine permission abbot of Peterborough and the Convent of the same place, eternal greeting 
in the Lord. Let all know that we have manumitted and liberated from all yoke of servitude William, the son of Richard of Wythington, whom previously we have held as our born bondman, with his whole progeny and all his chattels, so that neither we nor our successors shall be able to require or exact any right or claim in the said William, his progeny or his chattels. But the same William with his whole progeny and all his chattels will remain free and quit and without disturbance, exaction, or any claim on the part of us or our successors by reason of any servitude, forever. We will, moreover and concede that he and his heirs shall hold the messuages, land, rent and meadows in Wythington, which his ancestors held from us and our predecessors, by giving and performing the fine for giving his daughter in marriage, that he shall have and hold these for the future from us and our successors freely, quietly, peacefully, and hereditarily, by paying thence to us and our successors yearly 4 os. sterling, at the four terms of the year. And if it shall happen that the said William or his heirs shall die at any time without an heir, the said messuage, land, rents and meadows with their appurtenances shall return fully and completely to us and our successors. Nor will it be allowed to the said William or his heirs, the said messuage, land, rents, meadows or any part of them to give, sell, alienate, mortgage, or in any way encumber by which the said messuage, land, rents and meadows should not return to us and our successors in the form declared above.

Exercise.-From the internal evidence to give the approximate date of this deed.

The key to the answer is to be found in the last paragraph.

Nor will it be allowed to the said William or his heirs, the said messuage, land, rents, meadows or any part of them to give, sell, alienate, mortgage, or in any way encumber by which the said messuage, land, rents and meadows should not return to us and our successors as in the form declared above.

This clause would be unnecessary after the Statute of 
Quia Emptores (1290). It attempts to do privately what later on was done by the Statute. The document may therefore be ascribed to a date earlier than 1290 . Its date is actually 1278 .

XI. The next exercise introduces the class to the value of letters for evidential purposes. If written $a$ cour ouvert they may be taken as expressing the real views of the writer, who none the less may be in error as to his facts. In many cases, however, the sentiments expressed have to be discounted.

Conditions. - The class are doing the reign of Elizabeth, and have reached the execution of Mary Queen of Scots. They have a good knowledge of the general political situation.

\section{Extract:-}

My DEAR BRother,-I would you knew (though not felt) the extreme dolor that overwhelms my mind, for that miserable accident which (far contrary to my meaning) hath befallen. I have now sent this kinsman of mine whom ere now it hath pleased you to favour, to instruct you truly of that which is too irksome for my pen to tell you. I beseech you that as God and many more know, how innocent $I$ am in this case : so you will believe me that if I had directed ought I would have abided by it. I am not so base-minded that fear of any living creature or prince should make me afraid to do that were just, or make me to deny the same. I am not of so base a lineage, nor carry so vile a mind. But, as not to disguise, fits not a king, so will I never dissemble my actions, but cause them show even as I meant them. Thus assuring yourself of me, that as I know this was deserved, yet if I had meant it I would never lay it on others' shoulders; no more will I not damnify myself, that thought it not.

The circumstance it may please you to have of this bearer. And for your part, think you have not in the world a more loving kinswoman, nor a more dear friend than myself; nor 
any that will watch more carefully to preserve you and your estate. And who shall otherwise persuade you, judge them more partial to others than you. And thus in haste I leave to trouble you : beseeching God to send you a long reign.Your most assured loving sister and cousin,

The $14^{\text {th }}$ of February 1586.

Elizab. R.

Exercise--(I) Make a brief analysis of the letter. (2) State which of the points in it express the real views of the writer and which do not. Give your reasons.

Here various opinions might be held as to the first part of the letter, but there is no reason to believe that the second part is not a true expression of sentiment.

XII. Accounts of battles, especially if two conflicting accounts can be found, give abundant opportunities for the comparison of conflicting testimony.

Conditions.-The class are reading the reign of Edward II., and are about to have a lesson on his Scotch campaign. They have maps of England and Scotland, but not a plan of the battle of Bannockburn.

Extracts :-

A

1314.

Translated from Latin of

Chronicle of Lanercost, 225-228.

(Circ. 1345.)

Now before the festival of the Nativity of St. John the Baptist, the king collected the whole of his army into one host, and with the aforesaid array drew nigh to the castle of Stirling to raise the siege, and to fight with the Scots who were assembled there in force; and on St. John's Eve after dinner the king's army came to Torr Wood ; and when it was heard that the Scots were in the wood, the king's vanguard, led by Lord Clifford, wished to surround the wood, to prevent the Scots from escaping by flight. Now the Scots suffered this, till the English were completely cut off from their friends, and 
then they showed themselves and charged that vanguard; some they slew and the rest they put to flight, and from that hour there was fear among the English, and greater boldness on the part of the Scots.

On the following day - a dark day for England, unlucky and ill-omened-when either side was preparing for battle, the English archers advanced in front of their line, and were met by Scottish archers. On either side some were wounded and some killed; but the English archers soon put the others to flight. Now when the two armies had drawn very near together, all the Scots knelt down and said a "paternoster," and commended themselves to God, and asked help of heaven; and thereafter they boldly marched against the English. They had so arranged their host that two lines were in front of the third, side by side, in such a way that neither marched in front of the other; and the third line was in the rear, and there was Robert. Now when both armies met and the English chargers galtoped against the Scottish spears, as against a thick wood, there arose an exceeding great and terrible noise from the breaking of spears, and from chargers mortally wounded; and so they halted for a space. But the English in the rear could not reach the Scots because of their vanguard in between, and they could in no way help themselves, and so nothing remained but to arrange for flight. And this account I heard from a credible witness who was there present and saw what happened. In that vanguard were slain the Earl of Gloucester, Sir Robert Clifford, Sir John Comyn, Sir Payen de Typetot, Sir Edmond de Mauley, and many other nobles - to make no mention of the infantry who fell in great numbers. Moreover, another misfortune occurred to the English, because, after crossing a great pit, into which the tide flows, and which is called the Bannockburn, they fell into confusion and wished to retreat; but many nobles and others, on account of the press, fell in with their horses; some with great difficulty escaped, but many could never get out of the pit; and so the name of Bannockburn was familiar to the English for many years to come.

Now the king and Sir Hugh Despenser, who after Piers Gaveston was his chief favourite, and Sir Henry Beaumont, 
together with many other horse and foot, with a Scottish knight for guide, who knew by what route they could escape, to their everlasting shame fled like cravens towards the castle of Dunbar. Some, however, more tardy in their flight, were slain by the Scots, who followed hard in pursuit. At Dunbar the king, with some of his more immediate followers, put out in a boat towards Berwick, leaving all the rest to their fate, but they arrived safe and sound in England in due course. . . . After this victory Robert Bruce was unanimously called king of Scotland, because he had won Scotland by force of arms.

B

Translated from Latin of Baker of Swinbrook, 146.

(Circ. 1358.)

On that night (June 23) you might have seen the English host deep in their cups, wassailing and toasting immoderately; on the other hand the Scots silently kept the vigil fasting, their every thought centred in their desire for their country's freedom; and this desire, though ungrounded, was vehement and equal to all risks. On the morrow the Scots seized the most advantageous position, and dug pits three feet deep and as wide across, stretching along the whole line from the right wing to the left; these they covered over with a light framework of twigs and osiers, that is to say with hurdles ; and then over the top they strewed turf and grass; so that men could cross them on foot with care, but they could not support the weight of cavalry. In accordance with their royal leader's commands none of the Scots were mounted, and their army, drawn up in the usual divisions, was posted in solid formation at no great distance from this pit which had been warily, not to say craftily, set between themselves and the English. On the other side, as the English army advanced from the west, the rising sun flashed upon their golden shields and polished helms. Their vanguard consisted of light horse and heavy cavalry, all unconscious of the Scots' pit with its cunningly contrived light covering; in the second division were men-atarms and archers held in reserve to give chase to the enemy; in the third was the king with the bishops and other church- 
men, and among them the brave knight Hugh Spenser. The cavalry of the vanguard advanced against the enemy, and fell headlong as their horses stumbled into the ditch with their fore-feet caught in the broken hurdles; and when these fell through, the enemy came up and slew them, giving quarter only to the rich for ransom. . . . And in this disaster some were slain by our archers who had not had a proper position assigned to them, but formerly stood in the rear of the menat-arms, whereas now they take up their position on the flank. When they saw the Scots fiercely attack those who had fallen into the ditch, some aimlessly aimed their arrows into the air, on the chance of falling in the joints of the enemy's armour, and some shot straight at the Scots and hit a few of them in the breast, but at the some time struck many more of the English in the back. So came to nothing the pomp of the day before, for the king with the bishops and De Spenser took the precaution of flight.

Exercise.-To draw a plan of the battle of Bannockburn from the two accounts.

For a certain stage it would be well to ask the pupils to draw three maps: (I) of the battle as described in extract A ; (2) of the battle as described in extract B; (3) a combination of the two.

I. The boys know the position of Stirling, and they realise roughly from which direction the English are marching. : They should consequently be able to determine the position of Torr Wood as south of Stirling and on the line of march of the English army. The arrangement of the Scotch army can be gathered, as also the disadvantageous disposition of the English. It is not difficult to infer that the Bannockburn would be between the opposing parties, as the Scotch would certainly draw up their forces on the side away from the English. We thus get the following plan:- 


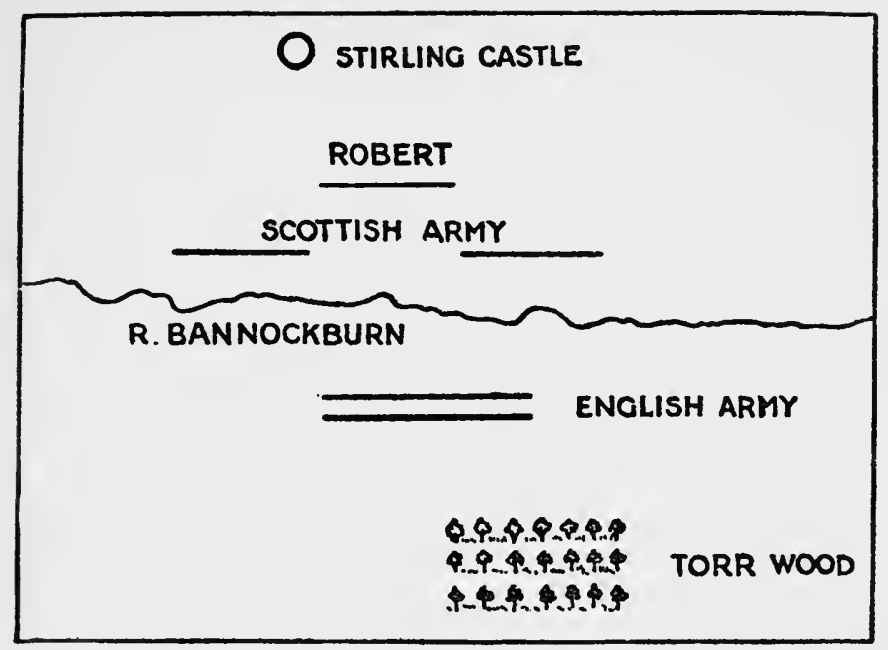

2. In this account are given the pits dug by the Scotch, and a more detailed version of the position of the English. It also appears, from the statement that "the English army advanced from the west," that Torr Wood may have to be shifted westward.

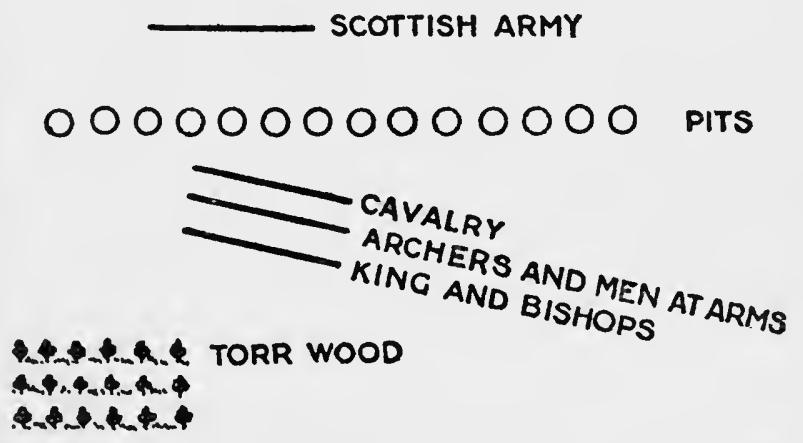


3. The two plans can now be combined, giving the following result :--

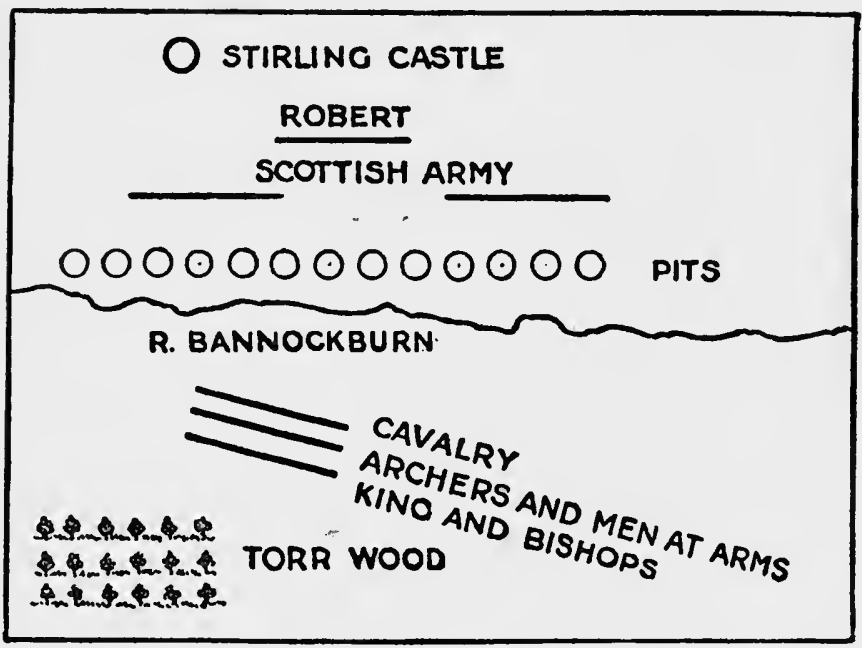

4. Finally the accepted plan of the battle may be placed on the blackboard and copied into the boys' notebooks.

XIII. The following exercise is of a similar kind, but considerably harder. The battle described is Poitiers.

\section{Extracts:-}

\section{A}

1356. Translated from Latin of Baker of Swinbrook, 7.

(Circ. 1358.)

The prince perceived that there was a hill on his flank, set round with hedges and ditches, but open towards the centre; on the one side was pasture land and thick scrub, on the other vineyards; the rest was ploughland; and it was upon the 
ploughed crest of this hill that he imagined the French host lay. Between us and the hill was a broad steep valley, and a marsh with a stream running through it. The prince's division with the baggage waggons crossed the stream at a narrow ford, and leaving the valley got across the intervening hedges and ditches, and took possession of the hill, where he was concealed by the nature of the ground among the thickets, while at the same time commanding the enemy. The ground occupied by our first and second divisions was separated from the open space held by the French by a long hedge and ditch, one end of which stretched down to the marsh mentioned above. The marsh end of the slope was held by the Earl of Warwick, the leader of the van. At the top of the long hedge there was an open break or gap made by the harvest waggons; and a stone's throw distant was our rearguard, under the Earl of Salisbury.

The enemy seeing the prince's banner just displayed and then suddenly moved forward and then, owing to the hill in between, removed from their sight altogether, thought that he was making off, in spite of the protests of Douglas of Scotland and the Marshal of Claremont that this was not the case; accordingly they begin the advance. ... In the meantime, Claremont, thinking to get through the break in the hedge and encompass our vanguard in the rear, fell in with the Earl of Salisbury, who, seeing Claremont approach, shrewdly suspected his intention; and so the commander of our rearguard, purposing to seize the gap with all haste and head off the enemy's passage, was constrained to sustain the first attack. Then began a terrible struggle between the men-atarms, fighting with spears, swords, and axes. Nor were the archers failing in their duty, but lying in safe entrenchments and shooting from above the ditch and over the hedge they did more execution than the men-at-arms; and continuous showers of bolts were discharged by the cross-bowmen.

The Earl of Oxford now came up from the prince's division and had the archers deployed on to the enemy's flank, with orders to shoot at the hindquarters of their horses; and by this means the wounded horses reared and threw their riders, and galloping back to their own side did no small harm to 
their masters, who had devised quite another scheme. . . . Thereupon

[after the defeat of the enemy's first line]

our men retired to order their ranks and our vanguard and middle division joined forces.

Immediately the French second line advances, under the king's eldest son, the Dauphin. . . . It soon becomes a handto-hand engagement, and every man for his own life strives to deal death to his foe. And although this division offered us a more stubborn resistance than the former, yet, after a great number on their side had been slain, they made an honourable retreat.

[The first and second line being disposed of, the French king advances in person to the attack.]

Then the prince ordered his standard-bearer, Sir Walter Woodland, to advance against the foe; and with a few fresh men he went to meet the king's great army. ... Then a formidable body of cross-bowmen with thick clouds of bolts darken the air, that now resounds with the deadly hail of arrows shot by the English, in the frenzy of despair. Moreover, ashen darts are thrown at the enemy from long range; but the dense mass of the French in close order protect themselves with shields locked together and keep off the missiles; thus the archers had emptied their quivers in vain and armed only with swords and bucklers must attack troops in heavy armour, for they are resolved to sell life dearly.

[When the prince is making his last desperate stand, the Captal de Buch takes the enemy in the rear.]

. . Here they find a stout and stubborn resistance. The English fall to, so do the French; their king, albeit of youthful years yet, performs great feats; but at length, by a swift turn of fortune's wheel, the Prince of Wales dashes upon the foe, and breaking their pride, spares the vanquished, and takes the king prisoner. 
B

1356.

Froissart, cc. 160-166.

(I 369-73.)

On the Sunday the French king called to him the Lord Eustace Ribemont, the Lord John of Landas, and the Lord Richard of Beaujeu, and said to them : "Sirs, ride on before to see the dealing of the Englishmen, and advise well what number they be and by what means we may fight with them, either a-foot or a-horseback." These three knights rode forth, and the king was on a white courser, and said to his men: "Sirs, among you when ye be at Paris, at Chartres, at Rouen, or at Orleans, then ye do threat the Englishmen and desire to be in arms out against them. Now ye be come thereto; I shall now show you them; now show forth your evil will that ye bear them, and revenge your displeasures and damages that they have done you, for without doubt we shall fight with them." Such as heard him said: "Sir, in God's name so be it ; that would we see gladly."

Therewith the three knights returned again to the king, who demanded of them tidings. Then Sir Eustace of Ribemont answered for all and said: "Sir, we have seen the Englishmen; by estimation they be two thousand men of arms and four thousand archers and fifteen hundred others. Howbeit they be in a strong place, and as far as we can imagine they are in one battle; howbeit they be wisely ordered, and along the way they have fortified strongly hedges and bushes; one part of their archers are along by the hedge, so that none can go nor ride that way, but must pass by them, and that way must ye go an ye purpose to fight with them. In this hedge there is but one entry and one issue by which four horsemen may ride abreast. At the end of this hedge, where no man can go nor ride, there be men of arms afoot and archers before them in manner of a harrow, so that they will not be lightly discomfited." "Well," said the king, "what will ye then counsel us to do?" Sir Eustace said: "Sir, let us be all afoot, except three hundred men of arms, well horsed, of the best in your host and most hardiest, to the intent that they break somewhat and open up the archers; and then let your 
battles follow on quickly afoot and so fight with their men of arms hand to hand. This is the best advice that I can give you : if any other think any other way better, let him speak."

The king said: "Thus shall it be done."

[On the eve of battle the Cardinal of Perigord came to the French king to try and arrange terms of peace; nothing came of it, for the terms he was allowed to offer the English were rejected.]

That night the Frenchmen took their ease; they had provision enough, and the Englishmen had great default; they could get no forage, nor could they depart thence without danger of their enemies. That Sunday the Englishmen made great dykes and hedges about their archers to be the more stronger ; and on the Monday in the morning the prince and his company were ready apparelled as they were before, and about the sun-rising in like manner were the Frenchmen.

When the prince saw, that he should have battle he said to his men: "Now, sirs, though we be but a small company, as in regard to the puissance of our enemies, let us not be ashamed therefor; for the victory lieth not in the multitude of people, but where God will send it. If it fortune that the journey be ours, we shall be the most honoured people of all the world; and if we die in our right quarrel, I have the king, my father, and brethren, and also ye have good friends and kinsmen; these shall revenge us. Therefore, sirs, for God's sake, I require you do your devoirs this day; for if God be pleased and Saint George, this day ye shall see me a good knight." These words and such other that the prince spoke comforted all his people. . . .

Then the battle began on all parts, and the battles of the marshals of France approached, and they set forth that were appointed to break the array of the archers. They entered a-horseback into the way where the great hedges were on both sides set full of archers. As soon as the men of arms entered, the archers began to shoot on both sides, and did slay and hurt horses and knights, so that the horses when they felt the sharp arrows would in no wise go forward, but drew aback and shied and took on so fiercely, that many of 
them fell on their masters, so that for press they could not rise again; insomuch that the marshals' battle could never come at the prince. Certain knights and squires that were well horsed passed through the archers, and thought to approach to the prince, but they could not. . . . The battle of the marshals began to disorder by reason of the shot of the archers with the aid of the men of arms, who came in among them and slew of them, and did what they list. . . . So within a short space the marshals' battles were discomfited, for they fell one upon another and could not go forth; and the Frenchmen that were behind and could not get forward recoiled back and came on the battle of the Duke of Normandy, which was great and thick and on foot; but anon they began to open behind; for when they knew that the marshals' battle was discomfited they took their horses and departed, he that might best. Also they saw a rout of Englishmen coming down a little mountain a-horseback, and many archers with them, who brake in on the side of the duke's battle. True to say the archers did their company that day great advantage; for they shot so thick that the Frenchmen wist not on what side to take heed, and little by little the Englishmen won ground on them.

And when the men of arms of England saw that the marshals' battle was discomfited, and that the duke's battle began to disorder and open, they leapt then on their horses, which they had ready by them; then they assembled together and cried : "Saint George ! Guienne!" and the Lord Chandos said to the prince: "Sir, take your horse and ride forth; this journey is yours; God is this day in your hands; get us to the French king's battle, for there lieth all the sore of the matter. I think verily by his valiantness he will not fly; I trust we shall have him by the grace of God and St. George, so he be well fought withal; and, sir, I heard you say that this day I should see you a good knight." The prince said : "Let us go forth; ye shall not see me this day return back; advance, banner, in the name of God and of St. George."

Then the prince and his company dressed them on the battle of the Duke of Athens, constable of France. There was many a man slain and cast to the earth. As the Frenchmen 
fought in companies they cried : "Mountjoy! Saint Denis!" and the Englishmen "Saint George! Guienne!" ... When the Duke of Normandy's battle saw the prince approach they thought to save themselves, more than 800 spears that struck no stroke that day. ... Then the king's battle came on the Englishmen; there was a sore fight, and many a great stroke given and received. ... On the French side King John was that day a full right good knight ; if the fourth part of his men had done their devoirs as well as he did, the journey had been his by all likelihood. Howbeit they were all slain and taken that were there, except a few that saved themselves, that were with the king. ... Thus this battle was discomfited, and it was in the fields of Maupertuis two leagues from Poitiers, on the twenty-second day of September the year of our Lord 1356 .

Exercises.-r. Analyse both descriptions of the battle and make a brief statement of the sequence of events.

2. In what respects do the accounts agree?

3. Draw a plan of the battle.

4. Compare Baker of Swinbrook's manner of narration with that of Froissart.

The sequences of events may be tabulated as follows:-

BAKER OF SWINBROOK

I. The Prince crosses the stream and takes possession of a hill.

2. The French advance, and Claremont engages the rearguard.

3. The Earl of Oxford deploys the archers on the French flank to shoot at the horses' hindquarters.

4. The French first line is defeated.

5. The Dauphin advances with the second line and is defeated.

6. The French King advances.

7. The English advance again, but make no impression on the French.

8. An English battalion takes the enemy in the rear.

9. The Prince breaks through in front.

\section{FroISSART}

I. The French cavalry advance to break the array of English archers.

2. The archers shoot at the French horse and drive them back.

3. The French immediately behind them cannot get forward, and recoil on the Duke of Normandy's foot-soldiers.

4. Some English horse and archers take the enemy on the flank.

5. The Prince in front breaks through.

6. The French King's battalion advances, and makes a brave stand, but is destroyed. 
A careful comparison of these two sequences brings out many points of interest, and gives an opportunity for discussing the great difficulty of getting an accurate account of any movements that are on a large scale.

XIV. An unparagraphed statute frequently affords a good exercise in analysis.

In the following exercise it needs close reading on the part of the pupil, if no point is to be missed.

Conditions. - The boys have read of the Black Death and the consequent scarcity of labour.

\section{Extract:-}

1350-51.

Statutes, i. $3 \mathbf{I}$.

. . Carters, ploughmen, drivers of the plough, shepherds, swineherds, and all other servants shall take liveries and wages, accustomed in the twentieth year of the present king's reign, or four years before, so that in the country where wheat was wont to be given, they shall take for the bushel ten pence, or wheat at the will of the giver, till it be otherwise ordained. And they shall be hired to serve for a whole year, or by other usual terms, and not by the day; and none shall pay in the time of haymaking but a penny the day; and a mower of meadows for the acre five pence, or by the day five pence; and reapers of corn in the first week of August two pence, and in the second, three pence, and so till the end of August, and less in the country where less was wont to be given, without meat or drink or other courtesy to be demanded, given, or taken; and all workmen shall bring openly in their hands to the merchant towns their instruments, and there shall be hired in a common place and not private.

None shall take for the threshing of a quarter of wheat or rye over two pence, and the quarter of barley, beans, peas, and oats over one penny if so much were wont to be given; and the said servants shall be sworn two times in the year to hold, and do these ordinances; and none of them shall go out of the town where he dwelleth in the winter to serve the summer, if he may serve in the same town. ... 
Carpenters, masons, and tilers, and other workmen of houses, shall not take by the day for their work, but in manner as they were wont, that is to say : A master carpenter three pence and another two pence; a master mason four pence and other masons three pence; and their servants one penny. Tilers three pence and their knaves one penny, and other coverers of fern and straw three pence and their knaves one penny. Plasterers and other workers of mudwalls, and their knaves, by the same manner, without meat or drink; that is from Easter to Michaelmas ; and from that time less, according to the rate and discretion of the justices, which shall be thereto assigned.

Exercise.-Make an analysis of the statute, and state the reason for each clause. State also of which of the clauses the bailiff of a farm would have approved.

Here the clauses work out as follows:-(I) The value of wheat fixed if " used for payment of labourers. (2) Hiring to be for the year and not for the day. (3) Scale of wages for reapers and mowers. (4) No perquisites to be given. (5) Hiring to be in public. (6) Scale of wages for threshers. (7) Migration of town labourers to the country in summer forbidden. (8) Scale of wages for carpenters, masons, and the craftsmen engaged in house-building and repairing.

The commentary asked for needs a good deal of thought, and implies a thorough understanding of the situation.

XV. Shortly after half-term certain distinct symptoms appear in most middle forms. The cleverer boys begin to leave the weaker boys behind, and in consequence the class becomes ragged. A few weak boys who have been suffering from a prevailing epidemic return to school after missing a fortnight's work, thus making matters worse. Many boys have become listless 
and bored with their work, the end of term is still too far distant for the prospect of examination to give a fictitious stimulus, and the whole class seems as heavy as lead on the master's hands. It is now with a weak teacher that signs of disorder appear, and that in general it is well to pull the class together by a stiff dose of written work.

At this juncture an exercise of the following kind is useful. The boys are asked to read a number of extracts carefully, and to write a brief connected narrative from them. The exercise here suggested might well occupy a whole period of preparation, in which the boys would make notes, and a period in class during which they would write out their narrative.

Exercise.-Give a brief account of Wyclif's views, and show to what extent his opinion of certain classes of the clergy was shared by contemporary writers.

Extracts :-

\section{A}

1377.

Translated from Latin of Walsingham, Hist. Angl. i. 324. (1394.)

About the same time there arose in the University of Oxford a Northerner called Master John Wyclif, a doctor in divinity, who publicly held in the schools and elsewhere mistaken and heretical opinions, contrary to the holding of the Catholic Church, and especially bitter against the monks and other landed churchmen. And that he might the more carefully glose his heresy and most speciously extend it, he gathered unto him workers of iniquity-to wit, friends and associates of one school abiding in Oxford and elsewhere; and these wore russet gowns, for a token of greater perfection, and walked barefooted, to spread their heresies among the people and preach them openly and even publicly in their sermons.

And among other things these were the opinions with which they were primed: that the Church of Rome is not 
the head of all the Churches, more than any other single Church, and that no greater power was granted to Peter by Christ than to any other apostle ; that the pope has no greater power in the keys of the Church than any one else in the order of the priesthood; that temporal lords may, with law and approval, deprive a bankrupt Church of its property ....; that the Gospel is a sufficient rule of life for any Christian, and that all the other rules of the Saints, to which divers men of religion conform, add no more perfection to the Gospel than doth whitewash to a wall. . . .

These and many other errors, to the great jeopardy of our Faith, were so spread by the said seducers that lords and magnates of the realm, and many of the people supported them in their preaching and favoured those who preached these errors ; doubtless chiefly for this reason, because in their teaching they gave laymen power to rob churchmen of their temporal possessions.

But when these propositions and ravings had been exposed and examined before the pope, with his own hand he condemned twenty-three of them as heretical and idle; and he sent bulls to the archbishop of Canterbury and the bishop of London that they should have the said John arrested and carefully examined on the aforesaid propositions. Whereupon the archbishop . . . in the presence of the Duke of Lancaster and Lord Henry Percy, enjoined silence on him and all others with regard to these matters. . . . And so both himself and his followers were silent for some time. But at length, by the countenance of the temporal lords, they afterwards ventured to take up again and spread among the laity the same opinions, and others much worse than those they spread before. Now on that day on which the foregoing had been transacted at London, on account of some insult uttered by the Duke of Lancaster to the bishop of London, the Londoners forthwith rose as one man, seized their arms, and purposed to put him to death. But the bishop would in no way suffer this, and had he not opposed their intent at that time, they would have burnt the Savoy, the duke's mansion, in their rage. . . . Among other insults offered to the duke, they reversed and burnt his coat of arms in the streets. 
B

Translated from Latin of Henry Knighton, ii. 151 .

(Circ. 1395.)

At that time lived Master John Wyclif, Rector of the parish of Lutterworth, in the county of Leicester, the most distinguished divine of the day. In learning he was considered second to none, in scholarship without a peer. $\mathrm{He}$ took especial pains to gain the mastery over other men's minds by the subtlety of his knowledge and the depth of his intellect, and to pervert them from their belief. It is said that he brought into the Church many opinions repudiated by orthodox divines, as will be partly shown in due course. Just as Christ had John the Baptist for his forerunner, so this man had John Ball, who prepared his ways before him in such doctrines and alarmed many by his teaching. The Gospel, which our Lord gave into the hands of the clergy and doctors of the Church, that they should minister to laymen and the weaker brethren, according to the demands of the season and the needs of individuals, was translated by this Master John Wyclif from Latin into English-speech of Angles not Angels; wherefore through him the Gospel is made common and more open to laymen and women who know how to read than it is wont to be to the clergy, till now the lettered and cultured class; and so the pearl of the Gospel is cast abroad and trampled on by swine, and thus what is wont to be dear to clergy and laity is now considered a subject of mirth to both alike, and the jewel of the clergy is turned into a laughingstock of the laity, so that what formerly had been a supreme privilege to the clergy is now for all time the common property of the laity.

\section{C}

John Wyclif (Fifty Heresies and Errors of Friars),

S.E.W. iii. 366-40I (spelling modernised). (I 384 .)

Also friars say that it is needful to leave the commandment of Christ, of giving of alms to poor feeble men, to poor crooked men, to poor blind men, and to bedridden men, and give this alms to hypocrites that feign them holy and needy when they be strong in body and have 
overmuch riches, both in great houses and precious clothes, in great feasts and many jewels and treasure; and thus they slay poor men with their false begging, since they take falsely from them their worldly goods, by which they should sustain their bodily life; and deceive rich men in their alms and maintain or comfort them to live in falseness against Jesus Christ. For since there were poor men enough to take men's alms, before friars came in, and the earth is now more barren than it was, our friars or our men had to go without this alms; but friars by subtle hypocrisy get to themselves and prevent poor men from having this alms. ...

Also friars feign them as hypocrites, to keep straightly the Gospel and poverty of Christ and His apostles; and yet they are most contrary to Christ and His apostles in hypocrisy, pride, and covetousness. For they show more holiness in bodily habit and other signs than did Christ and His apostles, and for their singular habit or holiness they presume to be even with prelates and lords, and more worthy than other clerks; and in covetousness they can never make an end, but by begging, by crying, by burying, by salaries and trentals, and by shriving, by absolutions and other false means cry ever after worldly goods, where Christ used none of all these ; and thus for this stinking covetousness they worship the field as their God. ...

Also friars be thieves, both night thieves and day thieves, entering into the Church not by the door, that is Christ. . . .

Also friars be wasters of treasure of our land by many blind and unskilful manners. For first they blind them blindly from freedom of the Gospel and then spend much gold to get them dispensation; and many times bring vain pardons and other vain privileges, and in all this the gold of our land goes out, and simony and curse and boldness in sin come again. ...

Friars also be most privy and subtle procurators of simony and foul winning and begging of benefices, of indulgences and travels, pardons and vain privileges. For men say they will get a great thing of the pope, or of cardinals in England, more cheaply than other procurators ; and they be more wily and more pleasantly can flatter the pope and his court; and 
most privily make lords to maintain the pope, in robbing our land of treasure by his pardons, privileges, and the first-fruits of benefices in our land, and dimes and subsidies to war on Christian men, for stinking worldly lordship that God has forbidden to him and all priests; and in false confession they stir lords much thereto and need to destroy the land when they maintain the pope and this false robbing.

Of these fifty heresies and errors, and many more if men will seek them well out, they may know that friars be cause, beginning and maintaining of perturbation in Christendom, and of all evils of this world, and these errors shall never be amended till friars be brought to freedom of the Gospel and clean religion of Jesus Christ.

\section{D}

William Langland, Piers Plowman, c. x. 242-258

(modernised). (I393.)

Do we see them on Sundays, the service to hear,

At matins, in the morning? Till mass begin

Or even till even-song, see we right few !

Or work they for their bread, as the law bids ?

No, but at mid-day meal-time I meet with them often

Coming in a cope as if they were clerks ;

And for the cloth that covereth them call'd is he a friar,

Washeth and wipeth and with the first sitteth.

But while he worked in the world and won his meat with truth

He sat at the side bench and second table.

Came no wine to his lips all the week long,

Nor blanket in his bed, nor white bread before him.

The cause of all this mischief cometh of many bishops

That suffer such sots, and other sins to reign.

Of a truth, an we dare say so: Simon quasi dormit;

'Twere better to watch, for thou hast great charge.

$\mathrm{E}$

Chaucer, Prol. Canterbury Tales (modernised). (1386-88.)

A monk there was, a fair one for the mastery, A rider-out, that loved venery; 
A manly man, to be an abbot able, Full many a dainty horse had he in stable; And when he rode, men might his bridle hear Jingle in a whistling wind so clear, And eke as loud as doth the chapel bell. . . . He gave not of that text a pulled hen That saith that hunters be not holy men; Nor that a monk, when he is cloisterless, Is like unto a fish that is waterless : This is to say, a monk out of his cloister. But this same text held he not worth an oyster. . . . Greyhounds he had as swift as fowl in flight; Of pricking and of hunting for the hare Was all his lust, for no cost would he spare.

I saw his sleeves trimmed at the wrist With fur, and that the finest of the land. And for to fasten his hood under his chin He had of gold there wrought a curious pin: A love-knot in the greater end there was. . . . He was a lord full fat and in good point ; His boots were supple, his horse in great estate.

Now certainly he was a fair prelate; $\mathrm{He}$ was not pale as is a pinned ghost. A fat swan loved he best of any roast.

\section{F \\ William Langland, Piers Plowman, i. 65-79 (modernised). (1 362.)}

There preached a pardoner, as though he were a priest, And brought forth a bull, with bishop's seals, And said that he himself might all absolve From fasts ill-kept and vows that they had broke. Laymen believed him well, and liked his words, And came and kneeled to kiss his bulls.

He tripped them with his letters, threw dust into their eyes, And hooked them with his parchments, rings, and brooches. Thus ye give your gold, gluttons to help, And pay it out to wantons, that love vice. 
Now were the bishop good or worth his ears, His seal should not be sent to cozen folk.

The parish priest and pardoner do share the silver

That poor parish folk should have, if 'twere not so.

G

1382. Translated from Latin of Henry Knighton, ii. 183 .

(Circ. 1395.)

There was a great increase in the adherents of this teaching, and they multiplied exceedingly as if from seed sown; and they filled the whole land, and they got to be recognised as a matter of course-just as if they dated their existence from one and the same day; and they became altogether brazen and blushed at nothing, but, as if lost to all shame, yelping both in private and public like dogs unceasingly. . . .

Thus they were popularly called Wyclif's disciples and Wycliffites or Lollards. . . . The leaders of these so-called Lollards in the early days of this cursed sect used to wear generally russet-coloured garments, as if for an outward sign of their simplicity of heart, by this means to win over cunningly the minds of those who looked upon them and make a surer approach to the task of teaching and implanting their mad doctrine. ...

[Here follows a long recital of the mode of making converts, their abuse of opponents, their fostering of domestic strife.] . . .

And so they were everywhere usually called Wyclifs disciples. And they assumed the title not unfittingly; for just as their master Wyclif was powerful and strong in discussion over opponents, and was considered no man's inferior in argument, so they, however recently they had been won over to the sect, were trained to excessive oratory and to overcome their opponents in all subtlety and wordy warfare; strong in words; great in babble ; excellent in disputations ; browbeating all in pettifogging argument. . . .

These Wycliffites used to proclaim that their sect was especially praiseworthy, and used to invite all, not only men but women to join it, urging them to reject the teaching and 
preaching of every one else, and to have nothing to do with the preaching of the mendicant friars, whom they called "false preachers"; this was their continual fervent preaching not only in private but also in public; they were always plotting against them, calling them "false friars"; they kept on crying that they themselves were the true preachers of the Gospelbecause they had translated the Gospel into English.

And so by public railing and prejudiced censure they recommended themselves to men, though not to God, and in the eyes of many damaged especially the position of the mendicant friars, for owing to the teaching and preaching of these men the friars were at that time hated by many; and the Wycliffites becoming bolder on this account strove their hardest to turn the hearts of the people still further from them and to stop them from preaching and begging, declaring excommunicate the givers as well as the receivers-maintaining that they should earn their food and clothing by the work of their hands like the apostle Paul. ... And unless God had quickly cut short the days of their pride, and dealt such affliction to their growth, I do not think that even the realm of England could suffer their subtlety and wickedness.

\section{$\mathrm{H}$}

1382.

John Wyclif (S.E.W. iii. 508) (modernised).

(1382.)

Please it to our most noble and worthy King Richard, king both of England and of France, and to the noble Duke of Lancaster and to other great men of the realm, both to seculars and men of Holy Church, that be gathered in the parliament to hear, assent, and maintain, etc.

The first article is this; that all persons of whatsoever kind of private sect or singular religion, made of sinful men, may freely, without any let or bodily pain, leave that private rule or new religion founded of sinful men, and stably hold the rule of Jesus Christ, taken and given by Christ to his apostles as far more perfect than any such new religion founded of sinful men. ...

The second point or article is this; that the men that 
unreasonably and wrongfully have damaged the king and all his council, be amended of so great error and that their error may be published to men dwelling in the realm. For the chief lordship in this land of all temporalities, both of secular men, and religious, pertaineth to the king of his general governing. For else he were not king of all England, but of a little part thereof. Therefore the men that bethink them to take away his lordship from the king, as do friars and their abettors, in this point be sharper enemies and traitors than Frenchmen and all other nations. ...

The third article is this; that both tithes and offerings be given and paid and received by that intent, to which intent or end God's law and the pope's law ordained them to be paid and received; and that they be taken away by the same intent and reason, that both God's law and the pope's law ordained that they should be withdrawn. . . . For by God and his law curates be much more bound to teach their parishioners charitably, the Gospel and God's hests both by open preaching and example of good life, for to save their souls, than their parishioners be bound to pay them tithes and offerings. ...

The fourth article is this; that Christ's teaching and beliet of the sacrament of his own body, that is plainly taught by Christ and his apostles in Gospels and epistles, may be taught openly in churches to Christian people, and the contrary teaching and false belief, brought up by cursed hypocrites and heretics and worldly priests, uncunning in God's law, cease.

\section{I}

OPINIONS WRITTEN AND PUBLISHED BY JOHN WyCLIF According to Walsingham, Hist. Angl. ii. 53 . (1394.)

No heresy or error will be able to be proved in the whole teaching of Master John Wyclif.

God must obey the devil.

The pope is more bound to the emperor than the emperor to the pope. 
There is no civil lord, no bishop, no prelate, so long as he is in a state of mortal sin.

When human laws are not founded in Holy Writ, subjects are not bound to obedience.

K

1384.

John Wyclif (S.E.W. iii. 504) (modernised).

(I 384.$)$

I have joyfully to tell to all true men the belief that I hold, and by all means to the pope; for I suppose that if my faith is rightful and given of God, the pope will gladly confirm it; and if my faith be error, the pope will wisely amend it.

I suppose over this, that the Gospel of Christ is the heart of the body of God's law ; for I believe that Jesus Christ hath given in his own person his Gospel, is very God and very man, and by this heart passes all other laws.

I suppose over this, that the pope be most obliged to the keeping of the Gospel among all men that live here; for the pope is highest vicar that Christ has here in earth. For greatness of Christ's vicar is not measured by worldly greatness but by this, that this vicar rather follows Christ by virtuous living; for thus teaches the Gospel that this is the sentence of Christ.

And of this Gospel I take as belief that Christ, what time he walked here was most poor man of all, both in spirit and in having ; for Christ says that he had not to rest his head on. And Paul says that he was made needy for our love, and more poor might no man be, neither bodily nor in spirit. And thus Christ put from him all manner of lordly worship. For the Gospel of John telleth that when they would have made Christ king, he fled and hid from them, for he would none such worldly highness.

And over this I take as belief, that no man should follow the pope, or any saint that now is in heaven, save in as much as he follows Christ. For John and James erred when they coveted worldly highness; and Peter and Paul sinned also when they denied and blasphemed in Christ ; but men should 
not follow them in this, for then they went from Jesus Christ. And this I take as wholesome counsel that the pope leave his worldly lordship to worldly lords, as Christ gave them-and move speedily all his clerks to do so. For thus did Christ, and taught thus his disciples, till the fiend had blinded this world. And it seems to some men that clerks that dwell lastingly in this error against God's law, and follow not Christ in this, be open heretics and their abettors be partners.

And if I err in this sentence, I will meekly be amended, yea, by the death, if it be skilful, for that I hope were good to me. And if I might travel in mine own person, I would with good will go to the pope. But God has constrained me to do contrarily and taught me more obedience to God than to man. And I suppose of our pope that he will not be Anti-Christ, and reverse Christ in his working, to the contrary of Christ's will ; for if he summons against reason, by him or by any of his, and pursue his unskilful summoning, he is an open AntiChrist. And merciful intent excused not Peter, that Christ called him not Satan; so blind intent and wicked counsel excuse not the pope here; but if he ask of true priests that they travel more than they may, he is not excused by reason of God that he is not Anti-Christ. For our belief teaches us that our blessed God suffers us not to be tempted more than we may; how should a man ask such service? And therefore pray we to God for our Pope Urban the Sixth, that his old holy intent be not quenched by his enemies. And Christ, that may not lie, says that the enemies of a man be specially his homely company; and this is sooth of men and fiends.

\section{L}

William Langland, Piers Plowman, A. viii. 168-187 (modernised).

(1362.)

Therefore I counsel you, ye rich men on this earth

Who trust in your treasure trentals to have (masses for the dead)

Be ye never the bolder to break the ten hests;

And in especial, ye masters and magistrates and judges, 
That have the wealth of this world, and wise men are held, To purchase you pardon and the Pope's bulls. At the dreadful day of doom, when dead men shall rise And come all before Christ, accounts to yield, How we led our life here, and his laws kept, And how we did day by day-the doom will be told. A pouchful of pardons there or provincial letters, Though we be found in fraternity of all five orders, And have indulgences double-fold,- -unless Good Deeds us help,

I set by pardons not the value of a pea or a pie-crust. Therefore I counsel all Christians to cry God mercy, And Mary his mother be our mediator with him, That God give us grace here, ere we go hence, Such works to work while we be here That after our death-day our Good Deeds rehearse At the day of doom that we did as he taught. Amen.

Of this as of all similar exercises it is impossible to say in general terms how much assistance or preliminary work for the class is needed. This must be decided by the master on the spot. With some classes it would be necessary first to read through the extracts carefully and to ask questions on them; with others half the number of extracts would be sufficient. If anything more elaborate is needed, a careful perusal of the group of extracts will show that the exercise suggested does not nearly exhaust the possible problems and questions.

For work of this kind it is essential that the apparatus, that is to say, the documents, shall be in the pupils' hands. Documents as read to a class have their value as giving atmosphere, but for the present purpose each boy must have his own book of extracts, which can be supplemented on the part of the teacher by graphed slips. The science teacher is not expected to obtain results without apparatus; each boy is provided with 
his bench, his balance, his test-tubes, and his water-tap. It would be in the highest degree unreasonable to ask the history teacher to convert his subject into an educational instrument with nothing but the text-book to fall back upon.

Here there is a difficulty to be faced. If documents are to be provided in the necessary abundance, a series of volumes is required, and many schoolmasters would shrink from asking their pupils to buy a fresh book, at the cost of a few shillings, for each short period of English history. The science laboratory indicates the solution of the problem. Boys are not expected to buy their own water-taps, Bunsen burners, and other apparatus; the school provides them, and sometimes makes a small terminal charge for their use. In the same way the source-books here referred to must be supplied as school property, and a sum of some twentyfive pounds will supply a complete laboratory for school use. Here, as with the teaching of the other English subjects, schools are only just beginning to discover that books are cheap. In how many schools are class-room libraries to be found?

In the composition of such source-books two distinct methods may be employed. In each period either a few selected episodes may be taken, and for each a number of extracts which admit of comparison and contrast may be given, or an extract may be given for each of the topics that is commonly treated of in the school history course. The solution is a compromise. For atmospheric purposes it is desirable to have illustrations of most of the events in the accepted sequence, while with problems in view a few extracts for comparison may be given. It is then left to the teacher, working on the basis of the 
source-book, to supply graphed extracts which in combination with those already before the boys lend themselves to the method advocated in this chapter. ${ }^{1}$

Note on the Methods of teaching History suggested by Rollin.

For Rollin, method consisted largely in hearing with appropriate comments a lesson that had been got up. "Young ladies study in private, and when the master waits upon them they relate to him what they have read and remarked more particularly. On this occasion the master observes whether we have made a faithful relation; if we have not omitted any essential circumstance, but have laid the most stress on those of the greatest importance; and above all, if we have taken notice of the reflections with which the work is interspersed, and which are in reality the principal fruits of history, especially with regard to youth when judgments ought to be ripened and their minds inspired with a just, a solid taste. In this view the master asks them questions; desires to know what they entertain of certain actions, whether they don't remember some that are parallel to them in another history, and what judgment they form of great men and their character. By this method the under-

1 The series of volumes from which many of the examples given here are taken is English History from Original Sources, edited by Mr. G. T. Warner and Mr. N. L. Frazer. The series is admirably arranged for school practice, and gives abundant references to the additional material on which the teacher may draw.

An interesting series is that edited by the late Professor Yorke Powell, but it is quite unsuitable to place in boys' hands, and will chiefly be of service to the teacher. Smaller compendia of sources for the teacher's use bave already been mentioned, p. 40 
standing is enlightened and improved." But he also lays great stress upon make the pupil active, and upon giving him exercises not altogether unlike some of those suggested above. The pupil is reading, say, Rollin's Ancient History. After he has read a chapter he may be asked to write out either (I) an abridgment of the chapter, or (2) an analysis of it (shorter than I), or a summary of it (shorter than 2). "Of these three kinds of extracts the first is certainly best adapted to enlighten and improve the mind," but, as it takes a long time, the analysis or the summary may often be made instead. "This exercise may be of greater advantage to boys than to the other sex, for whatsoever profession they may be designed; and will teach them to extract all the essential particulars whatever from any book. This is daily done by those who state a case before a judge, in order to give him a perfect idea of one that is crowded with numberless difficulties and evidences or proofs, the chaos of which they are obliged to clear up, without omitting anything necessary or useful." 1

1 New Thoughts Concerning Education, by Mr. Rollin. English Trans., 1735, pp. 60, 70. 


\section{CHAPTER IV}

\section{CONTEMPORARY DOCUMENTS AS ATMOSPHERE}

IN the last chapter documents have been considered solely for their value as affording material for written exercises. Even when thus used they have also their value as giving atmosphere and stimulating the imagination, and it is frequently legitimate to employ them mainly for this purpose and to make the reasoning that can be done in connection with them a secondary matter. When used thus the documents need not always be placed in the pupils' hands, though they are more effective when this can be done, and the sourcebooks to which reference has been made provide a large supply of material for illustrative purposes.

If a short document is read aloud to a class there are several rules of procedure which are well worth noting. It is of very little use to read it through once and then to expect the class to make comments upon it or even to derive an atmosphere from it; though this is a common mistake of beginners. It is difficult for an adult at the first hearing to catch the drift of any matter that is read to him, and boys certainly will not do so. The extract will need to be read through three times, say, once by the teacher, once by a pupil, and then again by the teacher, before it is worth while to comment or to 
question upon it. It is also on occasion advisable to place on the blackboard a few phrases or catchwords from it. Let the document be the following extract from a letter written by Mary Queen of Scots to Elizabeth in 1582.

Believe, madame (and the doctors whom you sent to me this last summer can have formed an opinion), that I am not likely long to be in a condition which can justify jealousy or distrust. And this notwithstanding, exact from me such assurances and just and reasonable conditions as you wish. Superior force is always on your side to make me keep them, even though for any reason whatever I should wish to break them. You have had from observation enough experience of my bare promises, sometimes even to my own damage, as I showed you on this subject two years ago. Remember, if you please, what I then wrote you, and that in no way could you so much win over my heart to yourself as by kindness, although you have confined forever my poor body to languish between four walls; those of my rank and disposition not permitting themselves to be gained over or forced by any amount of harshness.

In conclusion I have to request two things especially; the one that as I am about to leave this world I may have by me for my consolation some honourable churchman, in order that I may daily examine the road that I have to traverse and be instructed how to complete it according to my religion, in which I am firnly resolved to live and die. This is a last duty which cannot be denied to the most wretched and miserable person alive; it is a liberty which you give to all foreign ambassadors, just as all other Catholic kings allow yours the practice of their religion. And as for yourself, have I ever forced my own subjects to do anything against their religion even when I had all power and authority over them? And you cannot justly bring it to pass that I should be in this extremity deprived of such a privilege. What advantage can accrue to you from denying me this? I hope that God will forgive me if, oppressed by you in this wise, I do not cease from 
paying him that duty which in my heart will be permitted. But you will give a very ill example to other princes of Christendom of employing, towards their subjects and relatives, the same harshness which you mete out to me, a sovereign queen and your nearest relative, as I am and shall be in spite of my enenies so long as I live.

Here it will be well to place on the blackboard sentences like You have had from observation enough experience of my bare promises, sometimes even to my own damage; and As for myself have I ever forced my own subjects to do anything against their religion, even when $I$ had all power and authority over them. Comments might be made or questions asked upon either or both of these sentences, and it is useful to isolate from the other points in this way.

The constant reiteration of the same statement in a laconic chronicle is often very effective. How could the desolation of England under the Danish inroads be brought out better than by the following extract from the Anglo-Saxon Chronicle?

A. 869. This year the army again went to York, and sat there one year.

A. 870 . This year the army rode across Mercia into East Anglia, and took up their winter quarters at Thetford, and the same winter King Edmund fought against them, and the Danes got the victory and slew the King and subdued all the land. . . .

A. $87 \mathrm{r}$. This year the army came to Reading in Wessex, and three days after this two of their earls rode forth. Then Ethelwulf the ealderman met them at Englefield and there fought against them and got the victory. . . .

A. 872 . This year the army went from Reading to London and there took up their winter quarters, and there the Mercians made peace with the army.

A. 873. This year the army went into North Humbria and took up their quarters at Torksey in Lindsey. . . .

A. 874. This year the army went from Lindsey to 
Repton and there took up their winter quarters, and drove King Burhed over sea. . . .

A. 875. This year the army went from Repton. ... And the army subdued the land and oft-times spoiled the Picts and the Strathclyde Britons. . . .

A. 876. This year the army stole away to Wareham, a fortress of the West Saxons. And afterwards the King made peace with the army.

A. 877. This year the army came to Exeter from Wareham, and the fleet sailed round westwards; and then a great storm overtook them at sea and there one hundred and twenty ships were wrecked at Swanwich. :.

A. 878 . This year during midwinter, after twelfth night, the army stole away to Chippenham and overran the land of the West-Saxons and sat down there.

A. 879. This year the army went to Cirencester from Chippenham and sat there one year. . . .

A. 880. This year the army went from Cirencester to East Anglia and settled in the land and apportioned it.

From 881 to 893 the army was on the continent. Then:

A. 893. The great army ... came to land at Limnemouth with two hundred and fifty ships.

Here the expression "the army," meaning the Danes, for the English had no organised army, reiterated yearly by the chronicler in his meagre narrative, makes a more profound impression than any word painting. The extract should not be read too fast, and the "army" phrase might be blackboarded for several successive years. Or, perhaps, as a variant, a couple of pages of the Chronicle might be read to the class, and they might be asked to observe and see whether any one type of event is common to all the years.

A few short extracts graphed on one slip frequently form a good basis for a lesson, and can be used in a variety of ways. The following served to illustrate a lesson on the American War of Independence. 
London, July 7, 1773.

The great defect here is in all sorts of people a want of attention to what passes in such remote countries as America-an unwillingness to read anything about them if it appears a little lengthy, and a disposition to postpone the consideration even of the things they know they must at last consider, so that they may have time for what more immediately concerns them, and withal enjoy their amusements and be undisturbed in the universal dissipation.

(b) The interests of Newfoundland are being threatened by a scheme for the establishment of a cod and whale fishery in lake Erie and lake Ontario.

(c) There no useful profession is the subject of ridicule or contempt. - Idleness alone is a disgrace. Military rank and public employment do not prevent a person from having a calling of his own. Every one there is a tradesman, a farmer, or an artisan. Those who are less well off-the servants, labourers, and sailors, unlike men of the lower classes in Europe, are treated with a consideration they merit by the propriety of their conduct and their behaviour.

De SEGur.

The first extract gives atmosphere, as well as an opportunity of discussing the view taken of England by the colonists. The second extract introduces a question, "Does this extract from a London newspaper of the period show that the English had (I) an interest in, (2) a good knowledge of the conditions of life in America?" The third gives an opening for asking whether the first or the third extract is the more likely to be biased in its statements. Again the eternal question of evidence!

The next couple of extracts, representing a graphed slip, illustrates a lesson on Domesday Book. (A) is an 
extract from Domesday Book itself, referring to Oxford (the lesson was given in that city); (B) is the Saxon Chronicle's account of William I.'s procedure. The manner of using these needs no further comment.

(A) In the time of King Edward Oxeneford paid for toll and all other customs yearly. . . . The King has twenty wallmansions which were Earl Algars, in the time of King Edward, paying both then and now fourteen shillings less two pence. ... They are called wall-mansions because, if there is need and the King command it, they shall repair the wall. All the burgesses of Oxeneford hold in common a pasture outside the wall that brings in six shillings and eightpence.

(B) He sent his men into every shire and caused them to write down how many hundred hides of land it contained, and what lands the King possessed therein, what cattle there were in the several counties, and how much revenue he ought to receive yearly from each. So very narrowly did he cause the survey to be made, that there was not a single hide nor a rood of land, nor-it is shameful to relate that which he thought no shame to do-was there an ox, a cow, or a pig passed by, and that was not set down on the accounts, and then all these writings were brought to him.

It is not for a moment suggested that documents of this kind should be introduced into every lesson, or that there is any particular virtue in merely placing them before a class. On the contrary it should be recognised that it is illegitimate to use a document of any kind unless it is made thorough use of. With these extracts as with all other material for teaching it is necessary for the teacher to turn them over in his mind very often, and to consider how every scrap of value can be squeezed out of them. Neither should the number introduced during the term be very great. A few documents carefully studied will be impressed on the boys' minds and will serve as centres round which historical facts may be 
grouped; a large number cursorily read through will be to the pupil as a diffuse and not very well-arranged reading-book. The experienced teacher who has learned to give a long lesson on a minimum of subject matter needs no advice on this point, but the beginner, unless he is very careful, is likely to err here.

The following extract, exhaustively treated, gives ample opportunity both for revision and for introducing fresh matter.

April 7, 1416.
English Chronicle, ed. Davies, p. 42

(English modernised). (C2rca 1461-1471.)

This same year [1416] came Sigismund, the Emperor of Almaine, into England, for to speak with King Harry, to treat of certain things touching the peace of England and of France, and also for the welfare and unity of all holy Church. And the king and his lords met with him at St. Thomas Watering, without Southwark, and him received with great reverence and worship, and brought him into London, and from thence to Westminster, and there he was lodged in the palace at the king's cost, and that same time the king gave him the livery of the Garter. And when the emperor had been in this land as long as it liked him at the king's cost, he took his leave of the king; and the king brought him to Calais, and tarried there to have answer from the French party of such things as the emperor and the king had sent to them for; and at last it came and pleased them right nought; and then the emperor passed forth his way, and the king came into England again.

The passages italicised indicate the line of comment. The relations between England and France may be revised, while the occasion may be used to give a lesson upon the emperor's position as regards (I) the various European powers, (2) the Church, and to consider how far his authority depended upon tradition and how far upon military strength. There are also indications which 
should not be overlooked that the English king was gratified at having the emperor as his guest. Finally the document may be used to revise or to expand the boys' knowledge of the topography of London.

So, too, with the following document :-

1376.

Translated from Latin of Walsingham, Hist. Angl. i. 320.

(Before 1394.)

In the year of grace 1376 , at the beginning of the month of May, King Edward caused a full parliament to be holden at Westminster; and therein, after wonted custom, he did ask certain supplies from the Commons for the defence of his realm; but those of the Commons said in reply that they were exceeding weary by reason of such imposts, and maintained truly that they could no longer bear such burdens without sore hurt to themselves. For it was abundantly evident to them that the king had enough for the defence of his realm, if so be the realm had been wisely and faithfully governed; but so long as such rule were held in the realm as at this present time owing to evil men in office, it would never flourish in prosperity or wealth. And they offered to prove this beyond dispute; and if after this proof it should be found that the king were in any further need, they would help him according to their ability. Now in the conduct of the matter many facts were brought forward concerning the king's friends, and especially concerning Lord Latimer, his treasurer, who ruled the king with most evil governance. Wherefore the Duke of Lancaster, Lord Latimer, and many other high officers of the king were removed and others chosen in their places.

Here the points that may be treated are (I) the composition of Parliament; (2) the question of supply, with a revision of previous occasions (e.g. at the close of Edward I.'s first campaign in France) on which the Commons had responded liberally to the King's appeal ; (3) a consideration of the classes upon whom the burden of taxation fell most heavily; (4) the clique of persons who 
were diverting the revenue into their own purses; (5) the effective power of the Commons to remove ministers.

Although the necessity of thus getting to the bottom of a document cannot be too forcibly expressed, there is still a place in the history lesson for contemporary authorities as atmosphere and nothing more. On occasion it is right to spend half an hour in reading to a class Froissart's Chronicles or More's Utopia, or Hakluyt's Voyages, merely asking a few questions during or at the end of the reading to test and stimulate attention. In this case the boys are not expected to remember the facts and details of the narrative; the object is to interest them rather than to induce reasoning. This mode of using contemporary writers must be clearly distinguished from the method advocated in this chapter. 


\section{CHAPTER V}

\section{METHOD AND MORAL TRAINING}

THE moral value of school subjects, if this phrase means their effect upon character and upon the consequent outlook upon life, depends upon two factors-the ideas that they convey, and the mental processes through which these ideas are obtained. Subjects that give opportunity for prolonged effort are likely to cultivate the habit of persistency, and this habit acquired during school-days will tend to promote strength of will in after-life; while on the other hand a desultory trifling with interesting topics will certainly lead to listlessness and indecision. These propositions appear so full of common sense that few people would question them unless they were stated in more precise and more scientific terms. But in dealing with school history scant attention has been paid to mental processes. It has become a convention to talk of the value of the subject in forming character, and by forming character has been meant the giving of ideas about character which both provide mental furniture and working through imitation determine decision and action in periods of moral conflict. Here, however, we are confronted with the difficulty that to some boys the shady side of conduct is as likely to appeal as the sinless. In fact, if we 
suppose that from the moral standpoint the characters and actions in history are equally balanced, half being good and half being bad, the history lesson for purposes of leading to good conduct neutralises itself. Further, if we admit that the bad characters outweigh the good, then unless we suppose a natural tendency to imitate the good rather than the bad, the net effect of history will be injurious; and if this supposition is rejected as contrary to experience, it is evident that the whole question of the desirability of analysing and criticising character with junior forms calls for careful consideration.

Undoubtedly the great practical difficulty with which the teacher is here confronted is the sordid nature of most of the dramatis personae in certain periods of English history. $\mathrm{He}$ is face to face with a dilemma. If he gives these personages as examples of character to be imitated it is generally necessary to suppress facts or to amend them in a way inconsistent with historical accuracy; while if the facts of human nature are presented to children in their nakedness, they might well irreparably destroy that belief in human nature which most people recover at a certain period of life, although they may have lost it during a transition stage. Few of the history teacher's problems are more perplexing than this one. Unless he lays stress upon the ugliness and the brutality of past ages, it is difficult to bring home the fact that there has been a true progress, a real evolution in time. This is wholly obscured by the presentation to the child of the rose-coloured knights who walk sedately along their church-going paths through the pages of popular historical novels; it is obscured if we conceal the fact that kings were frequently liars and scoundrels, and their ministers self-seeking 
functionaries; it is obscured if we hide from our children, even of middle-school age, the terrible sordidness of motive that stands out so clearly in a record of private life such as the Paston Letters, and which is a fitting counterpart to the troublousness of the times; it is obscured if in treating of any period we select for friendly description only the virtuous characters, and pass over the lives of the others in silence. And yet, what may not be the cost if in adhering to historic truth we destroy the idealism of youth and prematurely lay stress on the meaner aspect of life which in any case will make itself felt only too soon!

Here the psychology of mental growth comes to our aid. The small boy is in the epic stage. Slight gradations of conduct are not for him. The good characters are good and the bad characters are bad. Rebellions, crusades, and battles give the movement, glorious victories the colour. Petty lives centred upon selfish ends, saintly lives marred by great ambitions, great ambitions vitiated by self-indulgence, desirable results gained by evil means, mixed motives in acting, lack of steadfastness in willing, all these are non-existent for this stage. A boy will read Marryat's novels without noticing the moralising, he will read Henty without remarking that much of it is as dull as his history text-book, and the more complex elements in history if placed before him are simply neglected.

Therefore, whether we wish it or not, the idealistic stage will always precede the critical, and up to a limit it is well to assist nature. Elizabeth must be good Queen Bess before the boy learns that she could swear like a fish-wife and lie like a horse-dealer; Wolsey must be the magnificent prelate and promoter of learning 
before he is displayed as having the soul of a flunkey; the utmost peccadillo allowed to a potentate must be a surfeit of lampreys, and in deference to epic justice the result must invariably be fatal. But care must be taken that this idealistic stage does not last too long, and that it is surely followed by the critical stage. If it must be remembered that idealism is needed in the early stages, it is equally necessary to remember that an excess of it even in the early stages will tend to retard mental growth. Most instructive in this connection are some answers upon historical characters and events given by Muriel Howard, ${ }^{1}$ aged fourteen, educated in a secondary school which enjoys the advantage of financial aid both from the rates and from the State, as well as the privilege of State inspection. In this case, as will be seen, the result of the history lesson has been to produce an unbounded optimism and belief in human nature.

I. Hereward the Wake was a good ruler over a country. He was ruler over English people. He was born in the year I 076 . He died in the year $138 \mathrm{r}$.

Thomas à Becket was quite a little boy when he became king. He was a good little king. He was born in the year I080, and he died in the year r 400 .

Jack Cade was a good ruler and a good man. He was born in the year I090, and he fought a great rebellion which was called Jack Cade's rebellion. He died in the year I roo after many happy years.

2. The result of the Norman Conquest was very bad. The Normans won the English at a battle near Newbury. The Battle was fought by the Normans in the year I I I 2.

3. The Magna Charta was a document which had to be signed by King John which was called the Great Charter. It was signed by King John because the Pope wanted King

1 The name is of course fictitious. 
John to sign the document. It was passed in the year 1340 . It was a great document. King John was a good king and a good man; he died in the year 1400.

The Battle of Bosworth was won by the English against the Normans in the year 1420 . It was fought on Bosworth Field. It was a great battle.

The Spanish Armada was a fleet of ships which set out for a sail on the water. The day was nice, fine, clear, and the water was calm and everything the sailors wanted.

4. The Petition of Right is a Bill passed by the King. The Bill consisted of different things, that every man and woman, boy or girl, should pay a tax of shilling raise for every boy or girl over fifteen years of age.

5. Mary Queen of Scots was a good queen and also a good woman. She was a woman who had plenty of style. She wore dresses of plenty of style. She was born in the year I 500 and she died in the year 1600 .

6. The Gunpowder Plot was started by Guy Fawkes in the year 905 on the $5^{\text {th }}$ of November. He begun by putting Gunpowder in a hole and then lit it with a match. From that day till now the $5^{\text {th }}$ of November has been called Bonfire night when people have set fireworks off on that night and fires have been going in the open air.

The effect of the history teaching that Muriel Howard has received would satisfy the most ardent advocate of direct moral instruction. Everything that has been placed before her is epic, and indeed fit for the primmest drawing-room. For her nothing that is common or mean exists. All the kings, queens, or other personages, whether they bear their own names or those of other people, whether they live for ten years or for two hundred years, are "good" men and "good" women; all the battles and documents are "great." Her optimism extends even to inanimate nature. The winds and the waves moderate their violence when Muriel Howard sets her historical sails. 
This, no doubt, is an extreme case, but it illustrates the danger of postponing the critical stage. It is during the secondary period that the boy's critical faculty is developing and must be made use of. It is by introducing criticism of a mild order that exercises of the kind already suggested can be devised. It is only if thoughtcompelling exercises can be devised that history is worth treating as a serious school subject, and, it may now be added, it is only if this formal element be there that history can be of real value as a moral training.

The value of critical exercises cannot clearly be shown without a careful consideration of the formal element in the mental complex, and a brief review of the various standpoints from which mind can be viewed and described will facilitate this None of the accepted modes of setting forth the mechanism of mental process and thus of explaining certain mental facts can be regarded as wholly satisfactory. The psychology of Aristotle was frankly what would now be called a faculty psychology. If a mental process, let us say memory, is in question, the problem is attacked by asking "to which part of the soul it belongs." The soul is viewed as composed of a number of parts working with relative independence, and one element in psychological explanation consisted in referring a particular mental fact to the operation of a certain faculty. As a convenient preliminary mode of classifying mental phenomena there is perhaps not much to be said against this attitude, and it has been really mischievous only when the explanation, a merely verbal one, has been considered final, and the door has been closed upon further research.

The method, which arose with Locke, of describing mental processes in term of ideas which initiate and 
associate with one another was an attempt to make an advance upon the older method of classification, and undoubtedly has been of use in spite of the metaphysical difficulties which it brings with it. The new way of ideas did not, indeed, entirely supplant the older method, for Kant, like Aristotle, viewed the mind as schematised and split up into a number of parts or faculties, arranged in a hierarchy and each with its own peculiar functions. As a reaction against this view we find the Herbartian psychology, which introduces the notion of ideas, though from a standpoint and with metaphysical presuppositions very different from those of Locke, and throws overboard the Kantian schematism.

In modern psychology these two standpoints are still in evidence, although they are not always clearly distinguished, and some writers of repute scarcely seem to realise when they are passing from one to the other. If mind is described as consisting of trains of ideas, if for example we explain the image of an old school-fellow which arises in our mind as due to a series of successive associations, partly of contiguity, partly of similarity, and if we further bring to our aid a certain state of feeling and a certain general aim or objective of our mental state as giving a tone to these ideas and thus finally assisting to bring into our mind the idea or meaning that we found there, or if we use the expression "psychical disposition" to describe the effect that remains behind after a state of consciousness has passed by, it is impossible not to think of the ideas and of the psychical disposition as belonging to or subsisting in a mind which is something more than they are, which possesses a greater element of permanence and independence, and which is able to observe them and to claim them as 
belonging to itself. If on the other hand we start with the conception of a central unity of mind which admits of certain phases, which may for example be discovered in a state of willing or striving, or which is conscious of itself as being pleased, or afraid, or aware, we escape, it is true, from the difficulties which ideas always bring in their train, but we are debarred from explaining or even from describing some mental processes which lend themselves to explanation in no other way save that of ideas. Frequently it is only the initial description of a mental fact that can be given indifferently in terms of either standpoint. Thus, for the idea-psychology attention takes place when a certain idea stands out clearly in or takes possession of the mind; for the ego-psychology, attention is the turning of the mind in a certain direction; but in this case it is difficult from the ego-standpoint to carry description or explanation any further.

As has been pointed out, "most psychologists adopt a middle position; they treat one side of mental life, the phenomena of sensation, perception, and imagination, and the simpler life of feeling from the first standpoint, as a series of processes; while the other portion of consciousness-thought, the higher life of emotion, and in particular the will, they regard from the second standpoint." 1 Each of these two positions, that of the egopsychology and that of the idea-psychology, leads to a characteristic educational attitude. Those who view mind as a striving, unifying entity, tend to advocate the exercising of the mind in a formal manner, to keep it in condition, as it were. Those for whom mind is a complex of meanings or ideas ridicule the notion that

1 M. W. Calkins, Der doppelte Standpunkt in der Psychologie, I 905, p. 9. 
an objectless manipulation of these ideas can be of advantage to the mind. Mind can be built up, its content can be increased and strengthened by the introduction of new ideas, but a formal training is an absurdity. A fuller description of the two positions will make the issue clearer. Let them be called Neo-Herbartianism and Neo-Kantianism.

The Neo-Herbartian educationists adopt the metaphysical position of their master, though they are always prepared to throw a portion of it overboard if its insufficiency is pointed out. For them mind consists of the ideas or meanings introduced into it. These ideas are able to adopt an attitude of attraction towards or repulsion from one another. They can collect in groups for the purpose of expelling undesirables or of summoning into consciousness ideas whose presence is felt to be a source of strength. The basis of mind is thus intellectual, it is composed of meanings, and these meanings are discrete entities. From the interplay of and struggle between these entities feeling arises, and it is therefore secondary in its nature; while from these feelings in turn will is produced, thus occupying a very subordinate position in the hierarchy. Associationist psychology is always at its worst when it treats of will and reduces it to an association complex, and Herbartianism is no exception to the rule.

It would be unfair to Herbartianism, as stated by Herbart himself, to say that for educational purposes it leads to the notion of a purely receptive mind, since for Herbart the groups of ideas that are called into existence are in their corporate nature extremely active and energetic. But the Neo-Herbartian does not escape the pitfalls of the associationist position. Mind as the 
unifying centre is left out of sight. The teacher is told that his business is to fill the mind, and unfortunately he is only too ready to accept the invitation. Applied to the teaching of history the baleful effect of this doctrine is soon apparent. History is to be " narrated," stories are to be "told," biographies are to be "placed before" the pupils, and in some mysterious way, presumably through imitation, the examples of character thus given are to mould character. Because it provides these human documents, history more than any other subject is to be regarded as character-forming; and its power in this respect is derived solely from its subject matter. There is no hint in any of the Neo-Herbartian writings that any activity peculiar to the subject matter is to be demanded from the pupil or that the virtue of the information may depend upon the manner in which it is acquired. ${ }^{1}$

Opposed to the views set forth above are those of the Neo-Kantians. Just as Herbartianism unconsciously leads its adherents to soft pedagogics, to the skilful filling of a receptive mind, so the Kantian doctrine leads

1 It may here be remarked that those writers who call themselves Herbartians, but who profess to drop Herbart's metaphysic while retaining his educational results, are lending themselves to a ncedless confusion. To say that any associationist standpoint or any demand to introduce meanings into the boy's mind is peculiarly Herbartian is to use the term to no purpose. It is impossible to discuss certain phases of educational process without in some form using the association hypothesis; it is impossible to conceive of a teacher save as a man who in some way introduces ideas. If a doctor were to proclaim himself a Harveian, we should certainly conclude that he not only agreed with Harvey's statement of the circulation of the blood, but in addition was in sympathy with some of his more characteristic views, say with his belief in final causes. Otherwise the term, as applied to him, would have no meaning. 
to the opposite notion of a rigorous formal training. Evidence of this is to be found in Kant's own lectures on Education (a subject about which he knew remarkably little), when he demands that the memory shall be exercised and that language teaching shall begin with grammar. Still more clearly is the tendency visible in the writings of a modern Kantian, Dr. Paul Natorp, from whose work Sozial Pädagogik ${ }^{1}$ we may extract a characteristic sequence of argument.

If we examine nature we find only what exists, but no hint of what ought to be, no indication of the aim we should set before us, no suggestion of the ideal. Experience, however, tells us that in addition to the knowledge of how things exist, we have also a suspicion of how they ought to exist. This knowledge we derive not from nature, but from ourselves, and not from our intellect, but from our practical knowledge, from the ideal form that is within us, from the will.

The intellect must be sharply distinguished from the will. Intellect is superior to nature. It does not depend upon facts, neither does it draw its laws from them. The formal modes of combination, the categories, are given by the intellect. The law of combination determines the fact. For the intellect nothing is determined that it has not itself determined. Intellect never reaches finality in the unconditioned. When it explains it finds an unending regress, and it appears to reach a conclusion only because it decides to go no farther. The Idea of

1 Sozial Pädagogik. Theorie der Willenserziehung auf der Grundlage der Gemeinschaft, I 899 . This admirable book, one of the most careful pieces of educational work that has recently appeared, is far too little known in England. It may confidently be commended to the reader. 
the unconditioned holds good for the understanding, but it has for it only a negative meaning, it does but indicate its limitations. Intellect does not feel the need of finality. If its logical basis, its root conceptions and formulae are clearly defined, it is content to proceed and thus to gain a fuller knowledge of its object. As a unifying and combining force the intellect deserves to be exercised for its own sake. ${ }^{1}$ It is from the will, from practical knowledge, on the other hand, that we derive our conception of what ought to be ; from it are obtained the formal laws of necessity; through it we are brought into contact with the unconditioned, with the ideal form, with the moral law. For all purposes of conduct, for the positing of ends, for the conception of ideals, we depend upon this practical knowledge, and thus the proper method of training the will is of paramount importance for the educator.

The connection between intellect-training and willtraining is a close one. "The will has its material wholly in common with the understanding; nothing that comes under the laws of will lies outside the laws given by the understanding and vice versa. From these considerations the one-sided dependence of will-culture upon intellect-culture which Herbart maintains cannot be derived. According to our view the will is in form placed over the intellect, with which it shares its content of knowledge. From the community of the subjectmatter follows the necessity of a thorough combination of intellect-training, and of will-training from the lowest

1 Natorp, op.cit. p. 273.- " The most questionable result of the Herbartian view of 'educative instruction' adopted by his modern adherents is that they have scarcely any belief in the independent value of training the intellect." 
to the highest stages of human development, and from the formal subjection of the intellect to the will it follows that the development of the understanding is a continual exercise of the will and in so far is favourable to its growth." 1

If subjects are to be arranged in order of merit for their character-forming value, this must be done in accordance with their proximity to the Idea, i.e. according to the degree of pure form to be found in them. Judged by this standard mathematics enjoys a pre-eminent position, while on the other hand history would be of little value if it only awakened sympathy with man. Unless the element of Form be there, instruction that occupies itself with men is no more educative than that which occupies itself with equations. Thus even for history and in respect of the influence that it exercises upon the will, we are brought back to the path of intellect-training. History like other subjects has an intellectual side, and it must be used to exercise the understanding. But this is not recognised. In mathematics and in mathematical science the instruction does not consist in the imparting of facts that have been discovered; yet although in history facts and their connexions have had to be discovered and established, the pupil has no suspicion of this; the accepted method for instruction in history is narration.

It is evident, therefore, that while the formal training to be derived from history is overlooked by the Herbartian, it is strongly insisted upon by the Neo-Kantian, and that the mere giving of biographies or accounts of noble actions in the hope that conduct will thereby be affected receives no support from this quarter.

$$
1 \text { op. cit. p. } 269 .
$$


There is yet another standpoint from which the necessity of a rigorous method in history teaching can be established. Once childhood is past and the boy enters upon the secondary school stage he tends to resent attempts that are made to influence his views upon morals or upon conduct. The following propositions attempt to state this tendency scientifically and to suggest a remedy.

The normal healthy adolescent mind readily adopts an attitude of contrariance when attempts are made to introduce to it ideas which embody notions of morality or of conduct. The more directly these moral ideas are introduced, the stronger tends to be the reaction against them, unless the person or the situation which introduces them is sufficiently masterful or impressive to inhibit this contrariance by introducing a strong emotional tone. Much teaching of this kind, while in a certain sense it might be effective, would not in the long run make for the moral or intellectual welfare of the pupil. This is, however, not the only method of dealing with these contrariant ideas. The attitude of reaction can be prevented from coming into existence if the ideas that convey moral notions are introduced very gradually and incidentally. This can be ensured if they are presented through the medium of problem work and investigational activity, as then very little opportunity is given for these contrariant ideas to come to the front. It is also an advantage that in these circumstances the ideas about morality will be suffused with a strong conative tone, and thus will be assisted to become moral ideas, or ideas that tend to be realised in action, feeling, or belief. ${ }^{1}$

1 For a fuller treatment of this topic see the writer's Suggestion in Education, 1907. 
If there is any validity in this train of reasoning, its application to the teaching of history demands that the formal element be used to the full, and that the merely receptive attitude on the part of the learner be given but little encouragement.

In education it is seldom wise to side with extremists, and it is not incumbent here to take up the cudgels either for the Herbartians or the Kantians. It is, however, striking that from several standpoints the moral effects of the truths contained in history appear to depend upon the method by which they are obtained. For the Neo-Kantian the will can be trained only through the vigorous working of the mind; for the believer in contrariant ideas, ideas about conduct are likely to issue in action or belief only if they are acquired through a business-like method, and it is only when history is taught in a manner which complies with these demands that it commends itself to the schoolmaster as a workable subject which lends itself to routine manipulation. When psychological analysis and the teacher's craft both demand the same method, there can be little doubt that the method is a sound one, and that therefore for the secondary stage the critical treatment of documents or other evidence, when conducted with judgment, leads to a mode of teaching history which will meet the requirements both of theory and of practice. 


\section{CHAPTER VI}

\section{ON CONCRETE ILLUSTRATION}

HitherTo stress has been laid upon the formal element in history, and this element, let it be repeated, is essential in a routine school subject; but the formalism must have suitable material to work upon, the pupil must reason about matters which are concrete to him in every sense of the word. There must be a basis of facts which interest him, of human beings with whom he is on familiar terms, of places through which he can find his way with his eyes shut, of religious movements that are as real to him as to the people who lived through them, of legislation whose force is as present to him as to those who sought to evade it, of statesmen whose wisdom he feels to have been a source of strength to national life. Unless the narrative of history lives, the formal processes might almost as well be carried out in algebra. For the newer method history is a formal study, but its formalism works in the most human subject-matter imaginable.

This looks well in print, but it is not easy to bring about in the class-room. The boyish mind loves to remain on the surface of things, if this saves trouble. It has an aggravating habit of remembering phrases, which 
mean nothing to it, and of forgetting details, which might mean a great deal. A boy will tell you with a smiling face and an apparent consciousness of merit, that Wyclif "was the morning star of the Reformation," and fail when pressed to produce any facts about either the Reformation or Wyclif. For middle forms legislation and religious changes tend to be the most stubborn of abstractions.

And yet there is nothing abstract or intangible about legislation for those who are brought into contact with it. The Company Laws are quite concrete for a boy . whose father is doing time at Portland for a breach of them; an increase in the income tax is not in the least abstract to the boy who is told that for him and for his brothers it means a fortnight less at the sea-side. For the boy as for the old lady whose idea of history is the chronique scandaleuse of a French court, the concrete is the small human detail, and if we can show in this detail the effect that legislation had upon the lives of human beings, its abstract appearance vanishes at once.

"The Statute of Mortmain checked the giving of land to corporations which were unable to perform feudal service." Of all the dry portions of English history the legal activity of Edward I. can be the most arid; it is a veritable Sahara of legislation. Let us apply our remedy to it.

To introduce the personal element a little fiction is useful. We introduce two barons, each living on his own estate. Let them be called baron A and baron B. Let the estates be drawn upon the blackboard, and let each baron be domiciled in his stronghold. 

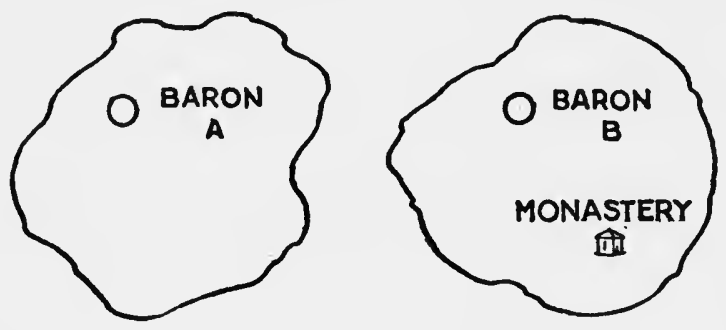

On what tenure did they hold their estates? What duties or payments to the over-lord did the feudal system bring with it?

We revise some of the feudal incidents that suit our purpose: (1) Wardship; (2) Fine on the marriage of heiresses; (3) Intestacy; (4) Escheat for treason; and make it clear that it was from these and similar sources that the king's purse was filled, and that in this respect some barons must have been worth more to him than others.

Wenow proceed to give a description of our two friends.

Baron $A$ is some thirty-eight years old; he married young, and his two sons are of age; his two daughters have been married for some years; he is businesslike, and has made all arrangements for the disposition of his property; he is extremely loyal. What are the king's chances of getting from this baron any of the fines mentioned above? Extremely small.

Now consider baron $\mathrm{B}$ : he is forty-eight years old, a considerable age for this period, and is in poor health; he married late, and his eldest son is only fifteen years of 
age and of feeble constitution; he is unbusinesslike, and has probably not made the necessary legal arrangements about his property; he has three unmarried daughters who may become heiresses; he is suspected of treasonable designs.

What are the king's chances of getting fines from him? Very considerable. Such a baron must have been a godsend to an extravagant monarch. Which of these barons is of greater value to his lord in this respect? Obviously baron $\mathrm{B}$.

Baron B, as narrated, is in poor health. $\mathrm{He}$ was always of a religious disposition, and as he grows feebler he sees a good deal of the neighbouring abbot. Finally, regardless of the interests of his children, he makes over the whole of his property to the monastery on his estate. What will the king get from the monastery on the counts mentioned above? Nothing whatever. It must be made clear to the class that there will be no orphan sons, no heiresses, no intestacy, for a corporation cannot die, no escheat for treason, for monks do not rebel.

If, then, many barons imitate $\mathrm{B}$, what is the result to the king? Poverty ; no pocket-money. How can he prevent this? Evidently by forbidding the alienation of lands to corporations of this kind.

The statement of the Statute of Mortmain can now follow. Its abstract nature has vanished.

For small boys the Constitutions of Clarendon are equally unpromising. Here are some of them :-

I. Bishops and abbots to be elected before the king's officer with the king's consent.

2. Bishops to do homage to the king for their lands.

3. Ecclesiastics not to leave the land without the king's consent. 
4. No tenant in chief to be excommunicated without the king's consent.

5. The king's court to decide on the court to try cases between laymen and clerics.

6. Clerks after conviction in ecclesiastical courts to be handed over to the lay courts.

7. No appeal to be carried beyond the king's court (i.e. to Rome) without the king's consent.

8. Villeins' sons not to be ordained without their lord's consent.

Again the personal element will give meaning to these clauses. Becket's view of them is, of course, a text-book matter and, as stated in the text-book, is abstract; but if his life is given with considerable detail this objection vanishes. A little imagination will help. A description of the feelings of the inferior clerk who has committed a misdemeanour, and who finds to his horror that ultimately he will be dealt with by an uncompromising bench of lay judges ; or of the villein's rage when he finds that his ambition to exchange the rigour of a villein's life for the comparative ease of a clerk's is frustrated by his lord, who wishes to retain a sufficient supply of labour on his estate. Enactments appear far more concrete if the way is paved for them, so that when they actually arrive they appear to the pupils to be overdue. Thus Magna Charta can be prepared for lessons in advance by keeping a black book of the grievances endured by barons, by merchants, and by villeins and the defenceless generally. In this book can be entered instances of wrongs received as they occur in the historical narrative. By 1215 the number and the gravity of these will constitute a scandal, and the action of the barons in demanding a definition of feudal dues, the proper administration of 
justice, no imprisonment without trial, freedom of trade for merchants, and a reform of the forest laws will appear reasonable and indeed necessary.

Religious changes and religious legislation present a greater difficulty. For a healthy boy the intensity of pure religious feeling is not easy to understand, and the religious feeling that arises out of nothing deeper than tradition or convention, but which is such a powerful motive when combined with party or class spirit, is wholly unintelligible to him. And yet in some periods of history the whole political situation depends upon the religious question, and in the text-book is frequently introduced by it. Here is a text-book sequence of the events at the beginning of Elizabeth's reign.

Elizabeth's succession; supported by Philip; her religious views; the Church of England; attitude of the people towards Elizabeth's religious reforms; Elizabeth's foreign policy; her attitude towards the Huguenots and Catholics.

Following this sequence the first lesson or lessons must be on Elizabeth's religious views. The formal treatment of the matter is easy enough. If we indicate the three parties in England-the Roman Catholics, the Moderates, and the Puritans-the boy may be led for himself to see that if she joined the Puritans she would alienate the Moderates and the Catholics, that if she joined the Catholics she would dissatisfy the Moderates and the Puritans and at the same time confess herself illegitimate, and that therefore her only plan was to steer a middle course between the two extremes and to commit herself to neither side. Here the class may be induced to draw an inference, and working on these lines, if the mutual relations of England, Scotland, France, 
and Spain be given, and a blackboard map of Europe, in which the religion of each country is indicated by a characteristic shading is provided, may be exercised in considering how this middle position in religion would affect her relations with foreign countries. Undoubtedly boys can be made to reason thus; but it is all in the air. The kings of Spain and of France, and the countries that they represent are little more than symbols. Guided by a strong teacher the class will juggle with these symbols.

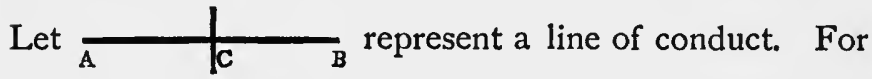
political reasons it is unwise for Elizabeth to take up her position either at $A$ or at $B$; she therefore bisects the line and chooses C. This is barely a parody of the text-book.

In a day-school a little more reality can be introduced by starting with something familiar to the boys. If it be asked how many of them are acquainted with the High and with the Evangelical churches in the town, how many know the Catholic and the Nonconformist chapels, the teacher will be overwhelmed by a list of places of worship, the greater part of which will often be new to him. The boys can then be made to realise the difference of ceremonial to be found in the various churches, and from this external standpoint an opportunity occurs for a little schematic work on the blackboard, e.g.

In Elizabeth's time we have

The Catholics. The Moderates. The Puritans. corresponding now to

The Catholics. The High Church. The Low Church and Nonconformists.

and it may be brought home to the class that the extreme High Church party does very fairly correspond to the 
Moderate party of that date and represents the compromise that Elizabeth most fancied. This linking of the past with the present may be emphasised by reading to the boys some of the thirty-nine Articles, not with the least intention of explaining them, but to show that they are really there in a book which the boys handle every Sunday, and that a portion of their weekly experience dates from this period.

Still, after our best efforts, it must sorrowfully be confessed that the class does not as a rule display enthusiasm about the acts of Supremacy and Uniformity. They will learn their contents dutifully, but the whole business means very little to them. The fact is that we have committed a fatal error in following the sequence of the text-book in our presentation. If we link this legislation on to the concrete activities of the time we shall make our task easier.

Consider the following document (an extract from a Statute of 1562 ) as a starting-point for the religious element.

XIV.-And for increase of provision of fish by the more usual and common eating thereof, be it further enacted by the authority aforesaid, That from the feast of St. Michael the archangel in the year of our Lord one thousand five hundred sixty-four, every Wednesday in every week throughout the whole year, which, heretofore, hath not by the laws or customs of this realm been used and observed as a fish-day, and which shall not happen to fall in Christmas week or Easter week, shall be hereafter observed and kept, as the Saturdays in every week be or ought to be : (2) and that no manner of person shall eat any flesh on the same day, otherwise than ought to be upon the common Saturday.

XXXIX.-And because no manner of person shall misjudge of the intent of this estatute, limiting orders to eat fish, and to forbear eating of flesh, but that the same is purposely 
intended and meant politically for the increase of fishermen and mariners, and repairing of port-towns and navigation, and not for any superstition to be maintained in the choice of meats.

XL.-Be it enacted, That whosoever shall by preaching, teaching, writing or open speech notify, that any eating of fish, or forbearing of flesh, mentioned in this statute, is of any necessity for the saving of the soul of man, or that it is the service of God, otherwise than as other politick laws are and be; that then such persons shall be punished as spreaders of false news are and ought to be.

The seafaring life of the time makes a strong appeal to a boy's interests, and here we find the religious question arising out of it in the shape of an injunction to eat fish on certain days in order that a breed of sailors may be preserved. Why is all religious intent so violently disclaimed in section 40 ? Here is an occasion for revising the religious disputes, and for introducing the new legislation. Nor is this the only opportunity for doing so; there are many connexions with the navy. Drake's father was a chaplain in the Royal Navy in the reign of Edward VI.; and the sailors in the south of England seem in general to have been Protestants, probably because their opponents the Spaniards were on the Catholic side. It was from the captain of a Huguenot privateer in the Spanish main that Drake learned of the massacre of St. Bartholomew, and later on his adventures give the teacher an opening for revising the Act of Uniformity. Drake has returned from Nombre de Dios, has come to anchor off Plymouth, and sends a boy on shore to announce his arrival. It happens to be Sunday morning and the boy finds the worthy inhabitants of Plymouth in church. He sings out to them that Drake is back; upon which they promptly 
leave the parson to preach to empty benches and rush down to the shore to catch the first sight of the ship.

No matter how lamely he may tell the story of Drake's exploits, and of this dramatic home-coming, the teacher will have no difficulty in riveting the whole attention of his class, and here he can switch them off on to the Act of Uniformity. What was the interior of the church like? Was there a crucifix? Was Mass being celebrated? Were vestments worn? Were all the citizens there? What was the penalty if they absented themselves? The interest engendered by the "Sea-Dog" narrative will be transferred to the greyer matter of religion, and although it will evaporate by degrees, some minutes may elapse before the class realise that a march has been stolen upon them, and that they are paying whole-hearted attention to a subject hitherto regarded with suspicion.

It is upon the skilful combination of small personal detail with the sterner facts and wider generalisations of history that the successful handling of this subject often depends. These small details can be obtained only from larger books. Such a work as Corbett's Drake and the Tudor Navy will furnish abundant material for the lastmentioned topic, and the numerous monographs on leading historical characters provide an ample storehouse to draw from. The smaller schematic treatises do not provide the requisite material, since they are unable to devote sufficient space to the human side of historical characters. Their actors are but lay figures whose names stand for political abstractions. The ordinary voter at the polling-booth frequently cares more for the human side of the candidate than for his political views, and for the boy the 
historical character must first be a human being before his moves in the game of statecraft will excite interest. It is commonplace to say that biography is an open gateway to history, but it is perhaps not always realised that unless the biography is made, in parts at any rate, extremely personal, it is for the boy not much less abstract than the ordinary historical narrative. ${ }^{1}$

Of especial value in this connexion are any facts that we can ascertain about the childhood and youth of historical characters, as these are nearer to our pupils' sympathies. In some cases a little imagination is necessary. It is easy to imagine the political echoes that found their way into the nursery of Edward III. His attendants with long faces must have talked to one another of the crushing defeat at Bannockburn, and have whispered that some one's incompetence was to blame. As he grew into boyhood the young prince must have realised that his father was despised by the more sturdy of his subjects, that he had a knack of choosing the wrong friends and that he was treated with scant regard by his wife; and he must early have made up his mind that, at any cost, when the time came he would establish his authority in his country and make himself master in his own house. In each fresh chapter the text-books bring to the front fresh personages who appear on the scene as having success or notoriety. It is the genesis of this success that illuminates the situation, and it is this that we must try to give. Boys will be far more interested in the relations between

1 An excellent series of biographies for school use is to be found in the series History in Biography, edited by Miss Beatrice Lees. The volumes are of unequal merit, but they are sympathetically written and abound in interesting detail. 
Queen Mary and Elizabeth if they know something of their childhood; if they realise their relative ages, on what occasions they were together in early life, where they lived, and what they were doing during the later years of Henry VIII. and the reign of Edward VI.

Henry VIII.'s wives, if nothing more than a series of names, too often appear to boys as the nearest approach to an after-dinner jest that the text-book allows itself. Yet once detail is given they are interesting personalities. There is real pathos in the life of Catherine of Aragon and in her treatment by her husband, and unless the proper facts as to the characters and family connexions of Anne Boleyn and Jane Seymour are known, it is difficult to appreciate the varying religious and political outlooks of Mary, Elizabeth, and Edward VI. In many cases it is through the personalities of great actors other than the kings (who often are only fit to appear as incidents in the lives of their own subjects) that we reach the inner history of movements. It is impossible to understand the early Church without some knowledge of the lives of Dunstan, Anselm, Becket, and Grossetête ; or the working of Feudalism without an acquaintanceship with men like Robert of Bellême, Hubert Walter, Hubert de Burgh, and Simon de Montfort. The ladies too have been unduly neglected. Sometimes a longlived and sturdy queen will give unity and connexion to a series of rapidly shifting scenes. Margaret of Anjou is a good example. During a period when political parties were being formed and reformed with startling rapidity, and leaders were suffering defeat and death or retiring into obscurity with the most thoughtless indifference to the feelings of the twentieth-century boy who was doomed to learn the list of their victories 
and reverses, the figure of Margaret stands out like a landmark. A line of time placed on the blackboard and entered in the boys' notebooks will bring this home and will show how she was actively engaged through the whole of this dreary period, and outlived most of her friends and foes.

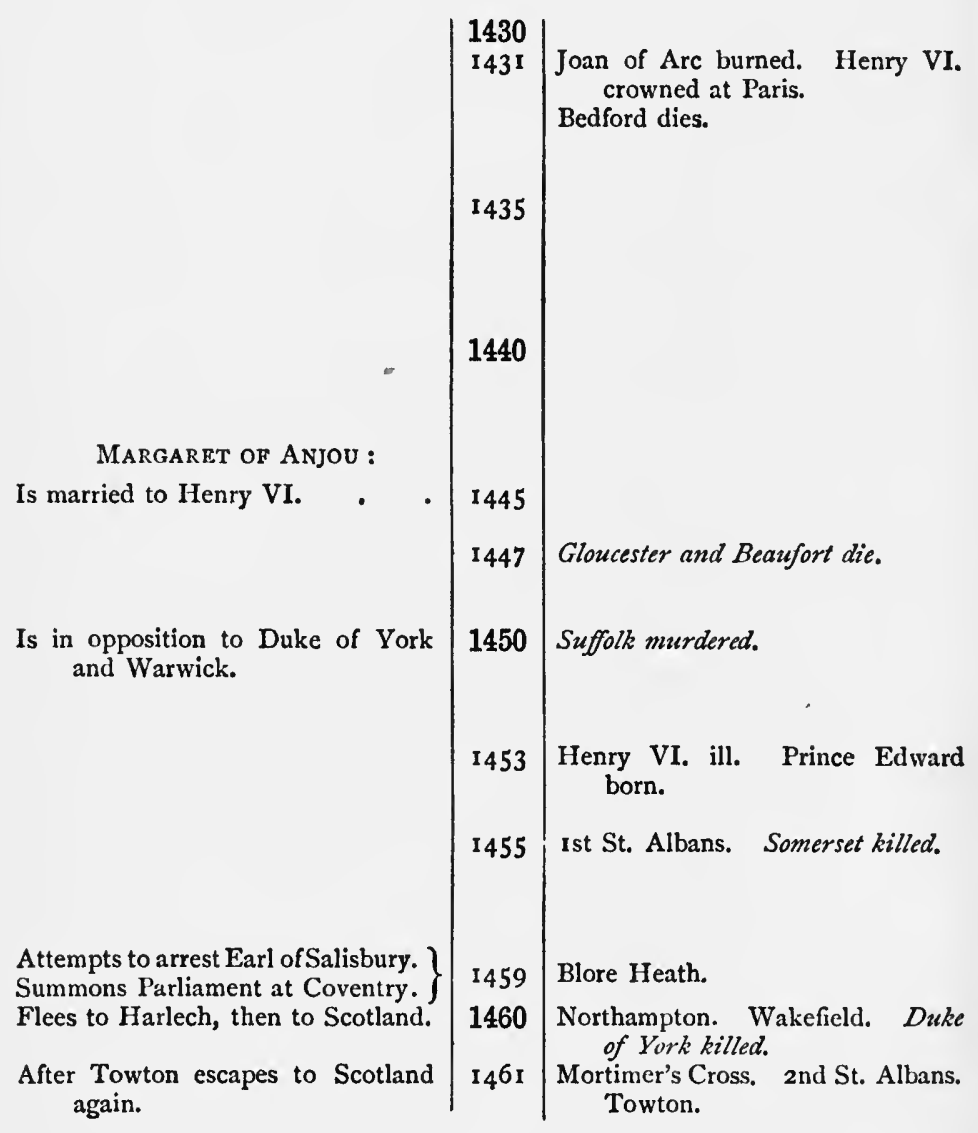


Goes to Louis XI. for help, and returns to Scotland with troops.

After Hexham is abroad for 7 years in poverty.

Is reconciled to Warwick paraded in Edward's triumph. $\left|\begin{array}{l}1462 \\ I 464 \\ 1465\end{array}\right|$

Edward IV. marries El. Woodville. Hexham.

Edward captures Henry VI.

Dies in France in poverty . . 1482

Clarence and Warwick invade Eng. land. Edward IV. to Flanders. Edward defeats and kills Warwick at Barnet.

Margaret defeated at Tewkesbury. Henry VI. dies in Tower.

Clarence executed. 1485 Bosworth.

Almost all the incidents in Margaret's career that are entered on this table are of an adventurous kind, and her courage and enterprise never fail to prove attractive.

Less exciting but of greater importance to an understanding of his period is the life of Burleigh. A section of the boy's notebook may well be reserved for him. It is suggested that the left-hand page may be occupied by a line of time, and that the opposite page may be filled with quotations, references, and expansions of details, and further facts about his life. The following extract taken from such a notebook will make this clear :- 
1520 Burleigh born. Ficld of Cloth of Gold.

Father a substantial squire and favourite at Court : gets money from monastery funds.

At School at Grantham.

At St. John's College, Cambridge. Hired bell-ringers to call him at four in morning. Greek scholar. Friend of Cheke, afterwards tutor to Edward VI.

At Gray's Inn.

Disputes with chaplains at Court and wins Henry's favour.

At Pinkie.

Secretary to Somerset.

Cecil keeps very quiet. When Somerset goes to Tower all his friends imprisoned except Cecil.

Now living at Wimbledon and at Cannon Row, Westminster. Secretary of State. Carries out wishes of Council without imposing his own views.

"The realm cannot be rich whose coin is base"; but he puts through the debasement of the coinage. 42 Articles referred by Cranmer to Cecil.

Is "ill" when Northumberland wishes to exclude Mary from succession; but he had to sign document at last. Afterwards excuses himself to Mary.

In Elizabeth's confidence and manages her business affairs. 
Hard worker except at meals, when he chatted wittily, but never of business. Played no games; not sportsman.

Maxims for his son: "Beware of being surety for thy best friends: he that payeth another man's debts seeketh his own decay." "Be sure to keep some great man thy friend, but trouble him not with trifles; compliment him often with many yet small gifts." "Towards thy superiors be humble yet generous; with thine equals familiar yet respectful ; towards thine inferiors show much humanity and some familiarity, as to bow the body, stretch forth the hand, and to uncover the head."

1552. Cecil's note as to question "Whether the King's Majesty shall enter into the aid of the Emperor."

\section{Answer: He shall.}

1. The King is bound by the treaty, and if he will be helped by the treaty he must do his part.

2. If he do not aid, the Emperor is like to ruin, and consequently the House of Burgundy come to the French possession, which is perilous to England, and herein the greatness of the French King is dreadful.

3. The French King brings the Turk into Christendom.

4. If the Emperor is forced to come to terms with the French King the danger is greater. (a) the Emperor's offence for lack of aid ; $(b)$ the French King's enterprises towards us.

5. Merchants be so evil used that some remedy must be sought. Answer: He shall not.

I. The aid is too expensive.

2. If the Emperor should die we should be alone in the war.

3. The German Protestants may be offended.

4. Our friendship with France may improve.

\section{A middle way.}

So to help the Emperor that we may also join with other Christian Princes and conspire against the French King as a common enemy to Christendom.

Reason for this.

The cause is common, and therefore there will be more parties to it.

Reason against.

The treaty must be with so many parties that it can be neither speedily nor secretly concluded.

(To this the King adds in his boyish hand.)

Conclusion.- The treaty to be made with the Emperor and by the Emperor's means with other princes. ${ }^{1}$

Q Quoted from the memorandum in Sir William Cecil's bandwriting by Martin A. S. Hume. The Great Lord Burleigh, 1898, p. 33 . 
Set out on a moderate scale, the complete line of time for Burleigh, with fragments of detail on the opposite page, will occupy some six or eight sides of the boy's notebook. Some judgment is, of course, required in deciding whether certain events shall be entered under this heading or shall be placed in a more general sequence. The value of the detail brought in under the heading of "Cecil's note" needs no comment. It gives an opportunity from the personal standpoint of going into the political problems of the period, and also affords a good illustration of Burleigh's laborious habit of considering every side of a question. For working purposes one instance of this is enough. Some teachers might prefer to select their instance a few years later on, in connexion with a more important problem; but perhaps it is well to indicate Burleigh's character early in the proceedings.

With small boys it is often desirable to ask them to compare in their minds two personalities to whom they are introduced. For instance, in the reign of Elizabeth, as soon as Mary Queen of Scots comes on the stage as an important actor the class may be told that at the end of a few lessons they will be asked to write a short essay on the respective characters of the Queens. This procedure gives them a private standpoint from which to observe the facts placed before them, and such a standpoint is the surest aid to attention. Many adults fall asleep during a dull sermon, but there are few who could not keep awake and attend if they were asked to make a private report upon the ability or the reverse of the preacher; if, in fact, they were given some reason for attending. In the early stages it is not of much use to give this injunction in general terms without first 
explaining that a general view of character can be attained only by observing the actions of any one in detail. This can be brought home by a little personal allusion. "Jones, if you wish to make up your mind about Brown's character, how do you begin?" Make it clear that the only method is to watch Brown on various occasions and notice if he speaks the truth, if he cribs, if he is punctual, if he is hard-working, if he is generous, and so on, and by a generalisation from these details to reach some view as to his character. The application to the personages in the lesson can now be made. What are you going to look out for in Elizabeth and Mary? Instances where they tell the truth or lie, where they are merciful or the reverse, where they are stingy or extravagant, where they excite enthusiasm in their followers or fail to do so. The danger of premature generalisation must also be guarded against. When the Lords of Congregation rebelled, Elizabeth helped them, only to vow, after they had been beaten, that she did not. "Brown, what does this tell us about Elizabeth's character?" Brown, with great promptness, "She was a liar, sir." "But, Brown, yesterday you told me that you were not eating in class when you obviously were. Am I on that account to take it for granted that you never tell the truth?" Consternation and collapse of Brown, and occasion for a short homily upon the iniquity of drawing conclusions too soon.

It is a common maxim that boys should never be given the characters of historical personages, but should work them out for themselves from the facts of conduct. Like so many other maxims of teaching, this only indicates a mode of procedure which is useful and may be employed when suitable. In certain cases the 
character of a prominent actor, e.g. of Charles I., may be the key to the whole situation, and unless some clue is given to it at the beginning, or a very premature generalisation is permitted and afterwards amplified, the inwardness and the connexion of events will be but poorly understood.

Unless care be taken, no portion of the text-book symbolism tends to be more abstract than that of chronology. It must never be forgotten that the boy's sense of time is very weak. That of the adult has been educated by the experience of events covering a stretch of thirty years, while the boy's life of memory averages only ten. If his power of casting back is weak, his power of casting forward is even weaker. An imposition that has to be shown up in a few days is dismissed lightly from the mind in the vague hope that something may turn up before that remote period arrives. In the same spirit a man might readily promise to meet a liability in ten years' time.

The relation of the history teacher to chronology is twofold: it is for him both a subject to teach and an instrument to train with. Unless the pupil's time-sense has been educated, the facts of history, which cannot be divorced from their chronological connexion, will be unintelligible to him, and it is the function of chronology to give this education. Other subjects in the curriculum, music for instance, are of use in this connexion, but the chronological element in history is the most important.

Two not uncommon practices on the part of history teachers militate against the growth of the time-sense. Boys are often rapidly transferred from one isolated period to another. In one term or year they are working at a period of Roman History, in the next they are 
introduced to the Reformation in England, and this may be followed by a dose of Feudalism under the Norman kings. Or again, the boy may complete a period of Roman History, and then for purposes of an external examination suddenly be transferred to a period of English History, while in his mind the intervening stretch of years is left a blank. Such a treatment of the sequence of events is more likely to disorganise what time-sense may be there than to develop it. This error of arrangement is, however, easily recognised, and the remedy is easy to find.

More serious because more elusive is the habit of treating the facts of history as conveying ethical maxims, and in this way of confounding the present and the past : of presenting together the characters of Cincinnatus, Sir Thomas More, and General Gordon as examples of conduct good for all time. In this way the idea of change in time is weakened, the difference between the then and the now is concealed, and the erroneous notion is fostered that there is no true history, no development. Historical novels can be great offenders in this respect. Their errors of fact may be forgiven them-indeed the correcting of these is a good exercise-but the false atmosphere that surrounds the events, equally untrue for all periods and equally serviceable for all, since it is not aggressively modern, does not serve to impress deeply upon the reader the great gulf that separates age from age.

It is easy to avoid these errors of treatment, and a more positive method is within reach. Chronology can be made concrete, the flow of time can be stated in terms of space, and through the device of the line of time the chief events of 10,100 , or 1000 years can be 
depicted, and their relative position made clear at a glance. This device is too well known to need much description in detail, but it is often neglected, and a few words may be said as to its value.

It is as easy o over-use the blackboard as to neglect it ; indeed no teaching is worse than that which plasters the blackboard with names and dates which are in the text-book and can be consulted there, or if they are not, can be dictated to the boys for insertion in their notebooks. For much writing on the blackboard takes a long time and prevents the teacher from paying full attention to his class : it should therefore be restricted to essentials. In every lesson, however, that is concerned with a series of events a few names and catchwords on the blackboard are necessary, and it is frequently advisable to arrange these in a line of time. To facilitate this there should be on the left-hand edge of the blackboard a line in white paint divided at intervals of six inches. These divisions may represent I year, Io years, or Ioo years according to the scale of events treated of, and it is as easy to jot down a short list of events in connexion with this line as to do so independently of it. In a lesson on the Parliaments of Charles I. the catchwords on the blackboard might be as follows :-

I625. Ist Parliament. Insufficient grants for war.

1626. 2nd Parliament. Impeachment of Buckingham.

I628. 3 rd Parliament. Petition of Right. Assassination of Buckingham.

r629. Protests against illegal taxation. Dissolution of Parliament.

1640. Short Parliament (4th). Long Parliament (5th).

I64I. Triennial Act.

These catchwords, as they stand, would be of use in 


\section{ON CONCRETE ILLUSTRATION I4I}

aiding the boy's attention, but it takes no longer to write them as follows, and the arrangement brings out the meaning of the whole situation far better :-

1625 Charles I. Ist Parliament. Insufficient grants for war.

I626 2nd Parliament. Impeachment of Buckingham.

Protests against illegal taxation. Dissolution of Parliament.

1640 Short Parliament (4th). Long Parliament (5th).

I64I Triennial Act.

Or again, consider the career of Mary Queen of Scots when set out as follows :-

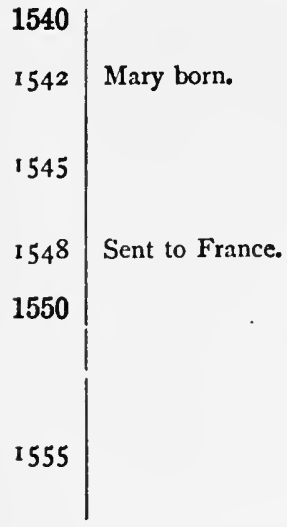




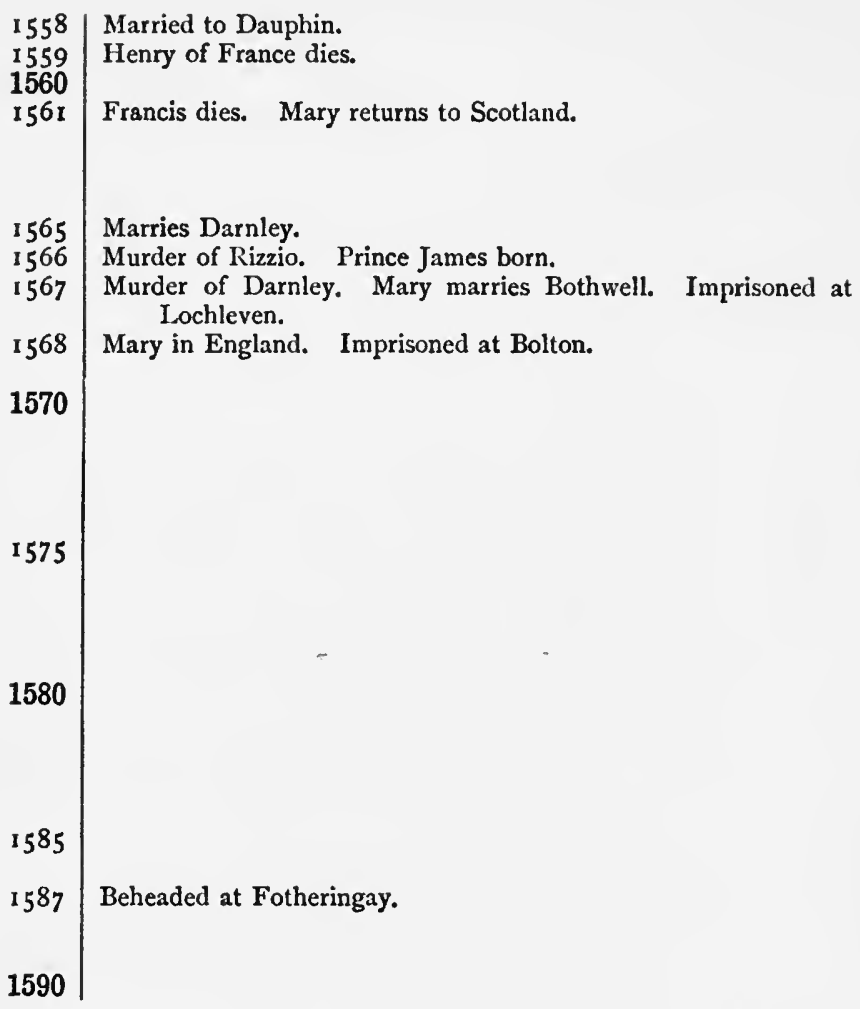

If the events are spaced out in this manner it is brought home to the pupil that Mary was in France during all her early years, that she was Queen of France for a very short time, that her residence in Scotland as Queen was short, although as far as action and excitement went extremely full, while for nearly twenty years, almost half her life, she was in England, either in prison or under close surveillance. A mere knowledge of the dates does not give to the full the sense of proportion or of relative duration. Indeed an extensive knowledge of 
dates is neither necessary nor desirable; with a few landmarks the boy must of course be familiar, but during the term comparatively little stress should be laid upon memory work of this kind. Any teacher of experience knows that there are boys who can rattle off dates glibly, but who, if asked, take time to consider whether a certain event took place before or after another. Memorising of dates may therefore be postponed until immediately before the terminal or yearly examination.

A very little practice will get the teacher into the habit of frequently using such lines of time when at work. In many cases they should be entered in the boys' notebooks, and often it is well that they should be taken down as they are put upon the blackboard. If a rule be made that boys are to take down everything of a formal nature that is placed on the blackboard, the teacher will be stimulated to prepare his blackboard work with some care, and will avoid using it to no purpose; but this is perhaps a counsel of perfection. It is often of the greatest use to have permanently on the class-room wall a line of time showing the main events in the whole period taken during the term. This can be filled in as the term proceeds, and lends itself to rapid recapitulation; it can be placed upon a strip of blackboard cloth $8 \mathrm{ft}$. long, and the use of different coloured chalks to denote different types of events increases both its clearness and its suggestiveness.

Genealogies, or a complicated group of relationships, are to the average boy quite as abstract as chronology; and the genealogical table of convention as often used can be very little illuminating. The following table, for example, is not calculated to make a boy's pulse quicken with the romance of kingship and of royal vicissitudes :- 


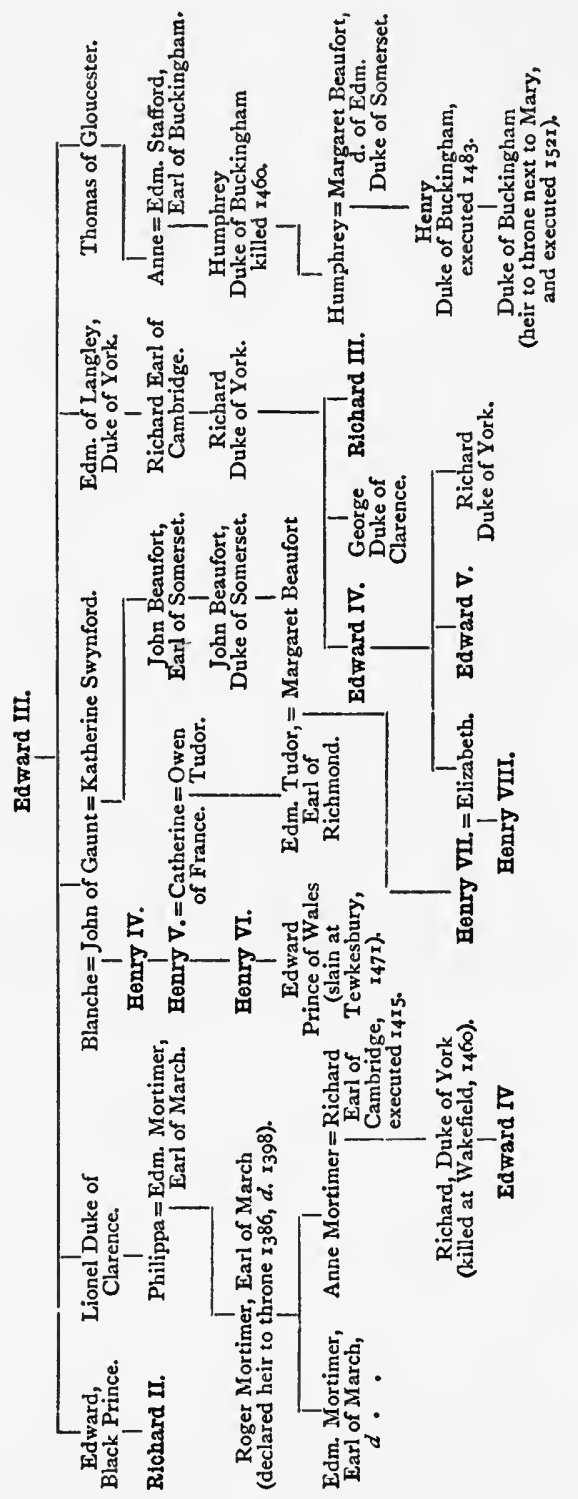


In no period of English History is it more necessary to understand the relationships of the various characters, and in none is it harder to do so. The death struggle of the feudal system in England has in it so many elements of real importance, that in spite of its petty complexity it is impossible to suggest its omission from the school course. Indeed if there were no other reason it would be a sufficient warrant for its retention that many of Shakespeare's Historical Plays treat of this period. Yet, unless the genealogies are understood, the sequence of events means little, while a thorough grip of the table given above is not easy for the average boy to attain without a great expenditure of time and effort on the part of both pupil and master.

Some general remarks upon the treatment of such schemes are not out of place. Genealogical tables should be in the text-book, and indeed are to be found in all good ones; but this is not enough. They are there for revision purposes only, and their first presentation to the boy should be on a larger scale. A convenient method is to write the genealogy clearly on a blackboard sheet and to let it hang in view of the class during every lesson. No pressure should be put upon the pupils to commit it to memory until the examination is approaching ; even the attempt to revise the important relationships "without book" at the beginning of the hour takes a long time if the weaker boys are attended to, and this time can be more profitably spent. With the table before their eyes it is not difficult to revise briefly. Yet this apparently mechanical process demands that the boys shall understand how to read a genealogy, and the writer has on several occasions been surprised to find that boys even of fourteen make ludicrous mistakes and 
find a great difficulty in describing relationships as thus set forth. Assuming that some preliminary drill has been given, the lesson can begin by a few questions on relationships. What relation was Henry IV. to the Black Prince? Was Henry V. to the Earl of Somerset, to the Duke of Somerset? Was Richard Duke of York to Henry VI.? Was Edmund Mortimer to Richard Duke of York? Was Catherine of France to Henry V.'s brothers? These questions appear trivial; a short experience shows that they are not unnecessary. When the table is there, and is understood, even a stupid boy should be able to answer questions as to the relative validity of the claims to the throne of Edward IV. and of Henry VI., or of Richard III. and Henry VII., and will see at a glance that the birth of a son to Henry VI. made civil war almost inevitable. If the table is not in evidence, the chances in favour of wrong answers are great, and valuable time is wasted.

The genealogy given above needs to be supplemented by others on a larger scale such as the following :- 
ON CONCRETE ILLUSTRATION I47

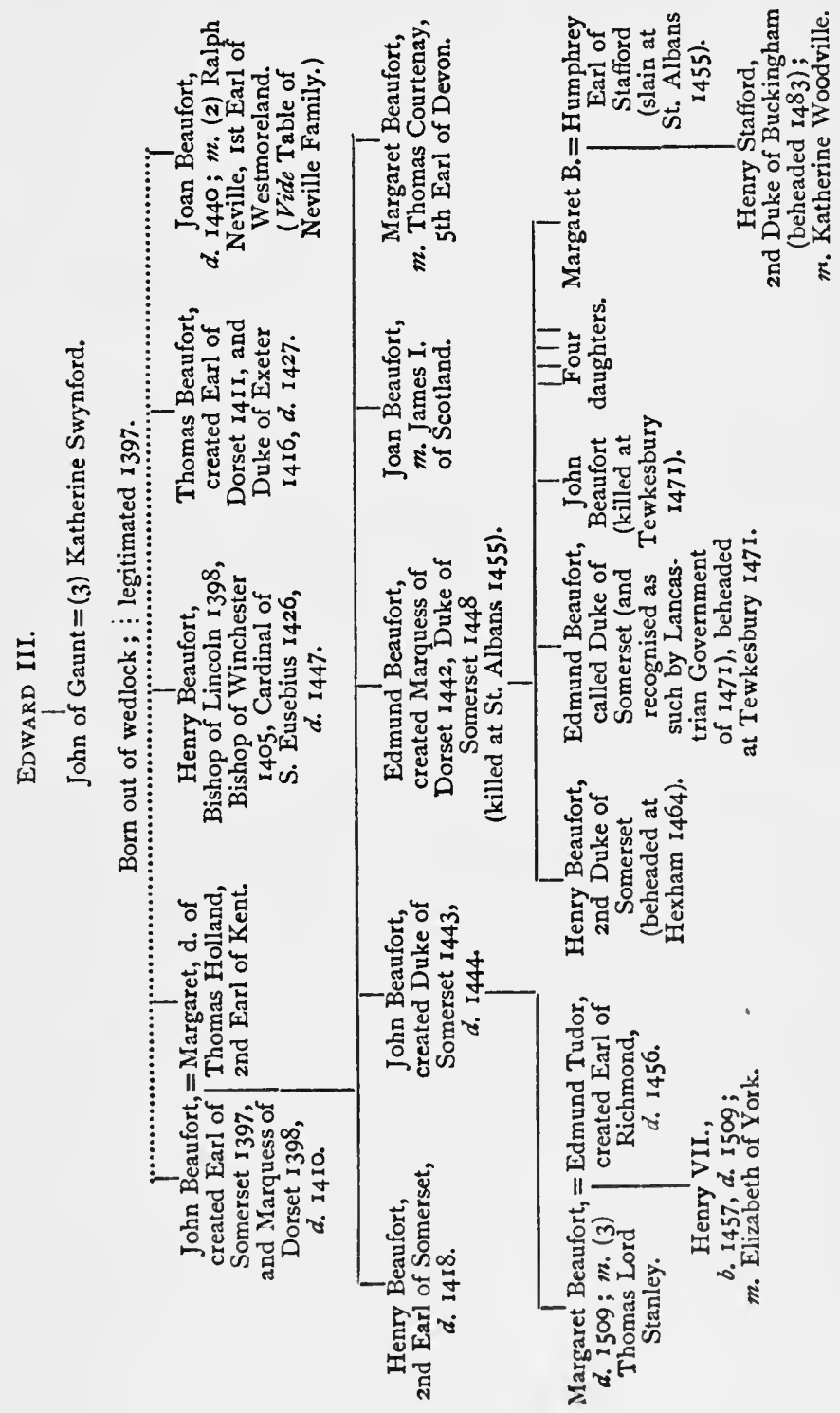


On this table exercises of the same type can be given, and human interest can be introduced if the teacher runs over it rapidly and gives a few details about each personage, thus bringing home to the class that the Beauforts were a united family and an important factor in the politics of the time. Here the Dictionary of National Biography is a great stand-by if the teacher is fortunate enough to have access to it.

For entering in the boys' notebooks a simplified form of such a genealogy as the first one given is desirable.

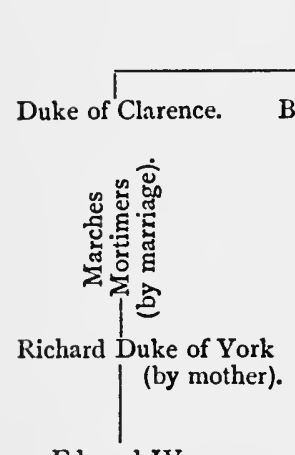

Edward IV.
EDWARD III.

Simplifications of this kind are also desirable in a more formal scheme, to avoid overcrowding. The following is a good example and is of additional interest because it illustrates in a striking manner the violent end that was the lot of those who had any claim to the throne. With this genealogy on the wall there are many opportunities of spending a few moments over the deaths of the Poles and the Buckinghams. 


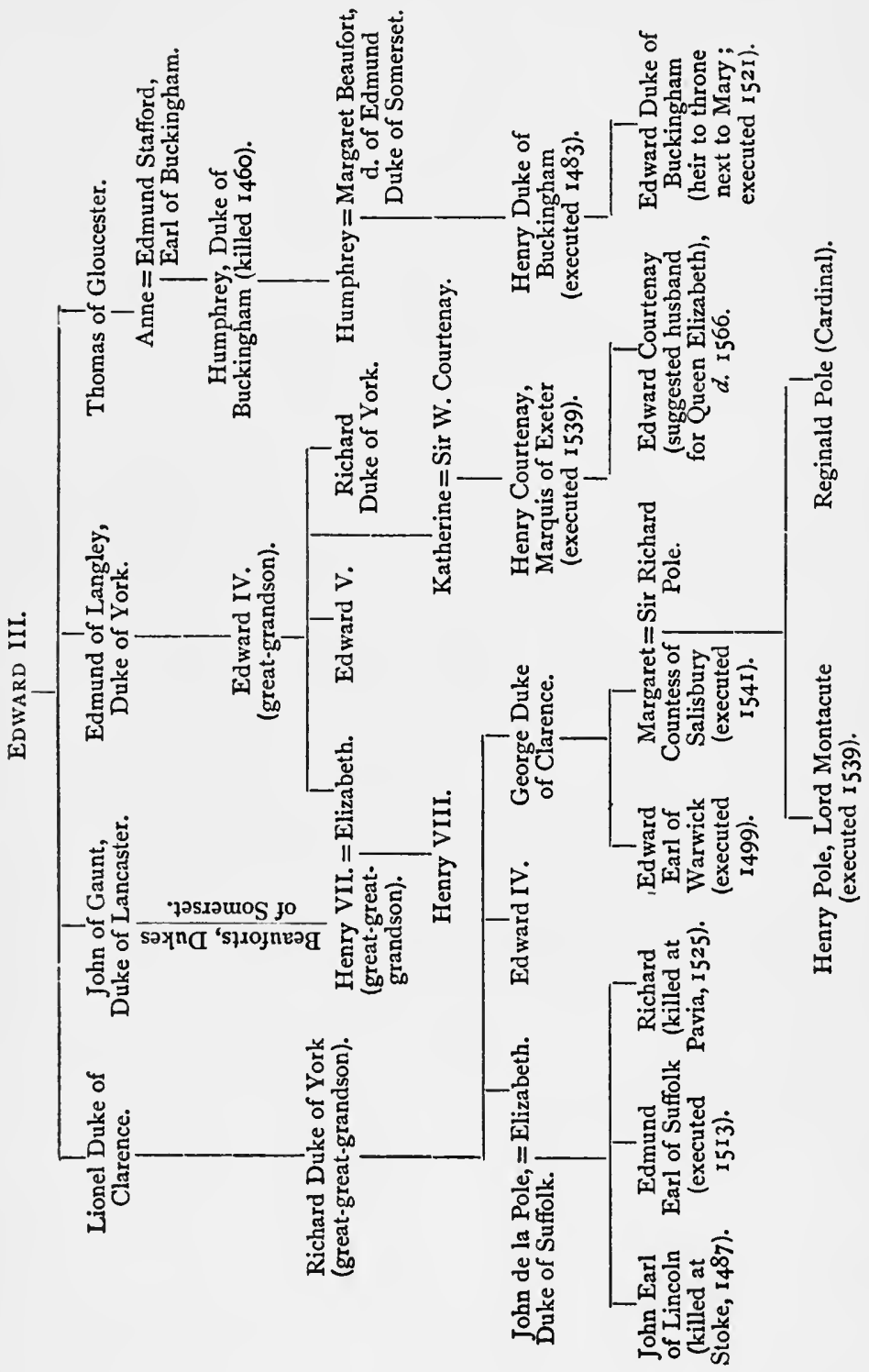


It remains to consider the most obvious method of concrete illustration, the use of maps and pictures. For all history teaching an outline map of England or of Great Britain and Western Europe on a blackboard sheet is highly desirable. On this the routes of armies and the journeys of princes can rapidly be sketched and distributions of population can be indicated. No word of mouth explanation will bring home to a class the reasons for the Earl of Warwick's influence in the fifteenth century so well as a map of England on which his own estates and those of his relatives are indicated by bold crosses in chalk ; the life history of Margaret of Anjou cannot be summarised so effectively as by an itinerary drawn on the map, with dates affixed, of her journeys between France, England, and Scotland. Further illustration of this is unnecessary, but it may be feared that the ease of the method has not ensured its common use.

Of the employment of portraits and other pictorial illustrations it is not possible to speak at length in this book, and the general remarks that can be made on the subject are few. Here it may suffice to note that there should be a good supply of portraits both in the pupils' text-books and source-books and on the walls of the class-room, and that the pupils should be made to study them carefully. Much interesting work may be done in connexion with the coats-of-arms and insets of various kinds to be found in old engravings, and these opportunities should not be neglected. In recent school-books the number of portrait illustrations has been increased and their quality has improved; but the teacher is often hampered by the omission on the part of the writer to state the source from which the illustration was taken. 


\section{CHAPTER VII}

THE ORGANISATION OF HISTORY TEACHING

WHERE is the time to come from for the methods here recommended? This question, which doubtless occurred to the reader during the first few chapters, has by this time been definitely formulated in his mind, and the question is a pertinent one. Exercises have been suggested whose working and revision with a class may easily occupy the whole of a preparation hour and of a school hour; the average number of hours devoted to history in the school year is as a rule not more than 72 , and sometimes only half this number, while not unfrequently a stretch of from 200 to 400 years has to be covered in the time. When periods of this length are in question, merely to get through the text-book with some explanatory remarks and to make the class write a few papers will tax the strength of even a methodical teacher.

Before proceeding to answer our question it may be well to pass in review a few educational positions that commend themselves to the common sense of those whose experience of boys is wide.

The subjects of instruction in school are not taught in order that at the conclusion of the course a boy may have an expert knowledge of them. This is rendered 
impossible, even if it were desirable, both by the number of subjects taught and by the boy's instinct of selfpreservation which apparently leads him to forget almost everything that he learns as soon as the examination is over. ${ }^{1}$ It follows from this that school studies must be looked upon as a preparation for or prolegomena to work that is to come later, whether this is the expert study of a special subject for professional or scientific purposes, or the general conduct of life in a business calling. In consequence all attempt at giving a complete presentation of any subject must be relinquished. The teaching should be sufficiently wide for the pupil to gather some idea of the scope of the subject and the relation in which it stands to other subjects, and sufficiently intensive to introduce him to the methods of reasoning or of manipulation peculiar to the subject. It should thus give him some mental training while at the same time adding to his stock of ideas. The function of the teacher is here an excessively delicate one, since he has to use his subject as an instrument for training his pupil, and has at the same time to preserve its scientific aspect. If one side of this process is neglected, or if one side is unduly pressed, the subject may become valueless as a school study. In attacking a problem of this kind it is above all essential to have had a considerable experience of the class-room, to have acquired that sixth sense of school-masters, a feeling for the aspect of a subject that makes boys think and work with zest; and it is precisely upon these questions that the specialist in the

I It may surprise those who have never taught to hear that a boy, and by no means an exceptionally stupid boy, may fail after the summer holidays to remember not merely the details, but even the outline of the work done in a school study during the previous year. 
subject whose acquaintance with boys is small is inclined to lay down the law with assurance. A pamphlet by Professor Tout, recently printed by the Historical Association, affords a good illustration of this, and a brief consideration of some of the conclusions reached in it will clear the ground for the argument of this chapter. ${ }^{1}$

Professor Tout's argument may be given briefly in his own words :- "The ideal of the teacher should be so to plan his historical course as to give his pupils a broad sweep of historical development, and not to drill them in the details of any of the corners of history." "We must therefore in the necessity of the case rigidly limit ourselves to outlines and definitely set our face against the detailed study of special periods. If we do not, we fail to accomplish the most primary objects for which all historical instruction is given." The period differs from the outline only in conveying more detail. "A period has to be got up in a text-book, which differs from smaller text-books only in being more detailed and therefore more wearisome," and Professor Tout questions the value of "a few lurid patches of detailed knowledge in the midst of a dark background of profound ignorance." 2

1 Outlines v. Periods, by Professor T. F. Tout, Professor of Mediæval and Modern History in the University of Manchester, 1907.

2 Among the advantages that Professor Tout imagines to be claimed for the "period" are the following: (1) It is more interesting. (2) It prevents superficiality. (3) It is easier to teach. (4) It is the easiest way to score marks in examinations. (5) It enables one to show the relations of cause and effect. (6) "It gives the scholar that drilling in detailed knowledge which trains the mind almost as much as a course of irregular verbs or of syntactical rules." These, it must be understood, are not Professor Tout's own arguments, indeed he proceeds to 
Now no one is likely to deny that a course in history should convey a notion of the broad sweep of historical development, but there seems to be no adequate reason for concluding either that we must definitely set our faces against the detailed study of special periods, or that "a period must be got up in a text-book which differs from other text-books only in being more detailed." For the moment, however, these two points may be left on one side. The main argument seems to be that an outline of general history should be given, and in this connexion the programmes of work prescribed for French and for Prussian schools are alluded to with approbation. It will therefore be well to examine these programmes in detail.

demolish them. But he evidently considers them plausible, and they are therefore full of interest as indicating the general attitude towards educational reasoning of the type of academic mind that in the long run often controls our school curricula. Of these arguments $I$ and 2 may be passed. 3 is an extraordinary statement unless the definition of a period given by Professor Tout (and quoted above) is adopted. 4 is correct only on the assumption that no examiners understand or are competent to learn their business. 5 may be passed. 6 is valuable as a key to the writer's mind. Surely no one has ever claimed that a drilling in detailed knowledge trains the mind. Not even the most abandoned advocate of classical study for its formal value has ever argued that "a course of irregular verbs or of syntactical rules" trained the mind per se. The application of the rules in worrying out a text or in writing composition may do so, but not the drilling in detail. 
Syllabus of History for Prussian Secondary Schools

\begin{tabular}{|c|c|c|}
\hline Class. & $\begin{array}{l}\text { No. of } \\
\text { Hours } \\
\text { Weekly. }\end{array}$ & \\
\hline VI. & I & Biographies from German History. \\
\hline V. & I & $\begin{array}{l}\text { Stories from the legends of classical antiquity : Greek, } \\
\text { up to Solon; Roman, up to the War with Pyrrhus. }\end{array}$ \\
\hline IV. & 2 & $\begin{array}{l}\text { Greek History up to the death of Alexander the Great. } \\
\text { Roman History up to the death of Augustus. }\end{array}$ \\
\hline III. B & 2 & $\begin{array}{l}\text { The Roman Empire under the Great Emperors. } \\
\text { German History from the first contact of the Germans } \\
\text { with the Romans up to the end of the Middle Ages. }\end{array}$ \\
\hline III. A & 2 & $\begin{array}{l}\text { German History from the close of the Middle Ages up } \\
\text { to Frederick the Great, with particular attention to } \\
\text { the History of Brandenburg and of Prussia. }\end{array}$ \\
\hline II. $\mathrm{B}$ & 2 & $\begin{array}{l}\text { German and Prussian History from Frederick the Great } \\
\text { to the present day. }\end{array}$ \\
\hline II. $\mathbf{A}$ & 3 & $\begin{array}{l}\text { The chief events of Greek History up to the death of } \\
\text { Alexander the Great, and of Roman History up to } \\
\text { Augustus, with references to Oriental History. } \\
\text { Revision of the chief events and dates of German } \\
\text { History. }\end{array}$ \\
\hline I. $\mathrm{B}$ & 3 & $\begin{array}{l}\text { The most important of the Roman Emperors. German } \\
\text { History up to the end of the Thirty Years' War. } \\
\text { Revision of the chief events and dates in ancient history. }\end{array}$ \\
\hline I. A & 3 & $\begin{array}{l}\text { The history of Prussia and of Germany from the end of } \\
\text { the Thirty Years' War to the present day. }\end{array}$ \\
\hline
\end{tabular}

With all the periods of modern History, European history is to be taught so far as it is necessary for the understanding of German history.

\section{Extract from the instructions to teachers:-}

"For the teaching of history from the IV. Class to the Upper I. the following apparatus is necessary: Text-books providing a continuous narrative, a historical atlas, a scheme of the dates that have to be learned, which may also serve as a basis for revision, pictures and other suitable matter to give life to the pupils' historical ideas.

"As far as is possible the pupils must be practised in the history lesson in giving in their own words a connected narrative of what they have learned." 
Syllabus of History for French Secondary SCHOOLS

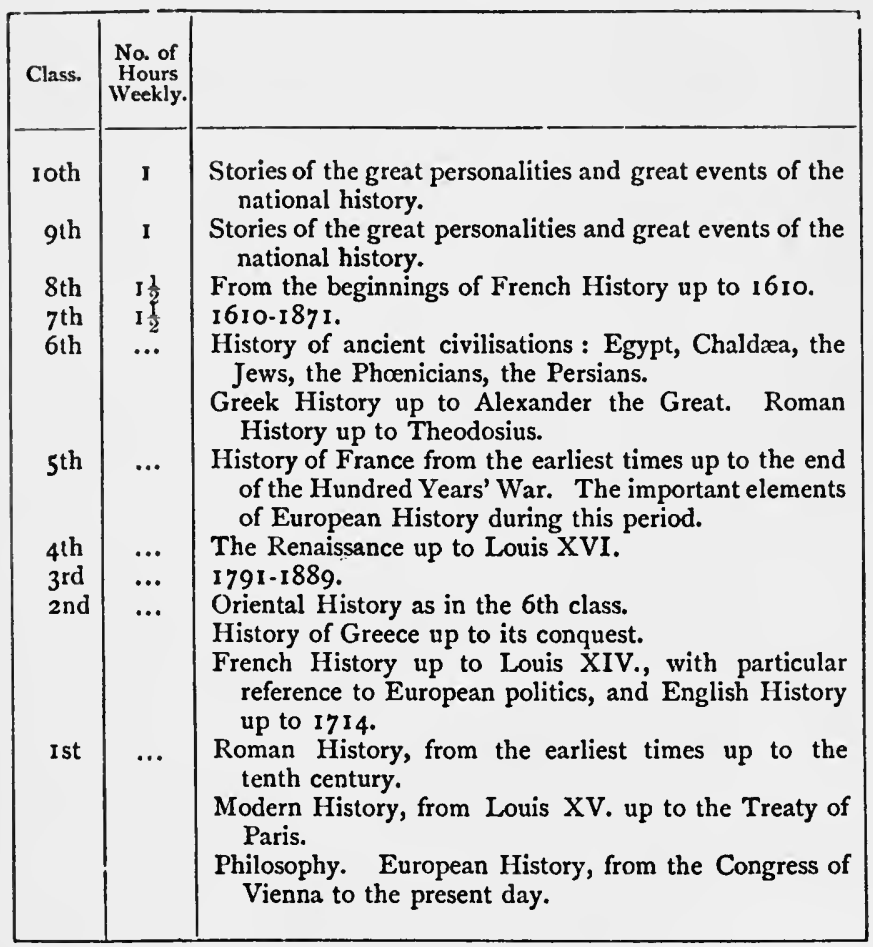

Method suggested for classes up to the 7 th. Short summaries to be dictated. Simple stories to be narrated. Short lectures.

\section{Complete Syllabus for the 7 th Class (Average AGE ABOUT 12)}

Louis XIII. and Richelieu. The siege of Rochelle. Execution of Montmorency. The war against the Spanish. Condé at Rocroi. 
Distress at the time of the Fronde. Charity of St. Vincent de Paul.

Louis XIV. The Court at Versailles. Colbert, the merchants, the artisans, and the peasants. Turenne in Alsace, Jean Bart. The revocation of the Edict of Nantes. The Duke of Anjou proclaimed King of Spain.

The last years of Louis XIV. Distress in the kingdom.

Louis XV. Maurice de Saxe at Fontenoy. Dupleix at Pondicherry. Montcalm in Canada.

Louis XVI. and Turgot. Franklin and Voltaire. La Fayette in America. The fight of the Belle Poule. Death of la Pérouse.

The Constituent Assembly. The deputies playing tennis. Mirabeau and the Marquis of Deux-Brézé. The taking of the Bastille. The night of the 4th of August.

The festival of the Federation. The flight of the King and his return to Paris.

The voluntary enlistments. Proclamation of the Republic. Valmy. The National Convention. The Death of the Girondins. Carnot, the Republican Armies. Jourdain at Fleurus.

The Directory. Bonaparte at Arcole; in Egypt. Masséna at Zurich.

The Consulate. Crossing of the Great St. Bernard. Desaix at Marengo. Moreau at Hohenlinden.

The Empire. Napoleon Emperor. Austerlitz. Jena. Napoleon and Alexander of Russia at Tilsit. The King of Rome. The retreat from Russia. General Elbé at the Beresina. The conscripts of 1813 at Lutzen. Farewell to Fontainebleau.

The hundred days. The Guard at Waterloo. Napoleon at St. Helena.

Comparison between the frontiers of France in 1800 and in 1815 .

France from 1815 to 1848 . The French in the War of Greek Independence.

Taking of Algiers. Taking of Constantine. Bugeaud and Abd-el-Kader. The French in the War of Belgian Independence. The first steam-boats and the first railways. 
The Revolution of $\mathrm{I} 848$. Universal Suffrage. Lamartine at the Hôtel de Ville.

The Coup $d^{\prime}$ Etat of December $\mathrm{r} 85 \mathrm{r}$.

The second Empire. The Crimean War. Sebastopol. The French in the Italian War of Independence. Solferino. The electric telegraph. The great Exhibitions of 1855 and I867. The opening of the Suez Canal.

The Franco-German War. The Invasion of Alsace. The battles round Metz. Sedan.

The proclamation of the Republic. The siege of Paris. Gambetta at Tours. Chanzy and the army of the Loire. Faidherbe and the army of the north. Denfert-Rochereau at Belfort. The Treaty of Frankfort. Thiers and the redemption of the country.

Comparison between the frontiers of France in 1815 and in 1871 .

\section{Complete Syllabus for the 4th Class (Average AGE ABOUT I5)}

Maritime discoveries and establishment of colonies. Spices and the precious metals.

The Renaissance. The artists and their works.

State of Western Europe at the end of the fifteenth century. France, Spain, Germany, Italy, and England.

The struggle between the houses of France and Austria. The empire of Charles V.

The Reformation. Luther and Calvin. Anglicanism. Catholic reform. The Jesuits. The Council of Trent.

The religious wars. Calvinism in France. Massacre of Saint Bartholomew. The League. The Edict of Nantes. Part played by Spain under Philip II.

General Character and Result of the Thirty Years' War. The Treaties of Westphalia and of the Pyrenees.

Establishment of absolute monarchy in France. Francis I Henry I. Richelieu. Mazarin.

Louis XIV. Foreign policy. The court, the government, policy in religious matters. Revocation of the Edict of Nantes. Colbert ; industries, trade, navy. 
Society in the seventeenth century. The clergy, the nobility, the towns, the peasants.

Material condition of France during the reign of Louis XIV.

French art in the seventeenth century. The great writers. The chief buildings.

England in the seventeenth century. The revolutions of 1648 and 1688 .

France under Louis XV. Absolute monarchy. The Parliaments.

England in the thirteenth century. The parliamentary régime.

Prussia. Frederick II.

Austria. Maria Theresa and Joseph II.

The Russian Empire. Peter the Great. Catherine II.

Foreign policy in the eighth century. Struggle between Prussia and Austria. Partition of Poland. Struggle between France and England. India and Canada.

France before the Revolution. Material condition. Town and country. New ideas. Public opinion and the government.

Louis XVI. The financial crisis. The convocation of the States General.

As an examination of these syllabuses shows, both the German and the French schemes ensure a complete course of Universal History for the pupils in secondary schools. There are some differences of detail. In the German schools this course is gone through twice; in the French schools the course of Universal History is covered twice and that of French History three times. In the French course is included a sketch of Eastern History ; in the German course this does not appear in the History syllabus, as the subject-matter is given in connexion with the Scripture lesson.

To one who turns to these syllabuses from the fragmentary and ill-arranged provision made for history in some English secondary schools the contrast is a striking 
one, and the advantage seems to be wholly on the side of Germany and France ; but a little further consideration raises questions. The syllabuses are full and exacting: in the French scheme they are markedly so, as can be seen from those quoted in full for the 7 th and 4th classes. It is evidently intended that the successive periods of history shall be displayed before the pupils on a uniform scale, and that the amount of detail is to be considerable; while from the general tenor of the instructions given it appears that the attitude of the class is to be mainly receptive.

Now in both Germany and France, especially in the latter country, the complaint is loudly made that the schools tend to overburden the memory of their pupils, the result being fatigue and overpressure without any counterbalancing training of faculty. Given syllabuses of this length and the conception of a uniform scale of presentation, it is difficult to imagine any other result. Let any one select one of the periods above suggested for a year's work, and consider how much time he will have for the kind of detail that is desirable, for considerations of cause and effect, of motive and of character, after he has worked through the topics of a rigid syllabus. For the type of work that has been suggested in previous chapters there is no time whatever. For the teacher a methodical presentation based on the text-book, and for the pupil the memorising of facts is the almost certain result of syllabuses such as these; and let it be repeated that the facts learned are soon forgotten, that the mastery of a condensed syllabus does not induce the interest which leads to private reading at a later stage, and that the whole business may easily degenerate into cram of the most unsatisfactory kind. 
In contrast to such a method a more effective mode of teaching is to treat small portions of a subject intensively so that they stand out with vividness against a background of routine-work, and in a setting that gives their relation to the rest of the subject. Without doubt it is necessary to give to a middle-school boy some notion of the sequence of events in Universal History. A knowledge of a particular period is no knowledge at all unless it stands in close connexion with the period that precedes; an acquaintanceship with English History is but halfmade unless its relation to European History is grasped; an understanding of events in England down to 1830 will not attain fruition if the history of recent social and political movements is omitted; the whole conception of chronological sequence may be destroyed if the years between the Emperor Augustus and Alfred the Great are left as void of content as the "unexplored territory" on the older maps of Africa. To admit this, however, is not to accept Professor Tout's proposition. Let an outline be given by all means, but let it be realised that it is there to serve as a setting for the period, that the presentation of history to boys on a uniform scale is the surest way of reducing it to an arid memory subject, that there are periods of mediæval history which for school purposes can be covered in a couple of half-hour talks, and sections of European History that may be presented and explained in a couple of school periods. The device of combining a special with a general period for a year's work, or of selecting out of a period of fair length a certain number of topics or episodes which shall receive attention on a much larger scale is a legitimate and a practical solution of our difficulty. Let us consider some schemes of English History which 
embody this combination. They presuppose a preliminary sketch of English History, given in the years before 12 .

I. 12-I3. General period, from the departure of the Romans from Britain to 1307 . Special period, I I 54-I2 I6.

II. I3-14. General period, I307-I603. Special period, I 558-1603.

III. I4-I5. General period, I603-I7I5. Special period, 1625-1660.

IV. I5-16. General period, I715-1837. Special period, 1789-1837. French Revolution to Reform Bill.

V. I6-I 7. 1837-present day. Tariff Reform, Indian Mutiny, Economic History, Modern politics.

In this scheme it is intended that the general period shall be done in outline only, and that the bulk of the work shall be given to the special period. The special period need not, however, be studied with a uniform degree of intensity. A few remarks upon each stage will make this clear.

Year I. The special period is a short one; but apart from it there are a number of topics that need attention in detail and a good deal of concrete illustration. Feudalism, the results of the Conquest, Domesday Book, the Church and the Crown, the crusades, social life, the coming of the friars, and the legislation of Edward I. are among these. The special period selected, containing as it does Henry II., Becket, Richard I., King John and Magna Charta, forms a 
good centre from which, working backwards and forwards, we can trace the origins and developments of these various topics.

In Year II. the general period is long, and contains such important topics as the Hundred Years War, the Black Death and its economic results, the growth of Lollardy, and the Wars of the Roses. Here a topical treatment is necessary. A few episodes in the Hundred Years War must be treated in detail, the rest in the merest outline. Lollardy can be centred in Wyclif, whose personality will repay careful work. The Wars of the Roses need great skill in handling, they are of importance as indicating a phase through which England was destined to pass, but to only a few episodes can much attention be given. One battle, say Towton, can be treated at length as typical of the rest; Warwick's position and in particular the influence acquired through the fortunate marriages of his house must be made clear ; stress must be laid on the social life of the times in connexion with the Paston Letters, and in the literature hour some of Shakespeare's historical plays may be read. Otherwise there is no time for more than a sketch of the sequence of events. It is desirable, however, to give as much time as possible to the Reformation under Henry VIII.

Year III. Here the general period is short, and there will be ample time for a detailed treatment of the special period, 1625-1660, Charles I. and the Commonwealth, a period that is of the first importance.

Year IV. Here in the general period, I71 5-I837, the Conquest of India, and the War of American Independence can be given only in outline, in order to leave time for a fuller treatment in the special period of the French 
Revolution and Napoleon in their relation to English politics.

Year V. Here a somewhat different treatment might be adopted. The class might well be reading some book in connexion with recent political or with economic history, and some of the teaching might approximate to lecture form.

In the scheme thus outlined it is supposed that the necessary European History is treated as occasion arises. No provision is made for Greek or Roman History, because to do so would either lengthen the cycle or make it necessary to compress the whole of English History into two or three years. If the cycle is lengthened in such a way as to allow two years for ancient history before modern history is begun, this gives a rotation for the history course of at least six years and makes it impossible for the pupil to go through his national history twice before the average leaving school age. It must also be remembered that under this arrangement the Roman history would be read by pupils of about 11-12 years of age, and that it would thus be impossible to correlate it with the reading of Latin historical authors.

A better arrangement would be to give an independent course of ancient history for, say, one period weekly.

12-14. A two-years' course covering a history of Eastern civilisation and Greek History up to Alexander the Great.

14-I6. A two-years' course covering Roman History up to the break-up of the Roman Empire and including a brief account of the Middle Ages.

Here from fourteen to sixteen at least the pupils 
would be reading a Latin text, either Livy or Cæsar's Gallic War, in connection with which much useful historical work might be done.

It is difficult to see how the scheme outlined above could adequately be covered without four periods weekly, three for the modern and one for the ancient history, and on modern sides or in modern schools this is not too much to ask for such an important subject. It would, however, be possible to reduce the periods of modern history to two by reserving one for the outline of the general period, and using the other for the treatment of documents in connexion with the special period. This arrangement would necessitate only three periods in all.

The next scheme suggested supposes that only two school periods weekly and one period of preparation can be found for history, and tries to make the best of an unfortunate situation.

I. I2-I3. Modern History-II54-I2I6. Henry II., Richard I., John (one period and one preparation weelkly).

Ancient History-Eastern civilisations and

Greek History down to Alexander the Great (one period weekly).

II. I3-I4. I4I3-I485. Henry V. to Richard III. (one period and one preparation weekly).

Roman History up to the break-up of the Roman Empire (one period weekly).

III. I4-15. 1558-1603. Elizabeth (one period and one preparation weekly).

Mediæval European History and revision of

English History (one period weekly).

IV. I5-16. 1625-I660. Charles I. and the Common- 
wealth (two periods and one preparation weekly).

V. I6-17. I789-1837. French Revolution to Reform Bill (two periods and one preparation weekly).

In this scheme it is intended that in each year the bulk of the time shall be devoted to the short period indicated, and that a mere skeleton of the remainder of English History shall be given. In this way with only two periods a week some useful detailed work might be done, while in connexion with the mediæval history of the third year many points in English History might be revised and amplified. The year devoted to events since I 837 which figured in the first scheme has disappeared, and for it must be substituted a few lectures given to the whole school; or a small book on Nineteenth Century History might be set as a holiday task.

It would be easy to multiply schemes of this kind, but little would be gained by doing so. They are intended only to make clear the exact nature of the problem, to bring into relief the necessity of, at all costs, reserving a small portion of the time for detailed work, on which exercises can be set, and to show that, if ancient history is included in the cycle and is not made to run parallel with it, the cycle becomes too long for practical purposes. In any case, the exact nature of the scheme adopted in a particular school must depend upon the organisation of the remainder of the curriculum.

It must also be remembered that in English schools the problem is not so simple as it appears on paper, as fortunately it is not the custom to promote whole classes 
yearly, but at certain stages at any rate to allow the cleverer boys to have terminal removes. As result a number of boys are promoted before they have completed the syllabus assigned for the year. This difficulty can to some extent be got over by arranging that whole sections of a school shall do the same period in a given year. Stages I., II., and III., for instance, as set forth above, might all do the first period of history in the first year, the second in the second year, and the third in the third year. Dislocation would then occur only when boys were promoted during the year from one section of the school to another. With this organisation there is the further advantage that it is possible to arrange for general lectures on the period to be given to the whole school section at once.

It is not likely that the experienced schoolmaster will fall into the error of believing that a full outline of history duly assimilated by the class will either give mental training or convey much meaning to them. With the historical expert the case is different. Each detail and each date awakens in him a number of associations and has in consequence $a$ wealth of meaning, and it is difficult for him to realise that to the boys' minds it conveys very little. To the expert the carefully arranged, symmetrical, and uniformly developed scheme appeals as the organisation of a deep knowledge which he already possesses : for the boy the sequence of statements that can so casily be learned and reproduced in the examination room may be little more than the headings of chapters that he has not read. Unfortunately, it is the expert who in some cases controls the making of schemes in accordance with which schools have to work. 


\section{CHAPTER VIII}

\section{HISTORY AND THE EXAMINATION SYSTEM}

THE process of examination is no new thing. There never has been an age when men of a certain type did not examine their own lives and conduct, bringing them to the touchstone of principles and of ideals; there never was a time when men's characters and talents were not scrutinised and judged by that sternest of all examiners, social opinion; in no country have rulers, teachers, writers, or pastry-cooks ever escaped criticism, and it is upon this criticism that their continued excellence has depended. We cannot, even if we will, avoid examination. It is an immutable law that shoddy work, low aims, and indifferent counsels sooner or later are discovered, are weighed in the balance and found wanting; and society is the gainer thereby. But to what extent society is the gainer by the modern development of the examination principle is perhaps doubtful. In matters of conscience, although selfexamination, if properly conducted, is always salutary, examination and inquisition by others is liable to produce duplicity and callousness instead of a sensitive candour. Let the argument be transferred from the domain of conduct to that of knowledge. The operations of learning and of teaching to which the crude methods 
of the external examiner are in this country applied so freely and so universally are just as delicate and as sensitive as the tenderest conscience, are quite as liable to have their growth checked and stunted, or to be developed in a direction which in the long run will be unprofitable.

It is only of recent years that this system of testing the results of teaching by a series of examinations from the age of 13 upwards has grown to such huge dimensions, and has been so readily acquiesced in by the whole teaching community. Has this growth worked for good or for evil? In the beginning the external examinations that now hold schools of a certain type in such a firm grip were probably an unmixed good. They compelled schools which taught only a little Latin, and taught that badly, to widen their curriculum and look to their efficiency. It is easy to criticise examination papers, especially those in English Literature and English History, but it must not be forgotten that these examinations have ensured that a boy of a certain age shall have read at least a play of Shakespeare and a novel by Scott, and shall not be wholly ignorant of the leading facts and dates of his national history. That they were needed at the time of their introduction is to a degree shown by their remarkable success. The British parent, profoundly sceptical as to the value of all intellectual instruction, and in particular as to the efficiency of the schoolmaster under whom he has placed his boys, looks on the external examination as a test of the competency not of the boy but of the school. There is a definiteness about marks and orders and classlists that, as compared with the platitudes which he hears from platforms on school speech-days, appeals 
strongly to him as a business man, and consequently the demand for certificates and examination results has grown so great that only those schoolmasters who are very sure of their position can resist it.

Further, it may be misleading to pass censure upon any examination paper or set of questions in the abstract. Much depends upon the school organisation that supplies the candidates who are to answer them, much upon the system of studies which leads up to the examination as a final test. If the teaching is really good and the pupils are not sent in prematurely, the examination may be taken in their stride, and the quality of the teacher's work is not affected; though in this case the need for the examination is not very evident. If, on the other hand, the organisation of a subject in the lower and middle forms of a school is poor, or if a series of examinations have to be passed for each of which the teacher may have to prepare his pupils in the subject-matter of a definite syllabus, and is given about a year to do it in, it is not difficult to see that the selection of the subject-matter is taken out of his hands, and that in many cases the method of imparting it is settled for him as well. He will have to administer his facts, and often, in addition, the inferences that his pupils should draw from them, as forcibly and as neatly as he can in order to cover the syllabus in the allotted time. In this case the quality of the teacher's work is affected, and in many cases adversely affected, as will be shown later.

Naturally the apologist for examinations assumes that the organisation which supplies candidates to them is a good one, and that in consequence the teaching is not subordinated to the examination. Alas! 
experience shows that the subject frequently remains unorganised, and that the matter covered by the syllabus is gone through in the one year previous to the pupil's entry for the examination; while as long as the daily papers publish lists of the successful candidates in the local examinations, and the public attach such importance to them, it shows an ignorance of human nature to hope that teachers, whose professional reputation depends almost solely on such results, will not conform rigidly to the methods by which they may be obtained. These methods are far from being despicable. They must be businesslike; they demand skill on the part of the teacher and work on the part of the pupil, and they thus embody a standard of strenuousness and of accuracy which is not without value. With certain subjects, however, of which history is one, working for examination may necessitate the omission of the very elements that render them of value, and it is therefore most undesirable that in the case of State-aided schools public money should be expended on such work. For this the reasons are as follows :-

I. When the subject of examination is a process the examination may serve as an adequate test of good teaching. If a boy is asked to write a piece of Latin prose, the quality of his work is a fair test of his master's skill in teaching. The power of solving complex problems in algebra is a sure sign that the teaching has been on right lines. With history, however, as at present examined, this is not the case. The questions set are chiefly a test of memory, and although a consideration of causal elements may be asked for, it is very difficult for the examiner to tell whether the inferences and causal con- 
nexions which are supplied by the boy in the examination room have actually been worked out by him, or, like the answers to questions of fact, are mere memory work.

2. To draw and select concise answers of fact from a fuller body of knowledge properly suffused with atmosphere is an extremely difficult task. It is as a rule beyond the capacity of the average boy. A pupil who has been taught to reason out his own train of cause and effect, who has assimilated a considerable background of information and with it a suitable atmosphere, and who therefore has been given an admirable basis for further historical study and an interest which may actually lead him to such study, may none the less make a poor show in the examination-room when pitted against one to whom the sequence of cause and effect has been neatly presented and who has been practised in writing answers of the kind required, but has not been ntroduced to any of the material that gives atmosphere or to the exercises that consume time. The younger the pupil the more likely it is that examination conditions will hinder the observance of a due proportion between schematised fact and atmospheric background.

3. The length of the periods demanded for some examinations in history and the uniform scale of presentation that is presupposed makes it almost impossible for the teacher to work on the lines that demand the most thought from the pupil.

A few examples of examination papers recently set will illustrate these points. 


\section{A}

[Candidates are required to attempt at least $\mathrm{ONE}$ question in each section of the paper, and not more than SIX altogether.]

A.

I. Trace the history of the divorce of Catharine of Aragon and show how it affected the separation from Rome.

2. Write short narratives of $(a)$ Wyatt's Rebellion, $(b)$ the loss of Calais.

3. Give a rapid sketch of English literature under Elizabeth.

B.

4. Explain the royalist successes in the first two years of the Great Rebellion (I642, I643). Why were they not maintained?

5. What were the objects aimed at by the Navigation Acts ? What results were achieved?

6. Give some account of the doings of the English navy during the reign of William III.

C.

7. Sketch the relations between England and Spain during the eighteenth century.

8. Give some account of the opposition to Sir Robert Walpole, and of the careers of the leaders of that opposition.

9. Trace in outline the principal stages in the French Revolution from its outbreak in 1789 to the establishment of the French Empire in 1804 .

D.

Io. Write a brief description of the following battles, and show their importance: Vinegar Hill, Vittoria, Navarino, Isandhlwana.

I I. Outline, with brief comments, the repressive measures of 18 rg (the six Acts).

I2. How did (a) the coup d'stat of $185 \mathrm{I},(b)$ the Crimean winter, affect the constitution of the British Ministry for the time being?

This paper is intended for candidates of from 16 to I 7 years of age, and covers the period 1485 to the death of Queen Victoria. The general criticism upon it must be that it tests the memory of the pupil more 
than any other mental process. As a natural result, since many of the important topics have been questioned on in previous examinations, the examiner has apparently been driven to avoid them. A teacher might have devoted much thought and labour to the more interesting topics in the reigns of Elizabeth and the Stuarts. His teaching would reap no reward in this paper. This avoidance of the questions set in previous papers must always be a feature of memory examinations; but who ever heard of an examiner who refused to set a problem involving quadratic equations because a similar problem occurred in the last examination? School teaching must always lay stress on the obvious and important matters, and if the examiner has to avoid them, there is something wrong with the system. As a whole, the paper is likely to discourage all teaching that is not the most deliberate preparation for the examination-room. It is emphatically a text-book paper in which the expenditure of time on atmosphere or on exercises that require reasoning is not likely to increase the candidate's chances of success. Even taking the paper on its own level, it is far from reaching a high standard. As already noted, the most important periods are scarcely touched upon. The question on the "loss of Calais" is ambiguous. It may either ask for a narrative of the previous history of the English occupation leading up to the loss of Calais, or it may demand a detailed account of the taking of Calais. If the latter interpretation is correct, the question is a bad one. It is on a topic of which the details are relatively unimportant in comparison with a number of the topics which are passed over. It might, however, easily be rendered less vicious by asking, "Account for the loss 
of Calais. To what extent may Queen Mary have over-estimated its importance to England?"

Question 3. Give a rapid sketch of English literature under Elizabeth.-This represents the worst type of question that can be set. It is a direct encouragement to teach lists of the names and characteristics of authors that the pupils have not read, and this is useless and senseless cram of the most unprofitable kind. It is a saddening reflection that many competent and earnest teachers have to spend their lives in preparing pupils to deal with papers of this kind, that a great university countenances such examining and derives a pecuniary profit from it, and that the money which ratepayers contribute towards secondary education with such reluctance may be devoted to work of which such papers determine the quality. It is examinations of this type which deter many able men from entering the teaching profession.

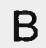

[Candidates may answer ANY SIX, but NOT MORE THAN SIX, of the following eighteen questions. They should take SPECIAL CARE that each answer bears the same number as the question to which it is an answer.]

$$
\text { I. } 1066 \text { to I } 509 \text { A.D. }
$$

I. Point out the difference between the conduct of William I. towards Lanfranc and the conduct of William II. towards Anselm.

2. What do you know of Matilda, the daughter of Henry I., and of Eleanor, the wife of Edward 1. ?

3. What were the grievances which caused the Barons' War in the reign of Henry III. ?

4. When, and why, was the battle of Bannockburn fought? What were its results?

5. Mention the actions from which the Good Parliament and the Merciless Parliament took their names. 
6. Give an account of either the career of Margaret of Anjou, or the rebellion of Lambert Simnel.

II. 1509 to 1688 A.D.

7. Describe the events which brought about the rise and the fall of Thomas Cromwell.

8. What was Elizabeth's object in her ecclesiastical policy? How did she deal with Roman Catholics and Puritans?

9. What gave rise to the Gunpowder Plot? How was it discovered, and what became of the conspirators?

Io. Write an account of the invasion of the Scotch which ended in the battle of Worcester. What were the consequences of its failure?

11. Give the provisions of the Test Act. When, and why, was it passed?

12. State what you know of either the Habeas Corpus Act, or the trial of the Seven Bishops.

$$
\text { III. } 1688 \text { to } 1832 \text { A.D. }
$$

13. Give the dates and the chief provisions of any two of the following:- the Treaty of Ryswick, the Grand Alliance, the Septennial Act, Walpole's Excise Scheme.

14. Describe briefly the rebellion of 1745 .

15. State with regard to each of the following battles the date, the combatants, and the results:-Bunker's Hill, Camperdown, Minden, Plassey, Quiberon Bay.

I6. Who was John Wilkes? With what agitations and reforms was he connected?

17. Why did England and France go to war in 1793 ?

18. Describe either the Waterloo campaign or the work of Canning in the management of foreign affairs.

This paper represents an ingenious attempt to permit candidates to offer either the whole of English History or a shorter period. On this it may be remarked that if a candidate offers the period I066-1832, eighteen questions does not give a sufficient choice; while if he selects any one of the periods into which the whole stretch of history is divided, he is offered no choice at all. 
Like the first example given, the paper appeals to the memory of the pupil and to little more. Questions upon the conduct of William II. towards Anselm, upon the candidate's knowledge of Matilda or of Eleanor, or of the events which brought about the rise and fall of Thomas Cromwell, can be committed to memory from the manuals arranged for this purpose. For purposes of illustration, it may be well to consider two condensed biographies taken from such a manual, an excellent one of its kind.

\section{ANSELM [1033-1 109]}

Anselm was an Italian, being born at Aosta (1033), but he entered a monastery first in Burgundy, and after a short stay there went to the famous Norman abbey of Bec, whose prior at this time was the celebrated Lanfranc. When Lanfranc left Bec, he was succeeded as prior by Anselm; but he still saw something of his old superior, for the abbey's business often took him to England.

When Lanfranc died (1089) the Sce of Canterbury remained vacant for some years, in order that the King (William II.) might enjoy its revenues. But an opportune illness in 1092 led the King to offer Anselm the vacant see, and Anselm, despite his protests, was forced to accept it. As soon as the King recovered from his illness, he hastened to quarrel with his new archbishop, whose present to him on taking over the see he considered intolerably small. When Anselm declared his intention of proceeding to Rome to receive the archbishop's pall at the hands of Pope Urban, the King replied by refusing to acknowledge Urban as Pope at all; and when, after the Council of Rockingham, the King recanted, and sent for the pall to bestow it upon Anselm, the latter refused to receive it at a layman's hands. However, a compromise was arrived at, and Anselm settled down to the work of his see. But when a quarrel about Anselm's feudal position broke out later, Anselm left England for Rome (1097). He stayed on the Continent till the accession of Henry I. made it possible for him to return to England. But in 1103 he went upon his travels again rather than yield in the matter of investitures. Briefly stated, Henry demanded homage and the right to invest Anselm with the symbols of his office; Anselm, following in this 
the opinion of the Continental Church, thought this an insufferable indignity to the Church. However, two years later, king and archbishop arrived at a compromise which was afterwards followed throughout Europe; this was that ecclesiastics were to do homage for the temporal possessions of their office to the temporal power, but were to receive the spiritual symbols of their offices at the hands of an ecclesiastic representing the Church.

Anselm was then a scholar, an organiser, an administrator, and a statesman; a man of singularly pure aims, he was ready to abide by what he thought a good principle, and in the age in which he lived a victory over the power of kings might well seem a victory for good over force and tyranny.

\section{Thomas Cromwell [d. I 540]}

After a varied and adventuresome life in Italy, Venice, and the low countries as soldier, clerk, and lawyer, Cromwell in 1524 entered the service of Cardinal Wolsey. His loyal defence of his disgraced master attracted the King's notice, and after Wolsey's fall he passed into Henry's service. It was he who first suggested to Henry that he should take the divorce question and the government of the English Church into his own hands; as a reward he was made a member of the Council and soon became Chancellor. When Henry had acted on his advice by declaring himself Supreme Head of the Church, Cromwell became his Vicar-General, or representative in Church affairs. In that capacity he ordered a visitation of the monasteries and secured the suppression of most of them. He was actuated chiefly by two motives; he wished to make the King absolute, and to use the power thus gained to promote the work of the Reformation. But he was working too zealously, and his vigorous measures brought about a reaction. Rebellions broke out, and the King himself grew alarmed, and consequently passed the Six Articles into law. Cromwell, however, pursued his policy by trying to bring about an alliance between Henry and the Protestant princes on the Continent; to secure this he persuaded the King to marry Anne of Cleves, niece of the Elector of Saxony, the leader of the German Protestants. But not only was the marriage itself a dismal failure, but nothing came of the political situation of which it was a part. Cromwell was arrested shortly afterwards (I 540) on a charge of high treason, was attainted, and condemned and executed without being allowed to say a word in defence. His fall was a triumph for the supporters of the old religion, and was 
not unpleasing to the mass of the people, who groaned under his severe taxation and had little sympathy with his reforming zeal.

Summarising biographies of this kind have their value if the historical matter with which they deal has been taught in a proper and leisurely manner, but they are thoroughly vicious if success in examination depends upon learning them prematurely. When only fifteen minutes is allowed for each question, it is improbable that the average boy of I4-I 5 will do himself justice, unless undue attention is given to the mastering of such summaries.

To return to our paper. In setting examination papers it is axiomatic that, if alternatives are offered, they should be of equal difficulty and importance. Question 6 is an offender in this respect. The candidate is asked to describe the career of Margaret of Anjou or the rebellion of Lambert Simnel. The career of Margaret covers the Wars of the Roses, and to describe it a good knowledge of the detail in this period is necessary. Even then it would be a difficult thing to give an adequate description of it in fifteen minutes. In comparison with this the detail of Lambert Simnel's Rebellion is simple and of little importance. A similar lack of equivalence is to be found in Question 18, when the candidate is asked to describe either the Waterloo campaign or Canning's foreign policy. In general this paper is disappointing, since it offers little encouragement to the teacher to teach slowly and make his pupils think. 
C

[Candidutes are expected to answer SIX, and not more than SIX, guestions. More marks can be obtained on either Question 1 or Question 2 than on any of the others.]

I. Write short notes on the following :-the battle of Otterburn, the rebellion of Jack Cade, the rebellion of Perkin Warbeck, the Field of Cloth of Gold, the Spanish attempt on Ireland.

2. Give some account of the character and career of any two of the following:--King Henry V., Warwick the Kingmaker, Cardinal Wolsey, Northumberland the Protector.

3. Trace briefly the success of the House of York through the Wars of the Roses.

4. Give some account of the various claims of Henry VII. to the throne.

5. Explain clearly the nature of the religious changes made under Henry VIII., with special reference to-the Act for the Submission of the Clergy, the Statute of Six Articles, the executions of More and Fisher.

6. Give a short account of the following:-the First and Second Prayer Books of King Edward VI., the Reconciliation to Rome under Mary, the Acts of Supremacy and Uniformity of Queen Elizabeth.

7. On what occasions, and with what results, did Elizabeth engage in warfare with $(a)$ Scotland, $(b)$ France?

8. What maritime discoveries were made by English navigators in the Tudor reigns?

9. Trace the conversion of the Anglo-Saxons to Christianity.

10. Compare the successes of the Danes in England before Alfred's accession with those under Canute.

. I I. What effect on domestic history had the French wars of the reign of Edward III. ?

12. Give an account of the foreign policy of William III. How far was it in accordance with the true interests of England ?

I3. Trace the growth of the English power in India down to the overthrow of the Marathas.

14. What were the Corn Laws? Describe shortly the circumstances which led to their repeal.

This paper, intended for pupils of $14-15$, provides a special period, I399-1603, and also some questions on 
English History in general. It is on the whole better than either of the two preceding papers, in that it deals with essentials; and taken at their level the questions are good, with the exception of 9, Trace the conversion of the Anglo-Saxons to Christianity, which for boys of this age is unsuitable. As a guide to the teacher, however, the paper is bad. It tests the memory and nothing else. As has already been pointed out, when reasons and inferences are given in a candidate's answers it is not easy to ascertain whether he has been induced to make them for himself or has simply been given them; but in this paper no reasons are asked for at all, the questions are questions of pure fact, and as only fifteen minutes are available for answering each question, it is not likely that anything beyond the bare facts will be given. Some questions (No. 2, for example) can be answered directly from the summary-books. A part from this, the special period is far too long to allow of detailed work or of much thought on the part of the boy during the school year.

It is of little use to criticise defects without at the same time trying to point out a remedy. These papers have all been censured on the ground that they cater solely for the memory; but it is not here suggested that the memory should not be tested. A portion of every history paper for boys should consist of questions which are mere fact, date, genealogy, and sequence questions. This portion should be compulsory, and a moderate number of marks should be assigned to it; but the bulk of the marks should be given, and the position of the candidates decided, by questions of a different kind, intended to test reasoning power and ingenuity, and to ensure, so far as examination can ensure this, that the 
pupils shall have been taught in a certain way. Taking as the special period I399-I603 (since, although it covers far too much ground, that is the one selected by the paper which has just been considered), and assuming that candidates have three hours instead of one and a half in which to answer it, we may attempt to draw up a paper that to some extent will satisfy the conditions that have been laid down.

[Candidates are to attempt ALL the questions in Part I., and are to answer FOUR questions, but not more, fromi Part II.]

I.

I. Write short notes on the following : Sir John Oldcastle, John Duke of Bedford, Perkin Warbeck, Cardinal Wolsey, Cardinal Pole, Lord Burleigh, Robert Devereux, Earl of Essex.

2. Give a short account of three of the following: Henry V.'s Campaigns in France; The Earl of Warwick's relations with Margaret of Anjou; Henry VII.'s difficulties on coming to the throne; The Reformation in the reign of Henry VIII.; The Catholic Plots against Elizabeth; Drake's Voyage of Circumnavigation.

3. What events do you associate with the following places : Harfleur, Patay, Wakefield, Tewkesbury, Pavia, Cambrai, Carberry Hill, Plymouth?

II.

4. Asked about the teaching which the voice gave her respecting the salvation of her soul, she said that it taught her to govern herself well, to go often to church, and that it said she must go to France. And she added that the questioner would not this time learn from her in what guise the voice had appeared to her. She furthermore confessed that the voice told her twice or thrice a week that she must leave home and go to France, and that her father knew nothing of her departure. She also said that the voice told her to go to France, and that she could no longer remain where she was, and that the voice told her that she should raise the siege of Orleans.

To what does this refer, and in what year were these 
answers given? What do they tell you about the character of the speaker? Comment on the words in italics.

5. Letter from Edmund Clere to John Paston.

Blessed be God, the King is well amended, and hath been since Christmas Day, and on St. John's Day commanded his almoner to ride to Canterbury with his offering and commanded the secretary to offer at St. Edward's.

And on the Monday afternoon (29th December) the Queen came to him and brought my Lord Prince with her. And then he asked what the Prince's name was, and the Queen told him, Edward; and then he held up his hands and thanked God therof. And he said he never knew till that time, nor wist not where he had been whiles he hathe been sick till now. And he saith he is in charity with all the world, and so he would his lords were.

Date this letter and state to what event it refers. Explain any allusions that seem to you to need explanation. What is the value to the historian of letters of this kind?

6. At daybreak on the Monday following there were no chaplains present to perform divine service for King Richard, nor any breakfast prepared to revive his flagging spirits. Moreover, in the morning he declared that during the night he had seen dreadful visions, and had imagined himself surrounded by a multitude of demons. His face consequently, always haggard, seemed more livid and ghastly than usual, and he asserted that, to whichever side victory might be given, the issue of this day's battle would prove the utter destruction of the kingdom of England.

Comment on this extract from the Croyland Chronicle.

Why may Richard III. have been particularly liable to unpleasant dreams?
7. 1487 .
Lord Bacon, History of King Henry VII., ed. Lumby, p. I 5 . (1621.)

According to the lord chancellor's admonition, there were that parliament divers excellent laws ordained, concerning the points which the king recommended. 
First, the authority of the star-chamber, which before subsisted by the ancient common laws of the realm, was confirmed in certain cases by act of parliament. This court is one of the sagest and noblest institutions of this kingdom. For in the distribution of courts of ordinary justice, there was nevertheless always reserved a high and pre-eminent power to the king's council, in causes that might in example or consequence concern the state of the commonwealth; and if they were criminal, the council used to sit in the chamber called the star-chamber; if civil, in the white chamber or white-hall.

How far would Bacon's high opinion of the Star Chamber have been shared in the reign of Henry VII. by: (I) a turbulent noble; (2) a judge on circuit; (3) a well-fed, liveried retainer; (4) a parish priest; (5) a prosperous farmer; (6) a country armourer?

8. It may also please your most royal majesty to know how that yesterday there passed your Commons a bill that no person within this your realm shall hereafter keep and nourish above the number of 2000 sheep, and also that the eighth part of every man's land, being a farmer, shall forever hereafter be put in tillage yearly; which bill, if by the great wisdom, virtue, goodness, and zeal that your highness beareth towards this your realm, might have good success and take good effect among your lords above, I do conjecture and suppose in my poor, simple, and unworthy judgment that your highness shall do the most noble, profitable, and most beneficial thing that ever was done to the commonwealth of this your realm.

Comment on this letter written by Thomas Cromwell to Henry VIII. in 1534, making clear in your remarks :

(I) Whether it was likely that there would be any disagreement between the Commons and the Lords on the subject of this bill.

(2) What effect the bill would have $(a)$ on trade in wool, (b) on the trade in cloth, $(c)$ on the king's revenues, (a) on recruiting.

(3) Whether suppression of the greater monasteries a few years later would make the bill more necessary or less necessary. 
9. The next morning the Frenchmen entered and possessed the town. Thus have ye heard the discourse of the overthrow and loss of the town of Calais, an enterprise which was begun and ended in less than eight days, to the great marvel of the world, that a town of such strength, and so well furnished with all things as that was, should so suddenly be taken and conquered,-but most especially in the winter season, when all the country about, being marsh ground, is commonly overflown with water.

Comment on this and give the date of the event. Under what conditions was Calais most liable to be successfully attacked? How far was the loss of the town an advantage to England?

IO.

A. 1534 .

Albeit the king's majesty justly and rightfully is and ought to be the supreme head of the Church of England, and so is recognised by the clergy of this realm in their convocations, yet nevertheless, for corroboration and confirmation thereof, and for increase of virtue in Christ's religion within this realm of England, and to repress and extirpate all errors, heresies, and other enormities and abuses heretofore used in the same, be it enacted, by authority of this present parliament, that the king, our sovereign lord, his heirs and successors, kings of this realm, shall be taken, accepted, and reputed the only supreme head in earth of the Church of England, called Anglicana Ecclesia; and shall have and enjoy annexed and united to the imperial crown of this realm, as well as the title thereof, as all honours, dignities, pre-eminences, jurisdictions, privileges, authorities, immunities, profits, and commodities to the said dignity of the supreme head of the same church belonging and appertaining.

\section{B. 1559 .}

And that also it may likewise please your highness that it may be established and enacted by the authority aforesaid, That such jurisdictions, privileges, superiorities, and preeminences, spiritual and ecclesiastical, as by any spiritual or ecclesiastical power or authority hath heretofore been or may 
lawfully be exercised or used for the visitation of the ecclesiastical state and persons, and for reformation, order, and correction of the same and of all manner of errors, heresies, schisms, abuses, offences, contempts, and enormities, shall for ever, by authority of this present Parliament, be united and annexed to the imperial crown of this realm. . . .

Compare these extracts from the Acts of Supremacy of I534 and 1559, and point out any important difference that you notice, as well as the reason for this difference.

II.

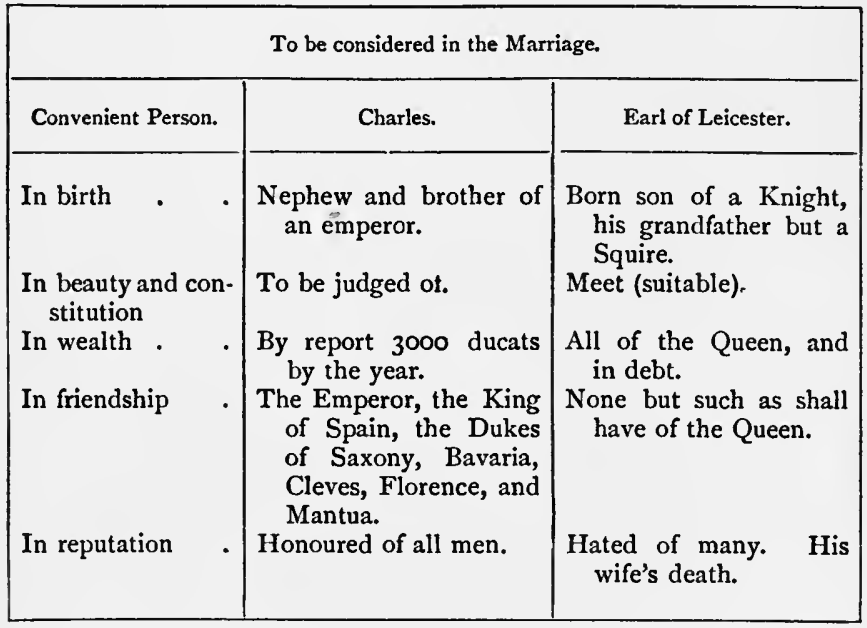

Explain this memorandum by Sir William Cecil. What light does it throw upon his character, and how might his personal welfare have been affected by Elizabeth's choice?

I2.

A.

SIRE-... If it be really decided to go to England itself I would only observe that this Armada, even when united with the troops of the Duke of Parma, which would at this season be embarked and carried over the straits with no small 
difficulty, does not seem to me sufficient to attempt this enterprise in the very heart of the winter. We have no harbours at hand in case of need, and the tide is extremely strong, the sea all open to the south winds. Nor, in my opinion, would it be such an easy matter to take the Isle of Wight, or any other harbour, for the shelter of our fleet, as is represented to your majesty by those who stake nothing on the risk, and have not been taught the difference between victory and defeat. ...

B.

Most REvEREND-The uncertainties of naval enterprise are well known, and the fate which has befallen the Armada is an instance in point. You will have already heard that the Duke of Medina Sidonia has returned to Santander, bringing back with him part of the fleet. Others of the ships have reached various ports, some of them having suffered severely from their long and arduous voyage. We are bound to give praise to God for all things which $\mathrm{He}$ is pleased to do. I on the present occasion have given thanks to Him for the mercy which $\mathrm{He}$ has shown. In the foul weather and violent storms to which the Armada has been exposed, it might have experienced a worse fate; and that the misfortune has not been heavier is no doubt due to the prayers which have been offered in its behalf so devoutly and continuously.

Compare letter A. from the Marquis of Santa Cruz to Philip II. of Spain in I 587 with letter B. from Philip II. to the Bishops of his dominions in I 588 , and discuss their bearing on the fate of the Armada.

It would be impossible for any boy to make much of Part II. in the examination paper sketched above unless he had been taught to use his wits upon the data from which history is written, and if examinations in history are necessary, the method here indicated would make them a test of ingenuity as well as of memory.

Doubtless such questions could not adequately be 


\section{8}

answered except by pupils whose training had been of a certain kind, and it must be confessed that, for the sake of illustration, the proportion of space allotted to them has been exaggerated; but a beginning might be made and the teaching of history might be influenced by the introduction into history papers of a few such questions with high marks assigned to them. 


\section{CHAPTER IX}

\section{HISTORY AND POETRY}

No one is likely to dissent from the general proposition that, where possible, full use should be made of those portions of English poetry which treat of historical events. If stirring episodes can be linked in the boy's mind with stirring verse, if the lilt and rhythm of majestic lines can be made the vehicle for a sequence of great events, if the struggles of nations or of classes can be presented in the words of the poets who lived through them, and whose songs echo the feelings of the time, there is here to our hand a combination of elements which it would be sheer folly to neglect. In this way better than in any other will events and phases of history be impressed upon the minds of middle-school boys, and receive a degree of illumination greater than could otherwise be given to them except by teachers of unusual gifts; they will linger in the memory long after the logical exposition of the class-room has faded from it, and will form rallying-points for a life-long interest in the national history.

All this is easy to write, and does not lack truth. It is the fatality of general statements that they are so often true with that kind of truth which seems to vanish and be dissipated as soon as we try to apply it in detail. 
As it is no business of this book to shirk detail, we must consider what are the difficulties for the craftsman at work in his class-room, and may treat them in connection with the questions: (I) What materials for such work exist? (2) Are we to use only verse that is contemporary with the events to which it alludes, or to utilise any good poetry that can be found? (3) What are to be our other principles of selection? (4) How are we to treat the poems when selected?

If we adopt anything approaching to an adequate standard of selection, it must be confessed that the material which we can find to work with is scanty. A comparatively small number of our best writers have treated in their best manner of historical events either of their own times or of former days. Some of the poems that might be suggested are mere doggerel, quite unworthy to place before boys; others from their form or from their spirit are not fitted for the age of pupil to which a poetic treatment of history is most suitable. Indeed this difficulty is more serious in England than in some other countries, since in the English language the gulf that separates true poetry from doggerel is considerable. In German the transition is more gradual and the German schoolmaster has a large storehouse of historical verse to choose from, all of it readable, allusive, and possessed of a rhythm which is inspiriting, and most of it at any rate passable, if it does not always rise to the level of fine poetry. Consider, for instance, the following stanzas by Gerok :-

Als Kaiser Karl sein Heldenschwert, die Leuchte der Germanen, Zur Ruh' gehängt im Siegessaal samt seiner Feinde Fahnen, Da sass der alte Held im Stuhl und hörte gern mit an, Dieweil sein Tagewerk vollbracht, war andere gethan. 
Und Eginhard und Alcuin, die mussten oft ihm lesen

Von Helden, die zuvor gelebt, von Zeiten, die gewesen.

Und sammeln ein und schreiben auf, aus deutschen Volkes

Mund,

Was von der Ahnen Thaten noch die Sage machte kund.

Am Mittagstisch bei Wild und Fisch, die Tafel ihm zu würzen, Um Mitternacht, wenn er erwacht, die Stunden ihm zu kürzen, Lag ihm zur Hand manch alter Band, manch köstlich Pergament,

Weil jugendlich der greise Held von Wissbegierde brennt.

Denn in des Volkes Kindermund, in Lied und Spruch der Alten, Da rauscht manch frischer Weisheitsquell wie aus Granites Spalten.

Tief wurzelt unter Stein und Moos der Eiche mächt'ger Schaft ; So gründen in der Vorzeit Schoss die Wurzeln unsrer Kraft.

Die Lehrerin der Könige, das ist die Weltgeschichte,

Sie lehrt, wie ein gerechter Gott die Gross' und Kleinen richte, Sie lehrt, wie in der Jahre Lauf das Nichtige vergeht, Sie lehrt, wie in der Zeiten Sturm das Tüchtige besteht.

Und hört er so der Ahnen Lob, da ahnt's dem alten Helden, Dass cinst auch seines Namens Ruhm die Sagenbücher melden Und Alcuin und Eginhard sie schreiben heimlich auf Des Kaisers schlichte Lebensart und grossen Heldenlauf.

Verwittert ist sein Heldenleib im Kaiserdom zu Aachen, Doch lebt sein grosser Name noch in aller Völker Sprachen, Doch lebt der alte Kaiser Karl in deutschen Lied und Wort, So lang' die deutsche Zunge klingt, bei seinen Deutschen fort.

Or these spirited lines by Kopisch on Bliicher :-

Die Heere blieben am Rheine stehn :

Soll man hinein nach Frankreich gehn?

Man dachte hin und wieder nach,

Allein der alte Blücher sprach :

"Generalkarte her!

Nach Frankreich gehn ist nicht so schwer.

Wo steht der Feind? "-Der Feind? dahier. 
"Den Finger drauf, den sclagen wir! Wo liegt Paris?"-Paris dahier!

"Den Finger drauf! das nehmen wir!

Nun schlagt die Brücken übern Rhein!

Ich denke, der Champagner-Wein

Wird, wo er wächst, am besten sein!

Vorwärts!"1

For the German teacher there is no lack of similar material. It is possible to present the whole pageant of German and Prussian history to the small boy through the medium of verse, and for the secondary stage there is seldom any difficulty in finding suitable lyrics to illustrate any episode. Much of it, it is true, does not rise above a certain level, but it is all of respectable merit, and makes the right appeal to boyish feelings.

The facilities of the teacher in England are not so great. If we place on one side historical plays and longer poetical works, the supply of lyrics and of short poems which form suitable units for a lesson or for committing to memory is limited. For some periods scarcely any illustrative verse of this kind is to be found. for others the stock is meagre or not suited to small boys. ${ }^{2}$

From the Roman occupation up to the Norman

1 A good compilation of German historical verse is Ausgerwählte Gedichte für den Geschichts-Unterricht (Dresden i 886).

2 Good compilations for reference are Poems of English History, by J. A. Nicklin ; Carmina Britanniae, by Miss C. L. Thomson; and English History in Verse, by E. Pertwee. The first is exclusive, and aims at giving nothing that is not of some value for its literary form; the second is fuller, and for the earlier years contains some excellent translations from the French ; the third contains selections from almost everything in rhyme that alludes to any historical topic. 
Conquest the only really suitable English poems by standard writers are Cowper's Boadicea, Longfellow's Othere's Voyage, and possibly Wordsworth's lines on Canute. From the Conquest up to 1399 the only poems by writers who are not at present living are Longfellow's Norman Baron, Gray's Bard, the Bannockburns of Scott and of Burns, and Sir F. T. Palgrave's Crecy. For the period 1399-1 588, Drayton's Agincourt, Scott's Flodden Field, Jane Elliott's Flowers of the Forest, Warner's Execution of Lady Jane Grey, and Wordsworth on Latimer and Ridley, nearly exhaust the list of standard poems. For the period I 558-17 I4 the supply is larger. Among other poems, Constable on the Death of Sir Philip Sidney, Edmund Spenser on Eliza, Queen of the Shepherds, Macaulay's Armada and Battle of Naseby, Milton on Fairfax, Marvell's Ode to the Lord Protector on his Return from Ireland, Milton on Cromwell, and Hawker's Song of the Western Men supply capital material, and there are also some good ballads, such as The Honour of Bristol. It is, however, plain that the list of first-rate poems is meagre, and that some of them, such as Gray's Bard and Milton's Sonnets, are not wholly suitable for the purpose with younger boys. They might profitably be taken in the literature lesson, but they are difficult if considered as "atmosphere" for a history lesson.

In this dearth it is evident that we cannot confine ourselves to lyrical poetry, but must press into our service suitable extracts from longer poems and from historical plays. It is equally evident that we must not be restricted to the use of poetry that is contemporary with the events. Ballads are to be found in fair number, but they are frequently of great length relatively to the 
amount of historical fact that they illustrate, and therefore must be used with moderation. Occasionally the political poems can be drawn upon, but even when modernised or translated they are suitable only for the higher of the stages that we are considering, and boys could not be asked to commit them to memory. ${ }^{1} \mathrm{We}$ must therefore be prepared to press into our service anything that seems suitable, no matter how recently it may have been written. One of the best imitations of an old ballad that has recently appeared deals with Perkin Warbeck, ${ }^{2}$ and is of value when dealing with a period for which interesting illustration is difficult to find. It has not yet found its way into the anthologies of historical verse, and a few stanzas will show its quality.

At Turney in Flanders was I born,

Fore-doomed to splendour and sorrow ;

For I was a king when they cut the corn, And they strangle me to-morrow.

Oh! why was I made so red and white, So fair and straight and tall?

And why were my eyes so blue and bright, And my hands so white and small?

I was nothing but a weaver's son, I was born in a weaver's bed;

My brothers toiled and my sisters spun, And my mother wove for our bread.

And all the path for "the Rose" to walk Was strewn with flowers and posies.

1 See The Political Songs of England, from the reign of John to that of Edward II., ed. and tr. by T. Wright, I839; and Political Poems and Songs, from the Accession of Edward III. to that of Richard II., ed. by T. Wright, 1859.

2 In The City of the Soul, Anon. I 899. 
I was the milk-white rose of York, The rose of all the roses.

And the Lady Margaret taught me well,

Till I spake without lisping

Of Warwick and Clarence and Isabel, And "my father" Edward the King.

And I sailed to Ireland and to France, And I sailed to fair Scotland, And had much honour and pleasaunce, And Katherine Gordon's hand.

I was not made for wars and strife And blood and slaughtering;

I was but a boy that loved his life, And I had not the heart of a king.

Oh! why hath God dealt so hardly with me,

That such a thing should be done,

That a boy should be born with a king's body

And the heart of a weaver's son?

They promised me a kingly part And a crown my head to deck, And I have gotten the hangman's cart And a hempen cord for my neck.

Oh ! I would that I had never been born To splendour and shame and sorrow, For it's ill riding to grim Tiborne, Where I must ride to-morrow.

I shall dress me all in silk and scarlet, And the hangman shall have my ring;

For though I be hanged like a low-born varlet, They shall know I was once a king.

And may I not fall faint or sick

Till I reach at length the goal;

And I pray that the rope may choke me quick, And Christ receive my soul. 
The vigour of this ballad is sufficient to rectify the aridity of the family tree of York and Lancaster, and to render less obnoxious a complete list of all the conceivable quarters from which competitors with Henry VII. might have arisen. Surely it would be a sorry pedantry that refused to employ it because it was not contemporary, and this criterion may therefore be placed on one side.

Our task is harder when we attempt to establish a standard of selection. For the lesson in English Literature it is comparatively simple to find one. No literature that is not of acknowledged excellence should be admitted, and although tastes differ, there is a considerable consensus of opinion as to the merits of standard verse. For the purpose of illustrating history we cannot aim so high without unduly restricting our field. Longfellow's Othere and Norman Baron are not fine poetry, but they serve a useful purpose with lower forms. The soliloquy placed by Mr. Alfred Austin in the mouth of King Alfred when, in retreat at Athelney, he muses over the map of England, does not, perhaps, present that writer at his best:-

Yes, thus I trace it, ocean-fashioned land And wrinkled by the waves, that rolling round

Its rough irregular shore, run out and in, Following it always as though loth to leave, Nay, eager, were they let, to find a way

To its very heart! England ! once Egbert's England, And his to be again, if Heaven but deign Use my poor brain and blade to wrench it back For Christ and Cerdic's race! Northumbria, Cradle and cloister of the learned Bede, My ne'er seen master! Rude East Anglia, Shouldering the ocean, as to push them off Who dare to come too close: twice sacred Kent, 
Whither came Caesar first, Augustine next, To win the isle to government and God!

Then my own Wessex woods and fastnesses, Creeks, bays, bluffs, combes, and shoreward setting streams, Crowned at their source with burgh and sanctuary, Now menaced by the Dane, and fenced in north By Burhed's Mercia, Burhed overcome, And feebly flying where he should have stood, And won, or died. For all of these were Egbert's. Aye, and the western shore's once glorious lord, Aldhelm's Geraint, owned Egbert overlord, Even to the uttermost point of land where sounds Nought save the billows shocking herbless crags, Or sea-gulls wheeling over wind-lashed waves.

yet there are few teachers who might not make use of its allusive nature to revise and expand previous knowledge. Assuredly we must not be too critical when we are on the search for instruments of this kind: even such a jingle as The Vicar of Bray is of value to bring home the changes in Church sentiment during several successive reigns, and may be tolerated just because it makes no claim to literary merit. The dividing line is, however, soon reached. On which side of it stands the following extract from Mary Tudor, by Sir Aubrey de Vere, describing the death-bed of Edward VI.?

Jane. O peace, good father, peace, the king sinks fast. Mary. Perils beset me-scorning all I come :

Shall I abide with thee?

Edw. 'This gentle Jane

Hath been a sister in my sister's absence.

Mary. Why was I bade to go? He bade me fly, Ah, traitor! (pointing to Northumberland).

Edw. It is now too late-too late!

I have done what it were well had ne'er been done. Jane. O would to God that act might be recalled! 
Mary. What act?

Jane.

That means me queen.

Mary.

Thou queen! O never

Shall regal crown clasp that unwrinkled brow!

Thou queen? go, girl-betake thee to thy mappets!

Call Ascham back-philosophise-but never

Presume to parley with grey counsellors,

Nor ride forth in the front of harnessed knights !

Leave that to me, the daughter of a king.

$E d w$. I have wronged thee to save the State from wrong.

I had much to say : but faltering thought and tongue

Forbid. Never shall foreign prince or prelate

Bear sway in England. So my father willed.

Cranmer, speak thou.

North.

Nay, I speak now. The king

Still, madam, proffers hope, on penitence.

The crown may yet be yours-this act annulled;

If here before this dying saint, in presence

Of this most holy prelate, and this lady,

Wise past her years, your errors you renounce.

Mary. Sir, have you done? simply I thus reply.

Not to drag England from this slough of treason-

Nor save this lady's head-nor yours, archbishop;-

Not even my brother's life-would I abjure

My faith, and forfeit heaven!

Cran. Pause, proud lady!

The end hath come. Lo, one among us stands,

Chainer of every tongue ! queller of princes!

One moment more, and penitence were vain.

\section{All kneel by the king's couch.}

$E d w$. Lord keep thy people steadfast in the faith! I die-bless all-Jesus receive my soul.

[Dies.

It is of undoubted value that the pupil should realise that the characters about whom he is hearing were brought into human relations with one another, but the reader must decide for himself what degree of historical 
impossibility counterbalances allusive value. In this case Mary was not at the death-bed of her brother, although after his death she was summoned to attend his dying moments. Northumberland's motives were obvious, and fortunately for her she discovered the ruse in time. Inaccuracy of fact, if not carried too far, is in itself no reason for discarding a poetic extract. Shakespeare's inaccuracies may often be used as a basis for profitable exercises. Let it be repeated that it is only the theorist in his study who is disposed to be hypercritical in this matter. The schoolmaster who has memories of days when either he or his class were tired or stupid is likely to welcome the introduction of any matter that may lessen the strain without diverting the attention of his pupils from their work; but the combination of improbabilities with mediocre workmanship to be found in the extract just quoted undoubtedly places it on the margin. This margin is easily crossed. It is surely unnecessary to analyse the reasons that make The Black Prince, by Menella Smedley, not wholly desirable :-

I'll tell you a tale of a knight, my boy,

The bravest that ever was known;

A lion he was in the fight, my boy,

A lamb when the battle was done.

Oh, he need not be named! for who has not heard

Of the glorious son of King Edward the Third?

Often he charged with spear and lance,

At the head of his valorous knights;

But the battle of Poictiers, won in France,

Was the noblest of all his fights;

And every British heart may be

Glad when it thinks of that victory.

The French were many, the English few,

But the Black Prince little heeded: 
His knights, he knew, were brave and true,

Their arms were all he needed;

He asked not how many might be the foe, Where are they? was all he sought to know.

or to make an inventory of the demerits of Joseph Anstice on The Death of Cour de Lion :-

One humble arm, one silent shaft could bring

Fate's awful summons on its noiseless wing.

Yet though the clarion spoke not, though the sound

Of festal triumph scarce was heard around,

In that dark hour a purer bliss was given,

And peaceful seraphs hymned their joy in heaven,

When on thy lips their own compassion hung,

And mercy trembled on thy faltering tongue;

In thy last breath, forgiveness' voice was heard,

And life's last conquest crowned thy latest word.

or of the following lines on The Signing of Magna Carta:-

Green meadow by the Thames-fair Runnymede,

Where tyranny received its fateful blow,

Thy name shall live while centuries come and go-

Crowned with the flowers that blossom from thy seed.

In vain thy wrath, oh king! All impotent, Thy frenzied rage doth sink in terror now;

The sign of fear is on thy pallid brow,

Wild, haggard eyes are on the Charter bent.

The pen is thrust within that shaking hand;

And now his name doth ratify the scroll,

The which doth give while ages onward roll,

The boon of liberty to bless our land!

or of $A$ Call on Sir Walter Raleigh, by Sarah Platt :-

The knaves speak not the truth, I see

Sir Walter at the window there

- That is the hat and sword, which he

In pictures hath been pleased to wear. 
There stands the very cloak whereon

Elizabeth set foot. (But oh,

Young diplomat, as things have gone

Pity it is she soiled it so !)

And there-but look, he's lost in smoke (That weirdly charmed Virginia weed);

Make haste, bring anything; his cloakThey save him with a shower, indeed. ${ }^{1}$

There is, then, a limit beyond which it is undesirable to go in the search for illustrative poetry, and we must be careful not to transcend it, hard-pressed though we may be in the search for allusive verse.

It is refreshing to turn from poems like these to some of the excellent verse dealing with historical incidents that has been contributed by recent writers. Poems such as Mr. Dobson's Armada and Mr. Newbolt's Drake's Drum supply capital material. Indeed, for the seafaring life of the Elizabethan Age, verse can be found for two distinct stages of schoolboy life. In the earlier stage the two poems just mentioned and Macaulay's Armada can be read; in the later stage stirring passages can be taken from Mr. Swinburne's Armada:-

The wings of the south-west wind are widened; the breath of his fervent lips,

More keen than a sword's edge, fiercer than fire, falls full on the plunging ships-

1 The last four extracts are quoted from E. Pertwee's English History in Verse. As far as these particular poems are concerned, it is not easy to agree with Mr. A. T. Pollard, who contributes a preface, that they are good channels through which to approach "the Glories of our National Inheritance from the human, imaginative, and sympathetic point of view." Neither is this, to quote the same writer, the right way "to dissipate the notion that history is a dry study." 
The pilot is he of their northward flight, their stay and their steersman he;

A helmsman clothed with the tempest, and girdled with strength to constrain the sea.

And the host of them trembles and quails, caught fast in his hand as a bird in the toils;

For the wrath and the joy that fulfil him are mightier than man's whom he slays and spoils.

And vainly with heart divided in sunder, and labour of wavering will,

The lord of their host takes counsel with hope if haply their star shine still,

If haply some light be left them of chance to renew and redeem the fray;

But the will of the black south-wester is lord of the councils of war to-day.

One only spirit it quells not, a splendour undarkened of chance or time;

Be the praise of Oquendo for ever, a name as a star sublime.

But here what aid in a hero's heart, what help in his hand may be?

For ever the dark sea whitens and blackens the hollows and heights of the sea,

And galley by galley, divided and desolate, founders; and none takes heed,

Nor foe nor friend, if they perish; forlorn, cast off in their uttermost need,

They sink in the whelm of the waters, as pebbles by children from shoreward hurled,

In the North Sea's waters that end not, nor know they a bourn but the bourn of the world. 1

What boys would not be stirred by these lines, or by the following extract from Mr. Noyes's Drake, describing the seaman on the eve of his voyage?

And on that night, while Drake

Close in his London lodging lay concealed,

1 Swinburne, The Armada, vi. iii. 
Until he knew if it were peace or war With Spain (for he had struck on the high seas At Spain; and well he knew if it were peace His blood would be made witness to that bond, And he must die a pirate's death or fly

Westwards once more), there all alone he pored By a struggling rushlight o'er a well-thumbed chart Of magic islands in the enchanted seas, Dreaming, as boys and poets only dream With those that see God's wonders in the deep, Perilous visions of those palmy keys, Cocoa-nut islands, parrot-haunted woods, Crisp coral reefs and blue shark-finned lagoons Fringed with the creaming foam, mile upon mile Of mystery. Dream after dream went by, Colouring the brown air of that London night With many a mad miraculous romance. ${ }^{1}$

Or by the description of the Golden Hynde in the Pacific ?-

Now like the soul of Ophir on the sea

Glittered the Golden Hynde, and all her heart

Turned home to England. As a child that finds

A ruby ring upon the highway, straight

Homeward desires to run with it, so she

Yearned for her home and country. Yet the world

Was all in arms behind her. Fleet on fleet

Awaited her return. Along the coast

The very churches melted down their chimes

And cast them into cannon. To the south

A thousand cannon watched Magellan's strait, And fleets were scouring all the sea like hounds With orders that where'er they came on Drake, Although he were the Dragon of their dreams, They should outblast his thunders and convey, Dead or alive, his body back to Spain. ${ }^{2}$

1 Drake: An English Epic, by Alfred Noyes, Bk. i. 2 Ibid. Bk. vi. 
With boys at the highest of the stages that we are considering there are a number of historical plays by modern writers which can be read with advantage for the portrayal of character that they contain. The text-book speaks of "Babington's plot," but makes no suggestion that Babington may have been a man with high ideals and possessed of a rare quality of devotion. Here the historical play acts as a corrective, as in the following extract from Swinburne's Mary Stuart:-

Babington. Welcome, good friends, and welcomethis good day That casts out hope and brings in certainty

To turn our spring to summer. Now not long

The flower that crowns the front of all our faiths

Shall bleach to death in prison; now the trust

That took the night with fire as with a star

Grows red and broad as sunrise in our sight

Who held it dear and desperate once, now sure, But not more dear, being surer. ${ }^{1}$

Time forbids to give more than a few extracts from such plays during the history hour, but there are other methods. In boarding-schools it is an easy matter to organise parties for rapid reading out of school ; in dayschools the difficulties are greater but not insuperable. Swinburne's Bothwell, Tennyson's Becket and Mary Tudor, and, with older boys, Browning's Strafford can be read in this way.

The method of using shorter poems, when once selected, must largely be left to the teacher. They may simply be read with little exposition, or they may be used for revision purposes when they lend themselves to this procedure. Mr. Dobson's $A$ Ballad of the Armada affords a good illustration of this :-

1 Swinburne, Mary Stuart, Act I. Sc. i. 
King Philip had vaunted his claims;

He had sworn for a year he would sack us;

With an army of heathenish names

He was coming to faggot and stack us;

Like the thieves of the sea he would track us,

And shatter our ships on the main;

But we had bold Neptune to back us-

And where are the galleons of Spain ?

His carackes were christened of dames,

To the kirtles whereof he would tack us;

With his saints and his gilded stern-frames

He had thought like an egg-shell to crack us :

Now Howard may get to his Flaccus,

And Drake to his Devon again,

And Hawkins bowl rubbers to Bacchus-

For where are the galleons of Spain?

Let his Majesty hang to St. James

The axe that he whetted to hack us;

$\mathrm{He}$ must play at some lustier games

Or at sea he can hope to out-thwack us ;

To his mines of Peru he would pack us

To tug at his bullet and chain;

Alas that his Greatness should lack us.

But where are the galleons of Spain?

\section{Envoy}

Gloriana-the Don may attack us

Whenever his stomach be fain;

He must reach us before he can rack us-

And where are the galleons of Spain?

King Philip had vaunted his claims. What claims were these? He had sworn for a year he would sack us. Had he sworn for a year only? For how many years had he actually sworn? With an army of heathenish names. The class will be quite ready to retail to you some names of Spanish ships and commanders, if these 
have been given to them. Like the thieves of the sea he would track us. Had the English commanders been guilty of piracy or not? The points may here be revised. But we had bold Neptune to back usAnd where are the galleons of Spain? Where indeed? Let a boy go up to the map and find the coasts and the rocks upon which they had foundered. The whole of the poem abounds in similar opportunities, which can be used to the utmost, or only partially, as time permits.

There is perhaps a danger that with stupid pupils who have not properly mastered the facts which such poems are intended to illuminate, odds and ends of imagery or of expression may stick in their minds and completely distort any conception of the historical fact that may be there. This is well illustrated in the case of the astonishing answer given by Muriel Howard (p. 109): "The Spanish Armada was a fleet of ships which set out for a sail on the water. The day was nice, fine, clear, and the water was calm and everything the sailors wanted." This can be derived from no source other than the opening lines of Macaulay's Armada :-

It was about the lovely close of a warm summer's day, There came a gallant merchant-ship full sail to Plymouth Bay.

The danger is, however, not a serious one if the teaching be of even moderate competency. In the hands of an inefficient craftsman the best instruments are of little use.

For the history of the nineteenth century a useful selection can be made from Tennyson's poems. The lines on Buonaparte, the Ode on the Death of the Duke of Wellington, the stanzas on The Third of February 1852, 
The Charge of the Light Brigade and The Charge of the Heavy Brigade, A Welcome to Alexandra (1863), The Defence of Lucknow, the lines written To the Marquis of Dufferin and Ava, and on The Jubilee of Queen Victoria, all illustrate historical events in an interesting manner, while the Ode for the Opening of the International Ex hibition, the stanzas on The Fleet, and the lines on Politics would afford occasion for valuable discussions upon social progress, national defence, and the cleavage of political parties; but it is perhaps too much to hope that our examination-ridden schools will find time to consider topics of such importance.

In this sketch of the opportunities for using English verse in connexion with the history lesson attention has designedly been given to short poems, lyrics, or extracts from larger works that admit of separation from their context. Naturally it is not intended that longer works which deal with historical events or illustrate the social life of a period should be neglected; but their treatment must be different. They are in many cases too important merely to be introduced into the history lesson for illustrative purposes, and should therefore be read in the hours devoted to English Literature and correlated with the English History. Piers Plowman's Vision and Chaucer's Prologue to the Canterbury Tales may be read in a modernised form in connexion with the fourteenth century, and an attempt should be made to give boys some knowledge of the contents of all Shakespeare's English Historical plays, of which an inexpensive edition can be procured, ${ }^{1}$ while one or two of them can be read carefully during the year. With

1 Histories, Poems, and Sonnets of Shakespeare in Everyman's Library. 
certain boys such a play as Marlowe's Edward II. might be read out of school as already suggested. Equally important is the correlation of English prose literature with the history period; but this topic lies outside the scope of the present chapter.

There is yet another manner in which verse of the "ballad" class may be utilised. It is a profitable exercise to compare the account of an incident given in a ballad with those presented more soberly in prose chronicles. The following extracts will illustrate this :-

As itt beffell in m(i)dsumer-time,

When burds singe sweetlye on euery tree,

Our noble king, King Henery the Eighth,

Ouer the riuer of Thames past hee.

Hee was no sooner ouer the riuer,

Downe in a fforrest to take the ayre,

But eighty merchants of London cittye

Came kneeling before King Henery there. . . .

"To Ffrance nor Fflanders dare we nott passe,

Nor Burdeaux voyage wee dare not ffare,

And all ffor a ffalse robber that lyes on the seas,

And robb(s) vs of our merchants-ware." . . .

"He is a proud Scott that will robb vs all

If wee were twenty shipps and hee but one."

The king looket ouer his left shoulder,

Amongst his lords and barrons soe ffree :

"Haue I neuer lord in all my realme

Will ffeitch yond traitor vnto mee?"

"Yes, that dare I!" sayes my lord Chareles Howard,

Neere to the king wheras hee did stand;

"If that Your Grace will give me leaue,

My selfe wilbe the only man." 
"Thou shalt haue six hundred men," saith our king,

"And chuse them" out of my realme soe ffree;

Besids marriners and boyes,

To guide the great shipp on the sea." ...

With pikes, and gunnes, and bowemen bold,

This noble Howard is gone to the sea

On the day before midsummer-euen,

And out att Thames mouth sayled they. ...

Then follows a description of Andrew Barton :-

"Hee is brasse within, and steele without, And beames hee beares in his topcastle stronge;

His shipp hath ordinance cleane round about ; Besids, my lord, hee is verry well mand.

" He hath a pinnace, is deerlye dight, Saint Andrews crosse, that is his guide;

His pinnace beares nine score men and more, Besids fifteen cannons on euery side." . . .

"Now by my ffaith," sais Charles, my lord Haward, "Then yonder Scott is a worthye wight."

"Take in your ancyents and your standards, Yea that no man shall them see, And put me fforth a white willow wand, As merchants vse to sayle the sea."

But they stirred neither top nor mast But Sir Andrew they passed by :

"Whatt English are yonder," said Sir Andrew, "That can so little curtesye?

"I haue beene admirall ouer the sea More than these yeeres three;

There is neuer an English dog, nor Portingall, Can passe this way without leaue of mee. 
"But now yonder pedlers, they are past, Which is no little greffe to me :

Ffeich them backe," sayes Sir Andrew Bartton, "They shall all hang att my maine-mast tree."

With that the pinnace itt shott of, That ny Lord Haward might itt well ken; Itt stroke downe my lords fforemast, And killed fourteen of my lord his men. ...

But att Sir Andrew hee shott then;

Hee made sure to hitt his marke;

Vnder the spole of his right arme

Hee smote Sir Andrew quite throw the hart.

Yett ffrom the tree he wold not start, But he clinged to itt with might and maine;

Vnder the coller then of his iacke, He stroke Sir Andrew thorrow the braine.

"Ffight on, my men," sayes Sir Andrew Bartton, "I am hurt, but I am not slaine:

I'le lay mee downe and bleed a-while, And then I'le rise and ffight againe.

Ffight on, my men," sayes Sir Andrew Bartton, "These English Doggs they bite soe lowe;

Ffight on ffor Scotland and Saint Andrew Till you heare my whistle blowe!"

But when the $[y]$ cold not heare his whistle blowe, Sayes Harry Hunt, I'le lay my head You may bord yonder noble shipp, my lord, For I know Sir Andrew hee is dead.

With that they borded this noble shipp, Soe did they itt with might and maine:

The ffound eighteen score Scotts aliue, Besids the rest were maimed and slaine. 
My lord Haward tooke a sword in his hand, And smote of Sir Andrews head;

The Scotts stood by did weepe and mourne,

But neuer a word durst speake or say. . . .

With his head they sayled into England againe,

With right good will, and fforce and main,

And the day beffore Newyeeres euen,

Into Thames mouth they came againe. . . .

Several contemporary chronicles record the same event.

I. Hall's Chronicle, I 548.-In June (I 5 I I), the king being at Leicester, tidings were brought to him that Andrew Barton, a Scottish man and a pirate of the sea, saying that the king of Scots had war with the Portingales, did rob every nation, and so stopped the king's streams that no merchants almost could pass, and when he took the Englishmen's goods, he said they were Portingales' goods, and thus he haunted and robbed at every haven's mouth. The king, moved greatly with this crafty pirate, sent Sir Edmund Howard, Lord Admiral of England, and Lord Thomas Howard, son and heir to the Earl of Surrey, in all the haste to the sea, which hastily made ready two ships, and without any more abode took the sea, and by chance of weather were severed. The Lord Howard, lying in the Downs, perceived where Andrew was making toward Scotland, and so fast the said lord chased him that he overtook him, and there was a sore battle. The Englishmen were fierce, and the Scots defended them manfully, and ever Andrew blew his whistle to encourage his men, yet for all that, the Lord Howard and his men, by clean strength, entered the main deck; then the Englishmen entered on all sides, and the Scots fought sore on the hatches, but in conclusion Andrew was taken, which was so sore wounded that he died there; then all the remnant of the Scots were taken, with their ship called The Lion. All this while was the Lord Admiral in chase of the bark of Scotland called Jenny Pirwyn, which was wont to sail with The Lion in company, and ... he laid him on board and fiercely assailed him, and the Scots, as hardy 
and well-stomached men, them defended; but the Lord Admiral so encouraged his men that they entered the bark and slew many, and took all the other. Then were these two ships taken, and brought to Blackwall the second day of August, and all the Scots were sent to the Bishop's place of York, and there remained, at the king's charge, till other direction was taken for them. . . .

II. Bishop Lesley, writing some years later, openly accuses the English of fraud. "In the month of June," he says, "Andrew Barton, being on the sea in warfare contrar the Portingals, against whom he had a letter of mark, Sir Edmund Howard, Lord Admiral of England, and Lord Thomas Howard, son and heir to the Earl of Surrey, past forth at the king of England's command, with certain of his best ships; and the said Andrew, being in his voyage sailing toward Scotland, having only but one ship and a bark, they set upon at the Downs, and at the first entry did make sign unto them that there was friendship standing betwix the two realms, and therefore thought them to be friends; wherewith they, nothing moved, did cruelly invade, and he manfully and courageously defended, where there was many slain, and Andrew himself sore wounded, that he died shortly; and his ship, called The Lion, and the bark, called Jenny Pirroyne, which, with the Scots men that was living, were had to London, and kept there as prisoners in the Bishop of York's house, and after was sent home in Scotland."

Here the class may be expected to note the discrepancies between the ballad and the prose accounts, and may be shown that the ballad, apart from its added colour and dramatic effect, illustrates the importance of the London trade with Flanders and Bordeaux. ${ }^{1}$ The exercise might well introduce a useful discussion of evidences.

1 This illustration is borrowed from Studies in Historical Method, by M. S. Barnes (1897), a work that can strongly be recommended. 


\section{CHAPTER X}

SOME PROBLEMS AND DEVICES OF CLASS-ROOM PRACTICE

SHOULD the atmosphere of the history hour be a modern one or should it be redolent of the period that is being taught? Opinions differ. " All history teaching," say some, "should begin and end with the policeman." That is to say, an aspect of present-day society is to be the starting-point, and the object of the history lesson is to explain how it came into existence, to elucidate its historical meaning. The policeman is to lead on to a realisation of the stages by which the modern fabric of law and order has been built up; throughout the history lesson the pupil is to be in the twentieth century. On the other side it is asserted with equal force that the object of the history lesson is to get the pupil's ideas out of their modern groove and to induce him to consider facts of a certain kind in a new setting, that he should be soaked in the century concerned until he seems to live in it ; in short, that the intrusion of modern life into the hour devoted to the fifteenth century is as objectionable as the employment of English during a French lesson. Here the Aristotelian doctrine of "the mean" does not help us. Teaching frequently has to be con- 
ducted by exaggeration. The middle ages will not be appreciated by pupils unless their peculiar atmosphere has been given by every device in the teacher's power, nor will the modern reference of history be realised by them unless they are made to transfer the circumstances in thought to the present day. In this case success in teaching is reached not by holding to the mean but by oscillating between extremes.

It is well to make boys realise in terms of fifteenth century life that the mediæval Londoner liked a strong king because for him he meant material well-being and commercial stability; but it is equally necessary to bring home to them that the same factors are at work nowadays, and that the mechanism of stability has been built up by a long series of protests and demands on the part of traders. "Jones, what did you have for dinner yesterday ?" A list of comestibles is extracted from the unwilling Jones, and may be black-boarded : mutton, rice pudding, bread, sugar. Which of these are produced in this country? Only the mutton and the bread. But the mutton may have come from New Zealand, and the bread must have in it at least a proportion of "Manitoba No. I. hard" or it would not suit the public taste. What would happen to Jones's dinner in time of war or if, in time of peace, our navy were insufficient to ensure the safety of merchant vessels ? The price of all these commodities would rise on account of the risk and occasional loss of cargoes. In consequence Jones would have had either a smaller dinner or one of inferior quality. How about the tradesmen who sell these goods? It is easy to show that the increase in retail price would not make up to them for the lack of stability and security, and that if any government seriously 
endangered these it would not remain long in power. Again, London in the fifteenth century is in danger of being occupied and sacked by a victorious army. It is easy to show that if such a danger threatened London at the present day, Jones's merchant father might lose his income. In all such instances it is possible by a skilful alternation to keep the pupil in the century at which he is working without allowing him to forget that his own century presents similar situations.

When introducing a class to the conditions of evidence it is frequently desirable to start with a modern instance. "Who saw the South African football match on Saturday?" A few boys plead guilty. Who did not see it but heard of it from an eye-witness? Who did not see it but read of it in the papers? Which of the boys who were at the match were close by when there was that dispute, and what opinions did they form as to the rights of the matter? None of them were close by ; but although they could not see it plainly they have all formed definite though diverse views. Here we have a number of the factors to be considered in estimating evidence. Which boys are likely to have the most accurate knowledge of the match ? It will be suggested that the eye-witnesses have the most trustworthy information, and for the present this answer may be taken. But are the eye-witnesses, likely to have a knowledge of the whole match? No, because it is impossible from any one spot to see with clearness what takes place all over the field ; indeed, it is evident in the present instance that the eye-witnesses do not agree. Here, then, is one source of error. The eye-witness may not have seen correctly, or may have misinterpreted what he actually saw. The additional sources of error involved in the 
other modes of obtaining information about the match may now be considered. The boys who heard of the match from an eye-witness have no guarantee that he reported with accuracy what he saw, those who read of it in the paper cannot be sure that the reporter did not make mistakes when writing down his impressions from memory. So that in the case of second-hand knowledge we have as possible sources of error, (I) Errors of observation; (2) Errors of inference from facts observed; (3) Errors of reporting caused by either inaccurate memory or carelessness, or both. We may now proceed to ask from what sources the historian of football in England twenty years hence would get his information about this particular match, and conclude that he would consult the newspapers or any other written accounts that he could find. With any luck the teacher may find that the rival local papers have given slightly discrepant accounts of the match. What will our imaginary historian do in this case? He will have to reconcile the two accounts or find a third account to check them by. Possibly he might try to find some one living who actually saw and took notes of the match. After an introduction of this kind boys will be far readier than before to appreciate the question of evidence when it arises in connexion with a document.

Allusion has already been made (pp. 134-5) to the boy's notebook, and it has been suggested that on one page may be placed a line of time and on the opposite page facts and illustrations that are not to be found in the text-book. If this suggestion were uniformly adopted, it is evident that the pupil would at school obtain no practice in taking notes freely. How far is it advisable that he should do so? To this as to so 
many other questions about teaching it is difficult to give an answer in general terms. It is undoubtedly of the greatest importance that boys should leave school able to listen to a discourse or take part in a discussion, and at the same time to get down a few notes which represent the pith of what they have heard. To learn to do this is a good mental training in itself, and the inability to take' such notes is a serious disadvantage where University work is concerned. On the other hand, many boys find it difficult at once to listen and to select matter for notes, and with certain classes the result of "free" note-taking is that the boy's notebook contains a page of illegible and badly selected notes very ill-fitted for purposes of revision, while he may remember little or nothing of the rest of the lesson. It is not uncommon to find boys of fourteen who are so stupid or have been so ill-trained that they find it difficult to copy accurately into their notebooks what has been written on the black-board. For these, and in most cases for middle-form boys, it is necessary that some notes should be dictated if the boy's notebook is to supplement the text-book as a means of revision. A middle course can be taken. The upper half of the page can be reserved for dictated notes, leaving the lower half for free notes. These the boy need not be compelled to take, but he may be encouraged to do so, and when the notebooks are inspected, additional marks can be given if the free notes have been well taken. The boy's notebook will then present the following appearance :- 


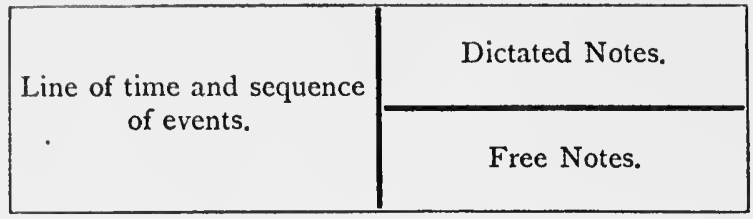

If this device is adopted it is possible to introduce a small amount of free note-taking at an early stage, and the quantity can be increased in the higher forms.

By the time that a class can be trusted to take notes freely without much or any supervision, they are reaching the highest of the stages considered in the foregoing chapters, and a slight change of method is becoming desirable. The class-room library has not been neglected, and it will now begin to supplement the source-book and the text-book to a greater degree than formerly. In few boys' schools are class-room libraries to be found; yet if good teaching is to be synonymous with good learning their presence is highly desirable for modern subjects, such as English history, English literature and geography, and now that books have been cheapened there is no longer any excuse for failing to provide them. Certainly in schools which are subsidised by the State and the rate-payer, it should be realised that the subsidy may be wasted for the lack of a small additional expenditure on class-room libraries. The school library, no matter how well equipped, is no substitute for the class-room library, as it is not under the teacher's eye, and he has no opportunity, with the limited time at his disposal, of assuring himself that the boys take out the volumes that they are asked to read. When the books are in the class-room, it is far easier to control their use, and in addition they may be consulted during the lesson. 
It is difficult to lay down rules for the formation of such libraries, as the details of their composition must depend largely on the period studied and the resources at the disposal of the school, but a few principles are worthy of consideration. There should be more than one copy even of the larger works, while of smaller books four or five copies are desirable. For the Elizabethan period, with a class of boys using the threevolume Gardiner, the following list would form a good nucleus : Froude's History of England, vols. vi.-xiii.; Lingard's History of England, vol. vi. ; A. F. Pollard's Political History of England, I547-1603; Creighton's Elizabeth; Martin Hume's Burleigh; Corbett's Drake and the Tudor Navy; Traill's Social England, vol. iii.; A. F. Pollard's Tudor Tracts; G. W. Prothero's Select Statutes; Hakluyt's Voyages. It would be easy to add to the number, but the fear is that to provide several copies even of these will be considered too great a tax on the school finances. Here we can only repeat what has already been said of volumes of extracts from contemporary authorities, that if such essential apparatus is not provided the teacher may give the most admirable lessons, but the class will be given no opportunity of reading history written with atmosphere, of making an abstract from an account longer even than that of a large text-book, and of comparing the different views taken by various writers of the same episode or personality. When the conditions are so adverse it may be doubted if it is worth while for upper forms to devote much time to the subject.

When the necessary books have been supplied it is easy to make the class contribute largely to the lesson. There are frequently five or six boys willing to take a 
considerable amount of trouble and to read for themselves out of school. With a little guidance these will be prepared to produce in class the differing views on an episode in the Reformation taken by a Protestant and a Catholic historian respectively, or to discuss from the standpoints of the authors they have consulted the characters of the leading personages of the period. It is often a useful exercise to plan out beforehand with the class the leading features of the next lesson, and to ask each boy or group of boys to be ready to supply special information on definite topics, giving them references to the books available. It is true that much work of this kind is beyond the scope of middle-school boys, and that its treatment therefore lies outside the scope of this book, but even in a middle class some good work may be done with the aid of a group of clever boys. In addition, class-room debates on stock subjects such as the execution of Mary Queen of Scots are greatly facilitated by access to books of reference. Even if, through lack of time, it is difficult to make much use of these larger works, their presence is none the less desirable, as the class which sees them daily on the book-shelves can scarcely fail to realise that they are there to be consulted. Without some such experience the majority of boys in a secondary school may well go through life without seeing even the outsides of the greater treatises, while to have read an author's name on the binding is often the first step towards reading his works.

It remains to mention two series of volumes which are of the greatest value in every period both for purposes of "local history" and for small detail : the Historic Towns series, edited by the late Professor 
Freeman, and Besant's Survey of London. These should not be omitted in the composition of our library. For the understanding of English mediæval history a knowledge of the topography of medirval London cannot be overrated, and this can be obtained in a most interesting manner from the maps to be found in the Survey. One, at least, of these, Wyngaerde's Panorama of London in 1543, can be obtained separately, ${ }^{1}$ and should be placed on the walls of the class-room, since it gives in a very concrete form a bird's-eye view of London, showing clearly the city walls and gates, the Tower, the Steelyard, the Abbey, Westminster Hall, the mansions of historic personages, and many other elements of detail. In no other way is it so easy to give boys a sense of familiarity with the spots where so many scenes of English history were enacted.

1 Panorama of London, Westminster, and Southwark as they appeared A.D. 1543, from a drawing by Anty van den Wyngaerde. Sutherland Collection. Bodleian Library (A. \& C. Black, price Is.). 


\section{CHAPTER XI}

\section{THE TEACHER OF HISTORY}

PERHAPS it is not fair to blame a nation which values material prosperity highly if in its organisation of education it lays the greatest stress on the material side. Money is generally forthcoming for school-buildings, care is frequently lavished on dietary, while to the teacher are devoted only the money and the care that happen to remain over. As a natural consequence of this, both the salaries and the social standing of teachers have tended to be lower than in the case of other professions ; as a further consequence teaching has frequently been ill carried out, and, as inevitably, a great scepticism of and dislike for education has filled the British mind. This scepticism has often been justified. A British parent in business knows that his son's teacher is in receipt of a low salary, that his prospects are poor, and the security of his position small; he argues, not without reason, that in an expanding Empire the opportunities of earning a livelihood are so numerous that able men of spirit will not for long remain in a pursuit which offers so few material attractions. Although prepared to grant that some men will teach because they are interested in education and wish in this way to 
devote themselves to social service, he will argue that the State cannot count on manning one of its services solely by enthusiastic volunteers; indeed, he may point out that even in the Church, which is supposed to appeal to motives of a special kind, the quality of the worker has tended to deteriorate as the value of tithe has fallen. Consequently, although he has no very definite ideas as to the right qualifications of a teacher, he continues to be sceptical and to grudge the money that he is forced to contribute towards what he is apt to regard as an organised fraud. He therefore welcomes the more material element in the organisation, the army of inspectors, the array of scheduled reports, as apparent checks upon inefficiency in teaching. And yet it should be evident that before teaching can be organised and pressed into shape it must be there to organise, that before ill-regulated teaching-power can be disciplined into form by an external agency it must be there to discipline, that before the enthusiasm of the specialist can be curbed and brought into line with practical exigencies it must be there to curb. No organisation, no inspection, no repressive force can be productive of good unless it has as material to work upon, and indeed finds opposed to it, a vital force which we may call teaching-insight, which will react against the efforts made to repress it and will gain strength through this reaction, which can be guided into sound channels and may be pruned and clipped with advantage, but which never can be produced by organisation from without.

This tendency of the community to lay stress upon the mechanical side of education at the expense of the spiritual element is perhaps easier to justify for the traditional subjects of instruction than for those recently 
irrtroduced. In the early stages of Latin teaching, as Latin teaching used to be conceived, much of the work is of a mechanical nature. Paradigms have to be learned and rules applied, and while an underpaid drudge will not do good work, he may lay a fair mechanical basis for what is to follow. Similarly in the early stages of mathematical teaching, although a teacher who has no insight, and who teaches only because his abilities will not permit him to earn a scanty living in any other pursuit, will waste much of his pupils' time, he will none the less drill them in certain processes and formulae which are not without value.

When we turn to historical and literary subjects the case is different. It is in connexion with these as opposed to pure linguistic that teachers are now for the first time compelled to face real educational issues. With history, as with any other subject in which ideas rather than symbolism and formulae are the chief element, the teacher's qualities and equipment are of the first importance. Unless he possesses insight it may be as misleading to estimate the progress of education by the number of schools and of inspectors as it would be to gauge the religious feeling of a community by the number of persons who pay pew rents. In historyteaching the teacher is introducing his pupils not to linguistic symbols or to conventional knowledge, but to ideas which really matter; the exact method of presenting these ideas and the exact process that the pupil is induced to perform upon them are of real importance; there is no element that can be given stupidly without immediate and permanent loss; there is no conception which may not be degraded if the imparting of it is entrusted to men whose grip of social factors is weak and 
whose occupations out of school are trivial; there is no room for the dull performance of hodman's work. The subject-matter of the teaching is human character and social progress; as surely as the handling of it is good it will produce in the rising generation an intensification of social thought, as surely as it lacks inspiration it will tend to the deadening of such thought. With a subjectmatter of this kind there is no middle way, and thus history-teaching requires in a marked degree the qualities which are found in all good teachers, and which can be dispensed with only when the matter of the subjects taught is conventional and unreal, standing in no close relationship to human life.

What particular body of knowledge and what historical training is needed as well? Is it, for example, essential that all history-teaching in middle forms should be given by specialists in history who teach little or nothing else, and who may therefore teach it to sets and not to forms? This question does not concern history alone. The demand that subjects shall be taught properly produces an answering demand for specialists. Geography, taught on scientific lines, is asked for. "We must get a specialist in geography," say the school authorities. Similar pressure produces a demand for a history specialist, and soon a specialist in English literature will be asked for. As result the school tends to be converted into a system of set masters, each teaching his special subject, and the old "form " system, under which each master taught a good many subjects to the same boys and saw a good deal of them, tends to disappear. It may be asked if this tendency would not be a calamity if allowed to go to extremes. To teach sets only and to be confined to one subject is 
probably narrowing to the teacher, and it also deprives the boy of that constant intercourse with one master which has often been productive of good, and which is especially valuable when a subject whose content may be of so intimate a nature as that of history is in question. In addition it is only with the form-master system that the unpremeditated and internal correlation of subjects can be carried out. The solution of the difficulty is a compromise which lays more or less stress on the grouping of a certain number of subjects under one teacher, and it may be hoped that this compromise will approximate as far as possible to the formmaster system. Naturally it would not be suggested that the same teacher should teach literary and mathematical subjects unless the conditions were exceptional, but there is no reason why with middle forms the same teacher should not teach history, geography, and English literature, or that a classic should not, in addition to some classics, teach history and English literature.

Neither is there any reason why a man who has had a rigorous training in the classics should not take up history and teach it even though it is not one of his degree subjects. If it is urged that after his professional duties are over he has no time or energy to break fresh ground, this can be only because he is overworked, and the sooner such conditions of work are altered the better. It must be recognised that a system, which leaves assistant masters no time for self-culture, tends in the long run to waste the money of the tax-payers. It is impossible for teaching to remain efficient unless teachers have some leisure and the will to use it rightly. ${ }^{1}$

1 It is also in place to note that one function of a course of professional training for teaching should be to introduce a 
Therefore, although it is desirable to have at a school some specialists in history, ${ }^{1}$ it is not essential for good teaching that the teacher must necessarily have specialised in history to the exclusion of other interests In any case the specialist will have to re-read his subject from the standpoint of school needs before he can teach it, and it is frequently an assistance to teaching if a competent man gets up a subject while engaged in school practice, as in these conditions the salient points and the elements of interest do not escape him.

Our history teacher, then, besides a good knowledge of his subject, must have a suitable personality and a thoughtful outlook upon life, but this does not complete his equipment. He also needs a grip of method so that his practice may exhibit the utmost spontaneity working in connexion with a clearly planned mechanism. Such method is an addition to personality, and cannot fitly be contrasted with it, although this contrast is sometimes made by those who maintain that the teacher is of more value than the method, and the personality than the manner of teaching. The personality that admits of this contrast may be little more than characteristics of manner or the freshness and breeziness of youth, excellent qualities, no doubt, but not to be counted on as a possession for life, while the method that admits of this contrast can be little more than a lifeless mechanism, a dull arrangement or rearrangement of subject-matter.

True personality involves elements of self-control, specialist in one subject to the literature and the methods of the other subjects which work in with his own to make a suitable group for school purposes.

1 The great increase in the number of graduates in history should make these easy to procure. 
while true method involves that control of subjectmatter which increases its meaning by giving it a new form. This control of ideas is not found without personality, and such a personality is not found without the control which renders method possible; it is, indeed, increased by the constant effort to manipulate and present ideas so that the meaning which they convey shall be convincing and suggestive. There need be no fear that method of this kind will lead to rigidity. Method is more than a self-imposed mode of action; it involves a daily revision, justification, and reimposition of the mode. In this it must be contrasted with mechanism which tends to be invariable, or is reconstructed only when its rigidity has led to disaster. Method, while it works on a basis of small elements of mechanism, combines and recombines them to suit the exigencies of the moment. Far from destroying initiative it actually fosters it. It is characteristic of mind that when it arranges restrictions for itself it tends to increase its own energy. The poet loves to arrange for himself an elaborate form of metre, and by his spontaneity rises superior to the self-imposed limitation,

In truth the prison unto which we doom Ourselves, no prison is.

and self-imposed form of this kind, which feeds the spontaneity that is to struggle against it, is the mark and the instrument of the good teacher.

Method is not acquired in a day, and from the beginner in history-teaching comparatively little can be demanded. Straightforward exposition and examination is frequently all that he is capable of, and the attempt to do more may distract his attention from the class. His mind should 
be stored with a knowledge of the possible varieties of method, but in the beginning he will do well to draw on his storehouse but little. It is when the first novelty of teaching has worn off that the necessity for method makes itself apparent. Teaching is a nerve-consuming process; vitality of nerve soon fails, and if vitality of spirit is not cultivated, dullness and inefficiency are the result. For the teacher who has thoroughly settled down to routine, who has reached the stage at which the varieties of school experience seem to have exhausted themselves, the really serious struggle with the teaching life is beginning. If no effort is made the result easily may be that unimaginative process which is effective in producing examination results, but which inevitably destroys the educative and suggestive value of the subject. Where the teaching of such a subject as history, dealing with important factors of life and social progress, is concerned, it is of importance that it should not be entrusted to teachers who succumb to the influences of routine. $^{1}$ At all cost it must be taken away from those who refuse to undergo the stern discipline of form that the handling of important topics demands, at all cost it must be removed from the control of those who think that "it is the teacher who must generalise from and analyse facts." Teachers must be found who, guided by instinct or professional training, have learned to keep the presentation of their subject under continual

1 For some years to come the teacher of history will undoubtedly have much to struggle against. He may at any time find himself working under a headmaster whose one idea is results in examination, or may have to prepare for inspection by an inspector who is unable to see farther than the "set-piece" lesson which can so easily be produced, but to the detriment of more subtle work. 
control and to introduce the element of form when the subject-matter tends to be too attractive or too discursive, who realise that frequently their aim should be to make the work harder rather than easier for their pupils, that the road of rapid and superficial inference leads to mental sluggishness, and the way of careless judgment to moral weakness. As compared with the claims of history to be a leading subject in the curriculum, the arguments in favour of "linguistic" read like special pleading, but the validity of these claims depends on the efforts of teachers who have learned to treat their subject in accordance with the dictates of method. 


\section{INDEX}

Accuracy, criteria of, 3 I

Aristotle, 1 10

Associationist psychology, I 13

Ballads, a mode of using, 208

Battles, conciliation of discrepant accounts of, $67-78$

Bernheim, E., 25

\section{Calkins, $M . W_{\text {., }}$ I12}

Character, analysis of, 55, 56-6r, 107, 136,137

Chronology, $13^{8}$

Clarendon, Constitutions of, 123

Concreteness, rzo sqq.

Contrariant Ideas, I 18

Data of history, 28

Documents, method of using, 40 $s q q$.

as atmosphere, 96, 104

Evidence, introduction to treatment of, 215

Examinations, conditions of good, I 7 I

Examination papers criticised, 173 sqg.

variation of suggested, 182

Fletcher, C. R. L., I7

Form in teaching, need of, 229

Formal element in history, I 7

Formal training, 33

Fouille, $A_{\text {., }} 27$

Genealogies, treatment of, 143 sqq.
Hassall, A., 17

Herbartianism, 39, I I 3

Internal evidence, interpretation of, $4 \pi$

Jaeger, Dr. Oscar, $3^{6}$

Kant, IxI

Laboratory, historical, 93

Lamprecht, $K ., 3^{2}$

Langlois, Ch. v., 32

Letters, value as evidence, 66 , 100

Libraries, class-room, 219

Line of time, use of, 132, 140, 14 I

Local history, 320

Locke, ro, xio

Magna Charta, 124

Marten, C. H. K., 18

Mayor, A. B., 18

Method, need of, 227

Modern reference of history, 215

Moral training through history, I05

Mortmain, statute of, I I I

Natorp, $P$., II5

Natural science, value of, to individual, 34

Notebooks, use of, by boys, $\times 34$

Outlines v. Periods, ${ }_{53}$

Personal detail, importance of, $x_{30}$

Portraits, value of, $x_{50}$ 
Poetry, in the history lcsson, 189 difficultics in the use of, 190 limited choice of, 192 by modern writers, 201 method of using, 204

Religious legislation, treatment of, I27

School subjects, conditions of manipulation of, 2

Seignobos, 28, 30, 32

Sigrvart, 35

Sincerity, criteria of, 3 I

Sociology, 26

Soft options, 22
Source-books, 40, 94 composition of, 93

Special periods, need for emphasising, 162

Statutes, analysis of, 79

Syllabuses of history, German and French, 155 sqq.

Text-book, use of, 37,40

Value of history, 4, 35

Views on history ofDr. Arnold, 13

Renaissance writers, 8-I2 Rollin, $\mathbf{3}$ 


\section{BY THE SAME AUTHOR.}

\section{SUGGESTION IN EDUCATION}

Second Edition. Large Crown 8vo. Cloth.

Price 45. 6d. net. (By Post, 4s. rod.)

SOME PRESS OPINIONS

Education. - "We regard Mr. Keatinge's work as one of the most valuable contribu. tions to educational science which have been published during recent years. . . . It is a fascinating work, calculated to interest the thoughtful parent as well as the professional reader."

Bookman.- "The book is one of the most refreshing and stimulating that has appeared for a long time."

Aberdeen Free Press. - "The whole book is 'suggestive' in the true sense. . . . It is one of the best books on education that we have seen for a long time."

Manchester Guardiar. - "A very successful attempt to show how the fruits of psychological inquiry .... can be employed to elucidate the practice of education. A work of real importance which will challenge careful attention from students of education."

Educational Nezws. - "We strongly recommend teachers who wish a new light on many of the problems they are tackling every day to procure a copy of this masterly and interesting work and read it for themselves. It will amply repay a careful study."

\section{THE GREAT DIDACTIC OF JOHN AMOS COMENIUS}

\section{SETTING FORTH THE WHOLE ART OF TEACHING ALL THINGS TO ALL MEN}

FOR THE FIRST TIME ENGLISHED

Second Edition. Large Crown 8vo. Cloth.

Price 7s. 6d. net. (By Post, 7s. IId.)

The work can also be had in two separate volumes, vis.

PART I. INTRODUCTIONS. Price 3s. 6d. net. (By Post, 3s. rod.) PART II. TEXT . . . Price 4s. 6d. net. (By Post, 4s. rod.)

\section{OPINIONS OF THE PRESS}

Times.-" Mr. Keatinge's Translation of the 'Great Didactic' is vigorously executed ; his biography of its author is at once copious, judicious, and sympathetic, and his sketch of the history of education and of Comenius's place in it is eminently scholarly and instructive."

Guardian.- "A learned and scholarly translation with every historical illustration and addition that could possibly be desired. . . . The book is an extremely careful, industrious, and learned piece of work."

The Academy. - "Very completely, in many ways, has Mr. Keatinge done his work. The biographical treatment is full : it is claimed with justification that it is fuller than any other account in English. The historical introduction embodies much patient research, and brings forward a mass of information concerning early English schoolbooks not easily accessible."

PUBLISHED BY A. \& C. BLACK, 4,5 , \& 6 SOHO SQUARE, LONDON, w. 
By M. W. KEATINGE, M.A., AND N. L. FRAZER, M.A, HEADMASTER OF BATLEY GRAMMAR SCHOOL.

\title{
A HISTORY OF ENGLAND FOR SCHOOLS
}

\author{
WITH DOCUMENTS, PROBLEMS, AND EXERCISES
}

In one Volume, 730 pages, containing 29 Maps, Plans, and Illustrations. Large Crown 8 vo. Cloth, Price 5S. ; or in two Volumes, Cloth, Price 2S. 6d. each.

\section{SECOND EDITION}

Volume I.

Historical Narrative 55 B.C. to 1603 A.D.

Genealogies, Documents, Problems, and

Exercises, also Index.

\section{Volume II.}

Historical Narrative I6n3 to Igoo.

Genealogies, Documents, Problems, and Exercises, also Index.

FROM THE PREFACE

This book has been written in response to a demand from a number of history teachers and inspectors of Schools who were anxious to see history taught on the lines suggested in Studies in the Teaching of History but could find no text-book suitable for class use.

\section{SOME PRESS OPINIONS}

Times.- " A gallant and successful effort to solve a difficult problem and to introduce a real and great improvement into the teaching of history."

Athenaum. - "This admirable little book ... an excellent piece of work."

Educational News. - "We would again recommend all who teach History to see these volumes."

\section{DOCUMENTS \\ OF BRITISH HISTORY}

\section{WITH PROBLEMS AND EXERCISES}

Sections I.-V. reprinted from $A$ History of England for Schools.

In one Volume. Large Crown 8vo. Cloth. Price 35. 6d.

Or in six Sections. Limp Cloth. Price 8d. each.
I. A.D. $78-1216$.
II. A.D. $1216-1399$
III. A.D. $1399-1603$.
IV. A.D. $1603^{-17} 75$
V. A.D. $1715-1815$.
VI. A.D. $1815-1900$

Lordon Teacher.-. "Extremely useful for class work in history."

Athenaum. - "Should improve the teaching of history."

\section{INTRODUCTION TO WORLD HISTORY}

In one Volume, Large Crown 8vo, Cloth, 288 pages, with 21 Maps and 23 Illustrations. Price 25.

Scotsman.- "It is a skilful and well-proportioned sketch of a large subject, well devised to meet the needs of school teachers who wish a ready means of imparting the timeperspective of the events of universal history. Its narrative is simple, concise, and interesting, and well supplied with maps and illustrations."

London Teacher.- "It would be hardly possible, however, to have two more competent or experienced collaborators, and we have no doubt that this volume will be very heartily welcomed in both elementary and secondary schools."

PUBLISHED BY A. \& C. BLACK, 4, 5, \& 6 SOHO SQUARE, LONDON, W. 

University of Callifomia

SOUTHERN REGIONAL LIBRARY FACILITY

405 Hilgard Avenue, Los Angeles, CA 90024-1388

Retum this material to the library

from which it was borrowed.

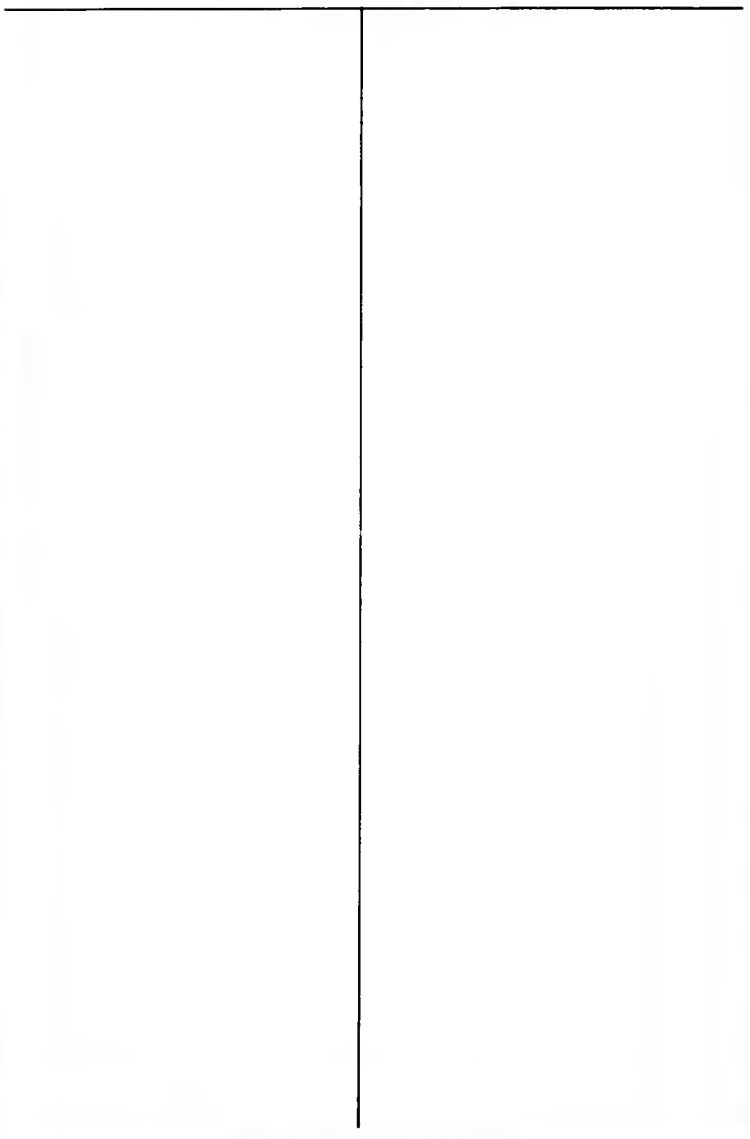


UC SOUTHERN REGIONAL LIBRARY FACILITY

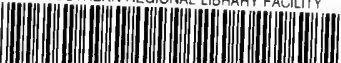

A 000687528 
